Universidade de São Paulo

Instituto de Física de São Carlos

Mariana Raquel Bunoro Batista

\title{
Mobilidade da hélice 12 de receptores nucleares: comparação entre simulações de dinâmica molecular e experimentos de anisotropia de fluorescência
}



Mariana Raquel Bunoro Batista

\section{Mobilidade da hélice 12 de receptores nucleares: comparação entre simulações de dinâmica molecular e experimentos de anisotropia de fluorescência}

Dissertação apresentada ao Programa de PósGraduação em Física do Instituto de Física de São Carlos da Universidade de São Paulo, para obtenção do título de Mestre em Ciências.

Área de Concentração: Física Aplicada

Orientador: Prof. Dr. Leandro Martínez

Versão Corrigida

(versão original disponível na Unidade que aloja o Programa)

São Carlos 
AUTORIZO A REPRODUÇÃO E DIVULGAÇÃO TOTAL OU PARCIAL DESTE TRABALHO, POR QUALQUER MEIO CONVENCIONAL OU ELETRÔNICO, PARA FINS DE ESTUDO E PESQUISA, DESDE QUE CITADA A FONTE.

Ficha catalográfica elaborada pelo Serviço de Biblioteca e Informação do IFSC, com os dados fornecidos pelo(a) autor(a)

Bunoro Batista, Mariana Raquel

Mobilidade da hélice 12 de receptores nucleares: comparação entre simulações de dinâmica molecular e experimentos de anisotropia de fluorescência / Mariana Raquel Bunoro Batista; orientador Leandro Martínez - versão corrigida -- São Carlos, 2013. $93 \mathrm{p}$.

Dissertação (Mestrado - Programa de Pós-Graduação em Física Aplicada) -- Instituto de Física de São Carlos, Universidade de São Paulo, 2013.

1. Receptores nucleares. 2. Dinâmica molecular. 3. Hélice 12. 4. Anisotropia de fluorescência. 5. LBD. I. Martínez, Leandro, orient. II. Título. 




\section{AGRADECIMENTOS}

- Aos meus pais, Marta e João e ao meu irmão, João Luiz, pelos ensinamentos, apoio e suporte durante meus quatro anos de graduação e dois anos de mestrado em São Carlos.

- Ao Leandro, que mesmo estando distante nos últimos meses, sempre esteve muito presente. Agradeço por toda paciência, dedicação e principalmente, pelos conhecimentos e experiências transmitidas.

- Às minhas amigas de graduação, Ana Paula (Coró), Jaqueline (Ling) e Thaís que sempre estiveram muito presentes me motivando e me apoiando. Agradeço também por vocês terem me proporcionado tantos momentos de diversão e descontração.

- Às minhas amigas de Cuiabá, Luma e Isa, que sempre me receberam com muito carinho nas férias.

- Ao Daniel, um amigo mais recente, mas que foi muito importante durante meu período de "crise de mestrado". Agradeço também por me socorrer nos meus problemas com Latex.

- Aos meus colegas de sala e de grupo, Heloisa e Luciano, pela companhia durante o mestrado e ao professor Alessandro, sempre disposto a contribuir.

- Aos funcionários do IFSC, especialmente, aos funcionários da secretaria de Pós Graduação, da biblioteca e da gráfica, sempre muito prestativos e dispostos a atender nossos pedidos prontamente.

- À FAPESP e ao CNPQ pelo financiamento. 

Antes que você possa alcançar o topo de uma árvore e entender os brotos e as flores, você terá de ir fundo nas raízes, porque o segredo está lá. 



\section{RESUMO}

BATISTA, M. R. B. Mobilidade da hélice 12 de receptores nucleares: comparação entre simulações de dinâmica molecular e experimentos de anisotropia de fluorescência. 2013. 93 p. Dissertação (Mestrado em Ciências) - Instituto de Física de São Carlos, Universidade de São Paulo, São Carlos, 2013.

Receptores nucleares formam uma superfamília de proteínas responsáveis pela regulação da expressão de genes. Estruturalmente, são formados por três domínios: um domínio N-terminal bastante variável, um domínio altamente conservado de ligação com o DNA e um domínio C-terminal, menos conservado, denominado domínio de ligação com o ligante (LDB). Diversos experimentos mostram que a interação com o ligante afeta a estrutura e a mobilidade da hélice C-terminal dos receptores nucleares (hélice 12 do domínio de ligação com o ligante), sendo o principal mecanismo de ativação e repressão da transcrição. As primeiras estruturas de LBDs de receptores nucleares revelaram importantes diferenças entre estruturas contendo ligantes (holo) e estruturas apo, principalmente no que diz respeito a posição da hélice 12: em estruturas apo, foi observada a H12 em uma conformação aberta, expondo o sítio de ligação com o ligante, enquanto que em estruturas holo, foi observada a H12 em uma conformação fechada, dobrada sobre o corpo do LBD e envolvendo completamente o ligante. Essa diferença sugeriu um mecanismo para a entrada e saída de ligantes do sítio de ligação denominado "modelo da ratoeira", entretanto, esse modelo apresenta diversas inconsistências e tem sido desacreditado. Estudos experimentais e teóricos recentes mostram que a hélice 12 é mais móvel na ausência de ligantes, entretanto, esses estudos não fornecem evidencias de que o aumento da mobilidade da está associado com o deslocamento da $\mathrm{H} 12$ em relação ao corpo do LBD, como sugerido pelo modelo da ratoeira. Embora esteja claro que a hélice 12 é mais móvel na ausência de ligantes, a dimensão da variação conformacional sofrida pela hélice 12 ainda não está clara. Nesse trabalho buscamos a construção de um modelo capaz de dimensionar a mobilidade da hélice 12 através da comparação direta entre simulações de dinâmica molecular e experimentos de anisotropia de fluorescência resolvida no tempo. Utilizando simulações de dinâmica molecular 
reproduzimos experimentos de anisotropia de fluorescência acoplando a sonda cys-fluor à hélice 12 do PPAR $\gamma$ para estudar sua mobilidade. Mostramos que as observações experimentais só podem ser explicadas por conformações onde a sonda fluorescente permanece presa a superfície do LBD. Foi mostrado também que curvas de anisotropia com decaimentos comparáveis com os decaimentos experimentais estão associados à pequenas variações conformacionais de hélice 12. Simulações para dois modelos de apo-PPAR $\gamma$ com a H12 aberta em relação ao corpo do LBD e para as estruturas cristalográficas de apo-RXR e apo-ER, onde a H12 também adota uma conformação aberta, revelaram curvas de anisotropia com decaimentos mais rápidos que os experimentais. Esses resultados implicam em um modelo onde a $\mathrm{H} 12$ sofre alterações conformacionais locais, não apresentando variações tão dramáticas como o proposto pelo modelo da ratoeira.

PAlavras-Chave: Receptores nucleares. Dinâmica molecular. Hélice 12. Anisotropia de fluorescência. LBD. 


\section{ABSTRACT}

BATISTA, M. R. B. Nucler receptor's helix 12 mobility: comparison between molecular dynamics simulations and fluorescence anisotropy experiments. 2013. 93 p. Dissertação (Mestrado em Ciências) - Instituto de Física de São Carlos, Universidade de São Paulo, São Carlos, 2013.

Nuclear Hormone Receptors comprise a protein superfamily responsible for regulation of gene expression. Structurally, they are composed by three domains: a variable N-terminal domain, a highly conserved DNA-binding domain (DBD), and a less conserved C-terminal domain, known as ligand binding domain (LBD). Many experiments have shown that the interaction with ligands affects the structure and the mobility of nuclear receptor's C-terminal helix (LBDs Helix 12), being the main mechanism of transcription activation and repression. The first nuclear receptor LBDs structures revealed important differences between ligand bound (holo) and apo-structures concerning the position of the H12: in apo structures, $\mathrm{H} 12$ adopted an open conformation, exposing the ligand binding pocket, whereas in holo structures, the $\mathrm{H} 12$ was closed, packed over the body of the LBD, burying completely the ligand. This difference suggested a mechanism for ligand entry and exit from the binding pocket called "mouse-trap model", however this model has several inconsistencies and has been discredited. Recent experimental and theoretical studies have shown that $\mathrm{H} 12$ is more labile in the absence of ligand, but these studies don't provide evidences that the increase in the mobility is associated with the detachment of $\mathrm{H} 12$ from the body of the LBD as suggested by the mouse-trap model. Although it's clear that H12 is more flexible in the absence of ligands, the size of the conformational changes undergone by $\mathrm{H} 12$ is not yet clear. In this work we seek to construct a definitive model for the range of motions that $\mathrm{H} 12$ may undergo in the presence or absence of ligand using molecular dynamics simulations. Through direct comparison between molecular dynamics simulations and time-resolved fluorescence anisotropy experiments, we show that experimental observation can only be explained by conformations where the fluorescent probe is interacting with the surface of the PPAR $\gamma$ surface. We also show that simulations with anisotropy decay rates comparable to the experimental decay are associated with small helix 
12 conformational changes. Simulations with two models of apo-PPAR $\gamma$ with $\mathrm{H} 12$ detached from the body of the LBD and with crystallographic structures of apo-RXR and apo-ER, where the $\mathrm{H} 12$ also is in an open conformation, display anisotropy decay rates significantly faster than the experimental ones. These results imply a model for the molecular mobility of the LBD where $\mathrm{H} 12$ undergoes local conformational changes and should exhibit dynamic properties less dramatic than proposed by the mouse trap model.

KEywords: Nuclear Hormone Receptor. Molecular dynamics. Helix 12. Fluoerescence anisotropy. LBD. 


\section{LISTA DE FIGURAS}

1.1 Mecanismo de ação dos receptores nucleares

1.2 Representacão esquemática dos domínios estruturais dos receptores nucleares e suas funções. . . . . . . . . . . . . . . . . . . . . . . . . . . . p. 27

1.3 Estrutura do DBD do receptor de estrógeno . . . . . . . . . . . . . . . p. 29

1.4 Estrutura do LDB do receptor do ácido retinóico. O LBD forma um "sanduíche". Em azul, verde e roxo estão mostradas as hélices dos três planos. A hélice 12 está em vermelho (PDB: 2LBD) (13) . . . . . . . . . . . . . . . . p. 30

1.5 Estrutura cristalográfica do PPAR $\alpha$ ligado ao (a) coativador (PDB: $1 \mathrm{~K} 7 \mathrm{~L}$ ) e ao (b) correpressor (PDB: $1 K K Q)$. A hélice 12 está representada em amarelo e os peptídeos correguladores em roxo. Destaque para a posição da $\mathrm{H} 12$ nas duas estruturas e para a extensão N-terminal do corregulador (11, 12). . .

1.6 Estrutura cristalográfica do LBD do (a) apo-RXR $\alpha$ (PDB: 1LBD) e (b) $\mathrm{RAR} \gamma$ ligado ao ácido retinóico (PDB: 2LBD). Destaque para a mudança conformacional da hélice 12 observada entre as duas estruturas (13, 14). .

1.7 Caminhos de dissociação do ligante em TR: (a) Caminho I: saída do ligante se dá através de uma abertura originada pelo deslocamento da H12. Esse caminho assemelha-se ao mecanismo da "ratoeira" (b) Caminho II: o ligante se dissocia através da separação formada entre a H8 e a H11. (c) Caminho III: a H3 é quebrada em duas partes e a movimentação da folha $\beta$ abre uma cavidade por onde o ligante escapa. Os dois últimos mecanismos não contradizem a associação com cofatores. Reproduzido de (21). . . . . . . .

2.1 Estrutura do heterodímero de PPPAR $\gamma$ e RXR $\alpha$ sobre o DNA (PDB: 3DZY). Em lilás está representada a estrutura do $\operatorname{PPAR} \gamma$, em azul do $\operatorname{RX} R \alpha$, em vermelho dos peptídeos coativadores e em cinza os íons de Zinco. Na parte superior, são observados os LBDs e na inferior os DBDs (28). . . . . . . . . 
2.2 Estrutura do LBD do receptor PPAR $\gamma$ (PDB: 2PRG). Destaque para a cavidade de ligação com o ligante na forma de $Y(18)$. . . . . . . . . . . . . .

2.3 (a) Superposição de agonistas de PPAR $\gamma$ no seu LBD: em laranja estão representados os agonistas totais e em azul os agonistas parciais. (Agonistas totais: PBD 2PRG (18), 1FM9 (29), 2ATH, 2I4J (30), 2Q59 (30) e 3B3K (33). Agonistas parciais: 4PRG (34), 2Q5P (30), 2Q5S, 2Q6R (30), 2Q61 (30) e 3D6D (33))(b) Ampliação do sitio de ligação na presença de agonistas totais: é possível perceber a proximidade de todos ligantes com a Try473, formando interações de hidrogênio que estabilizam a H12 na sua conformação ativa. (c) Interação entre os resíduos da cavidade de ligação com o ligante e a rosiglitazona, um agonista total. (d) Ampliação do sitio de ligação com o ligante na presença de agonistas parciais: esses ligantes ocupam uma região alternativa, não interagindo diretamente com a hélice 12. Adaptado de (31).

3.1 Esquema mostrando os termos utilizados para modelar as interações entre átomos ligados covalentemente: (a) estiramento das ligações químicas, (b) deformação angular entre átomos ligados sucessivamente e (c) torções diedrais associadas a quatro átomos ligados sucessivamente.

3.2 Representação gráfica dos potenciais de Lennard-Jones e de Coulomb. Enquanto o potencial de Coulomb decai lentamente, o potencial de LennardJonnes é de curto alcance e tem a forma de um poço de potecial por ser formado pela combinação de $u$ termo repulsivo com outro atrativo.

4.1 (a) Estrutura do LBD de PPAR $\gamma$. As mutações localizadas em Val290 e Pro467 estão destacadas em amarelo; em vermelho está mostrada a hélice 12. (b) Estrutura da molécula fluorescente, cys-fluor, utilizada nos experimentos de anisotropia de fluorescência. (c) Visão esquemática do domínio de ligação com o ligante ilustrando os movimentos que podem ser observados através de medidas de anisotropia de fluorescência resolvida no tempo. Adaptado

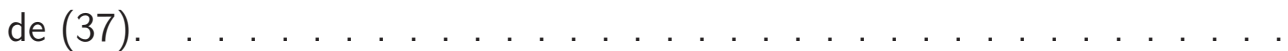

4.2 (a) Sistema utilizado para estudar a difusão rotacional da sonda fluorescente cys-fluor. (b) Curvas de decaimento da anisotropia de fluorescência: em cinza estão representadas as curvas obtidas para cada simulação, usando $\gamma=10 \mathrm{ps}^{-1}$ e acoplando o banho térmico a todo sistema, e em vermelho, a curva de anisotropia média. 
4.3 Sobreposicão de algumas configurações iniciais utilizadas nas simulações de dinâmica molecular.

4.4 Dependência temporal da anisotropia. Em cinza estão representadas as curvas de decaimento da anisotropria obtidas a partir de cada configuração inicial. Os decaimentos obtidos experimentalmente para holo-PPAR $\gamma$ e apoPPAR $\gamma$ estão representados em azul e vermelho, respectivamente (37). . .

4.5 (a) Esquema mostrando a menor distância entre o oxigênio do anel central do cys-fluor e a superfície do LBD. (\$) Distribuição da menor distância entre o oxigênio central do cysfluor e a superfície do LBD para quatro simulações. As quatro simulações escolhidas correspondem às curvas de anisotropia destacadas em cores no gráfico interno.

4.6 Superposicão das conformações adotadas pelo cys-fluor nas simulações 1 (a), 2 (b), 3 (c) e 4 (d) . . . . . . . . . . . . . . . . . . . . .

4.7 Evolução temporal do RMSD da hélice 12 em relação à posição inicial. . .

4.8 Comparacão entre a conformacão inicial e a conformação associada ao maior valor de RMSD para as simulações 1 (a) e 4 (b) . . . . . . . . . . . . . . . . .

4.9 Máxima variacão conformacional adotada pela hélice 12 para as oito simulações com curvas de anisotropia mais similares à experimental. . . . . . .

5.1 (a) SMD com velocidade constante em uma dimensão. Em vermelho está representado o átomo virtual e en azul o átomo SMD. A medida que o átomo virtual se move com velocidade constante, o átomo SMD experimenta uma força que depende linearmente da separação entre os dois átomos. (b) Sobreposição da conformação addtada pela H12 no inicio (vermelho) e no final (azul) da simulação de SMD.

5.2 Estruturas para apo-PPAR $\gamma$ com a H12 aberta obtidas a partir de simulações de SMD.

5.3 Comparação entre as curvas de anisotropia para o PPAR $\gamma$ : em cinza estão representadas as 35 curvas obtidas para o holo-PPAR $\gamma$ nativo, em laranja as 10 curvas para os modelos de apo-PPAR $\gamma$ com a H12 aberta; em azul e vermelho as curvas experimentais para o PPAR $\gamma$ na presença e na ausência de ligante, respectivamente. 
5.4 Sobreposição de algumas conformações adotadas pela molécula de cys-fluor na simulação correspondente a curva de anisotropia com o decaimento mais lento (a) e com decaimento mais rápido (b) para o modelo de PPAR $\gamma$ com a $\mathrm{H} 12$ aberta. . . . . . . . . . . . . . . . . . . . . . . . . . . . p. 81

5.5 Evolucão temporal do RMSD da hélice 12 para as simulações com decaimento mais rápido (vermelho) e mais lento (preto) . . . . . . . . . . . p. 81

5.6 Estruturas cristalográficas de receptores nucleares com a hélice 12 aberta utilizados para estudar o decaimento da anisotropia de fluorescência: (a) estrutura do Receptor do Ácido Retinóico (PDB: 1LBD) e (b) estrutura do Receptor de Estrógeno (PDB: 1A52) . . . . . . . . . . . . . . . . . . . . . p. 82

5.7 Curvas de anisotropia para o cysfluor acoplado a H12 do ER (a) e do RXR (b) . . . . . . . . . . . . . . . . . . . . . . . . p. 83

5.8 Conformação adotada pelo cys-fluor em uma simulação para RXR onde é possivel a interação da sonda com a superfície do LBD, resultando em uma curva de anisotropia com decaimento lento. . . . . . . . . . . . . . . . p. p 84

5.9 Evolução temporal do RMSD da hélice 12 em relação a posição inicial para os modelos com a $\mathrm{H} 12$ aberta. . . . . . . . . . . . . . . . . p. 85

5.10 Máxima variação conformacional sofrida pela hélice 12 do $\operatorname{PPAR} \gamma(\mathrm{a}), \operatorname{ER}$ (b) e RXR (c) . . . . . . . . . . . . . . . . . . . . . . . . . . . . p. 85 


\section{LISTA DE TABELAS}

4.1 Sistemas simulados . . . . . . . . . . . . . . . . . . . . . . . p. 64

4.2 Energia de interação entre o resíduo Tyr473 e a Rosiglitazona . . . . . . . p. 73 



\section{Lista de abreviaturas e siglas}

BRL Roziglitazona

CTE Extensão C-terminal

DBD DNA binding domain

DNA Ácido desoxirrinonucleico

ER Receptor de estrógeno

FEP Free Energy Perturbation

FFA Free fatty acids

HRE Hormone response elements

HSP Heat shock protein

LBD Ligand binding domain

LBP Ligand binding pocket

PDB Protein Data Bank

PME Particle Mesh Ewald

PPAR Receptor ativado por proliferadores de peroxissomos

RAR Receptor do ácido retinóico

RDF Radial distribuction function

RMN Ressonância Magnética Nuclear

RMSD Root mean squared deviation

RN Receptores nucleares 
RXR Receptor do ácido X retinóico

SMD Steered Molecular Dynamics

TCF Time correlation function

TR Receptor do hormônio da tireóide

TZD Tiazolidinediona

VDR Receptor de vitamina D 


\section{SUMÁRIO}

1 Receptores Nucleares

p. 25

1.1 Mecanismo de ação . . . . . . . . . . . . . . . . . p. 26

1.2 Estrutura e Funcão . . . . . . . . . . . . . . . . . . . . . . . p. 27

1.2 .1 A região $A / B \quad \ldots \ldots \ldots$ p. 27

1.2 .2 O domínio de ligação com o DNA . . . . . . . . . . . . . . . p. 28

1.2.3 O domínio de ligação com o ligante . . . . . . . . . . . . . . . . . $\quad$ p. 28

1.2 .4 correguladores . . . . . . . . . . . . . . . . . . . . . . . . . p. 29

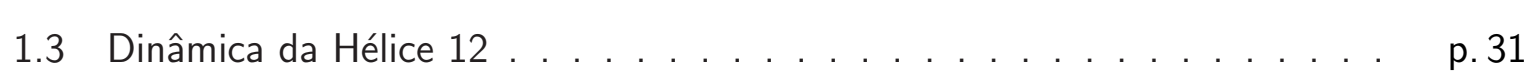

1.3.1 Mecanismos de dissociação de ligantes . . . . . . . . . . . . . p. 34

2 Receptores ativados por proliferadores de peroxissomos - O PPAR $\quad$ p. 37

2.1 Funções biológicas do PPAR $\ldots \ldots \ldots$. . . . . . . . . . . . . . . . . . . . . . . .

2.2 Estrutura do PPAR $\ldots \ldots \ldots \ldots \ldots$. . . . . . . . . . . . . . . . . . . . . . . .

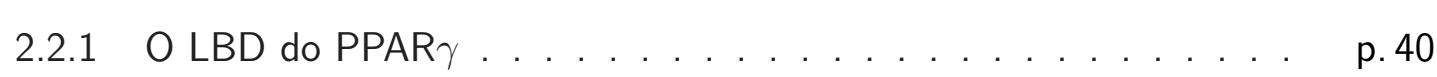

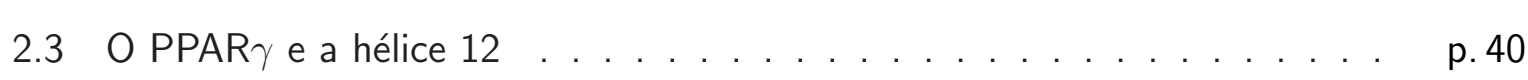

2.3 .1 Mecanismos de ativação . . . . . . . . . . . . . . . . . . . p. 41

2.3.2 Aspectos dinâmicos do LDB de PPAR . . . . . . . . . . . . . . . p. 42

3 Simulações de Dinâmica Molecular $\quad$ p. 45

3.1 Potenciais de interação . . . . . . . . . . . . . . . . p. 46

3.2 Configurações e velocidades iniciais . . . . . . . . . . . . . . . . p. 49 
3.3 Equações de movimento . . . . . . . . . . . . . . . . . . . . p. 50

3.4 Ensembles . . . . . . . . . . . . . . . . . . . . . . . . . . . . . p p. 52

3.4.1 Controle da Temperatura . . . . . . . . . . . . . . p. 53

3.4 .2 Controle da Pressão . . . . . . . . . . . . . . . . . . . . . . p. 54

3.5 Etapas envolvidas na simulação $\ldots \ldots \ldots$. . . . . . . . . . . . . . . 54

3.5.1 Minimização . . . . . . . . . . . . . . . . . . . . p. 54

3.5.2 Simulação . . . . . . . . . . . . . . . . . . . . p. . . . 55

4 Dinâmica de hélice 12 do PPAR 1

4.1 Anisotropia de fluorescência . . . . . . . . . . . . . . . . . p. 57

4.1.1 Estudos de anisotropia de fluorescência para o PPAR . . . . . . . p. 59

4.2 Anisotropia de fluorescência para o cys-fluor livre em água . . . . . . . . . p. 61

4.2 .1 Simulações de dinâmica molecular . . . . . . . . . . . . . . . . . p. 61

4.2 .2 Resultados . . . . . . . . . . . . . . . . . . . . . . . p. 63

4.3 Anisotropia de fluorescência do complexo holo-PPAR $\gamma$-cysfluon . . . . . . . p 64

4.3.1 Detalhes das simulações . . . . . . . . . . . . . . . . . p. 65

4.3.1.1 Configurações iniciais . . . . . . . . . . . . . p. 65

4.3.1.2 Preparação dos sistemas e simulações produtivas . . . . . p. 66

4.3.2 Resultados . . . . . . . . . . . . . . . . . . . . p. 67

4.3.2.1 Variação conformacional da hélice 12 . . . . . . . . p. 70

4.4 Conclusões $\ldots \ldots \ldots \ldots$. . . . . . . . . . . . . . . . . . . . . . . . . . . . . . .

5 Receptores Nucleares com a hélice 12 aberta $\quad$ p. 77

5.1 Modelos de PPAR $\gamma$ com a hélice 12 aberta . . . . . . . . . . . . . . . . . $\quad$ p.77

5.1 .1 Steered Molecular Dynamics . . . . . . . . . . . . . . . . p. 77

5.1.2 Anisotropia de fluorescência para o apo-PPAR $\gamma$ com a H12 aberta . p. 79

5.2 Outros modelos de receptores nucleares com hélice 12 aberta . . . . . . p p. 82

5.3 Mobilidade da hélice $12 \ldots \ldots \ldots$. . . . . . . . . . . . . . . . . . . . . . 84 
5.4 Conclusões $\ldots \ldots \ldots \ldots \ldots \ldots$. . . . . . . . . . . . . . . . . . . . . . . . . . .

6 Conclusões finais $\quad$ p. 87

$\begin{array}{ll}\text { REFERÊNCIAS } & \text { p. } 89\end{array}$ 



\section{CAPÍTULO 1}

\section{Receptores Nucleares}

Receptores nucleares (RN) formam uma superfamília de proteínas responsáveis pela regulação da transcrição de genes relacionados a diversos aspectos de desenvolvimento, diferenciação, reprodução e homeostase em eucariotos. A regulação da transcrição, para a maioria dos receptores nucleares se dá através da ligação de pequenas moléculas, como hormônios ou ácidos graxos, a um dos domínios do receptor.

No genoma humano são conhecidos 48 receptores. Embora todas as proteínas dessa superfamília tenham a função de regular a transcrição de genes, estas são tipicamente divididas em três famílias ou classes de acordo com seu mecanismo de ação (1). A classe I (receptores esteroidais) inclui os receptores de estrógeno (ER), de progesterona (PR), de glicocorticoides (GR) e de mineralocorticoides. A classe II é formada por receptores que atuam na forma de heterodímeros. Pertencem a essa classe os receptores de hormônio tireoidiano (TR), de vitamina $\mathrm{D}(\mathrm{VDR})$, do ácido retinóico (RAR) e o receptor ativado por proliferadores de peroxissomos (PPAR). A terceira classes de receptores são os receptores órfãos que podem atuar na forma de dímeros ou monômeros. Estes foram assim denominados quando descobertos pois não tiveram seus ligantes endógenos identificados. Recentemente, alguns desses ligantes de receptores órfãos foram identificados, como é o caso dos ácidos biliares (1).

Devido a sua grande diversidade e seu relevante papel biológico, receptores nucleares tornam-se alvos interessantes para o desenvolvimento de novos fármacos. Além disso, disfunções no mecanismo de sinalização de determinados receptores estão associadas a diversas doenças humanas, por exemplo, RARs estão associados a diferentes tipos de leucemia, ER com o crescimento de câncer de mama e os PPARs com doenças metabólicas como a diabetes do tipo II (2-3). 


\subsection{Mecanismo de ação}

Embora todos receptores nucleares apresentem funções similares, existem diferenças bioquímicas no seu mecanismo de ação dependendo da sua classe, como mostrado na figura 1.1. Os receptores da classe I (família dos receptores esteroidais) encontram-se no citoplasma celular associados as heat shock proteins (HSP), incluindo as hsp90 e hsp70. Quando o ligante se liga ao receptor, ainda no citoplasma, o complexo receptor-HSP é desfeito e o receptor migra para o núcleo, onde, na forma de homodímeros, reconhece sequências específicas de DNA arranjadas na forma de palíndromos imperfeitos. Os receptores dessa classe reconhecem a sequência AGAACA, com exceção do ER que se liga a sequência AGGTCA. Uma vez ligado ao DNA, proteínas coativadoras podem ser recrutadas e a transcrição do gene-alvo é promovida (4-5).

Proteínas da classe II, diferente das receptores esteroidais, atuam na forma de heterodímeros. TR, PPAR, VDR e RAR associam-se ao receptor do ácido 9-cis retinóico e se ligam a sequências de DNA com repetições diretas com a forma AGGTCA. Os heterodímeros permanecem, mesmo na ausência de ligantes, associados ao DNA e à proteínas correguladoras. Na ausência do ligante específico, a transcrição é reprimida pela presença de proteínas correpressoras, entretanto, na presença do ligante, a associação com os correpressores é desfeita e proteínas coativadoras são recrutadas, ativando o processo de transcrição do gene alvo (5).

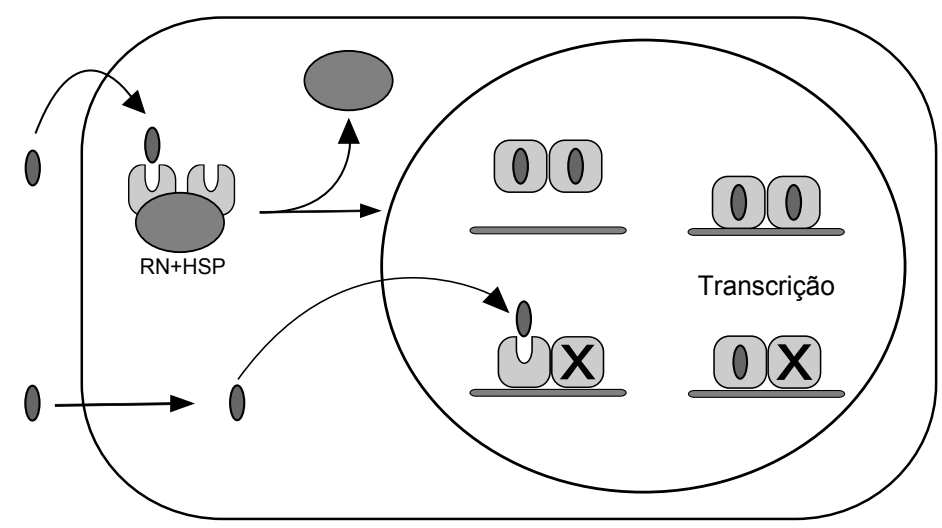

Figura 1.1 - Mecanismo geral dos receptores nucleares: os receptores podem estar localizados dentro ou fora do núcleo dependendo do seu mecanismo. Receptores da classe I localizamse no citoplasma associados as heat shock proteins. Na presença de ligante o complexo é desfeito e o receptor migra para o núcleo, onde na forma de homodímeros reconhece uma sequência específica de hexanucleotídeos. Receptores da classe II encontram-se no núcleo associados a uma determinada sequência de DNA, na forma de heterodímeros com o RXR. Na ausência de ligante, a transcrição é reprimida pela presença de proteínas correpressoras. Na presença do ligante específico, o mecanismo de transcrição é ativado. 


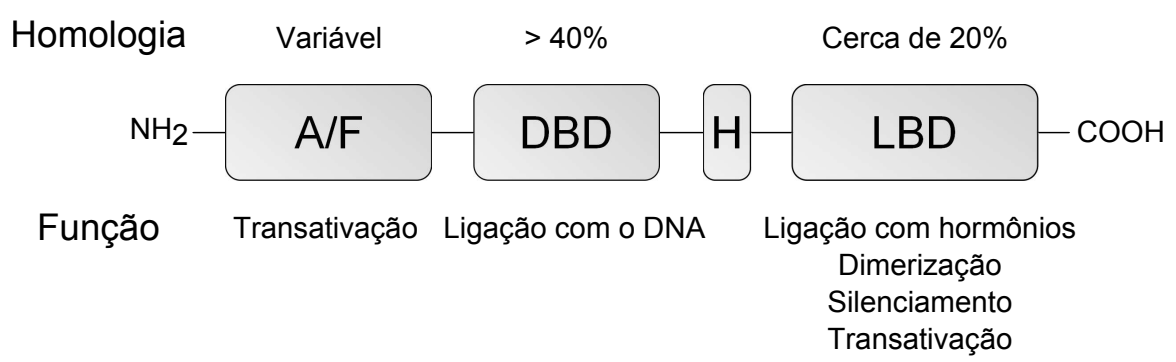

Figura 1.2 - Representação esquemática dos domínios estruturais dos receptores nucleares e suas funções.

O entendimento do mecanismo de ação para os receptores órfãos ainda não está bem estabelecido, entretanto, evidências mostram que estes podem atuar tanto da forma de monômeros quanto de heterodímeros com o RXR e reconhecem sequências de hexanucleotídeos similares as dos receptores da classe II (1).

\subsection{Estrutura e Função}

Receptores nucleares exibem uma estrutura modular com diferentes regiões correspondendo a domínios funcionais autônomos, os quais podem ser trocados entre receptores relacionados, sem perda de função. Tipicamente, um receptor nuclear é formado por três domínios: uma região variável $\mathrm{N}$-terminal, também denominada de região $\mathrm{A} / \mathrm{B}$, um domínio central altamente conservado, chamado de Domínio de ligação com o DNA (DBD, DNA binding domain) e uma porção C terminal denominado de domínio de ligação com o ligante (LBD, Ligand binding domain) $(4,6)$ Cada um desses domínios possui estrutura e função próprias e estão esquematizados na figura 1.2 .

\subsubsection{A região $A / B$}

Essa região é a mais variável em sequência e tamanho entre os membros da família dos receptores nucleares, por exemplo, contém 24 aminoácidos nos VDRs e 603 aminoácidos nos receptores mineralocorticoides (5). Esse domínio possui uma região ativadora de transcrição (AF-1) que atua independentemente da ligação com ligantes e forma interações diretas com outros domínios do receptor e com proteínas coativadoras, mas esse mecanismo de ativação 
ainda não está completamente estabelecido (4-5). Nenhuma estrutura do domínio N-terminal foi obtida; acredita-se que esse domínio seja desestruturado ou fracamente enovelado em solução, entretanto, estudos com receptores esteroidais mostram que a interação com outras proteínas ou com DNA pode induzir a formação de estruturas secundárias (1).

\subsubsection{O domínio de ligação com o DNA}

O Domínio de ligação com o DNA apresenta um alto grau de homologia dentro da superfamília dos receptores nucleares e é formado por aproximadamente 70 resíduos. Em cada DBD existem nove cisteínas conservadas, sendo oito delas responsáveis pela coordenação de dois íons de Zinco, $\mathrm{Zn}^{2+}$, em um arranjo tetraédrico, formando dois dedos de Zinco, estruturas típicas de proteínas que se ligam ao DNA. O primeiro dedo de Zinco possui uma região chamada de caixa-P (ou $P$-box), um conjunto de cinco aminoácidos responsáveis pelo reconhecimento de sequências específicas de DNA conhecidas como elementos de resposta dos hormônios (HRE, Hormone Response Elements). No segundo dedo de Zinco, existe outro conjunto de aminoácidos, chamado de caixa-D (ou $D$-box), responsável pela dimerização dos DBDs quando ligados ao DNA. Embora os DBDs apresentem função de dimerização, a estabilização dos dímeros é dependente da dimerização dos LBDs (6-7). O núcleo do DBD contém duas hélices $\alpha$, a primeira começando na terceira cisteína conservada e envolvendo o primeiro dedo de Zinco (hélice de reconhecimento). Esta hélice liga-se ao sulco maior do DNA, fazendo contato com bases específicas do HRE. A segunda hélice compreende o segundo dedo de Zinco e está disposta perpendicularmente a hélice de reconhecimento (4). A figura 1.3 mostra a estrutura do DBD de ER na forma de homodímero ligado ao DNA (? ).

\subsubsection{O domínio de ligação com o ligante}

O domínio de ligação com o ligante é o maior e mais complexo domínio dos receptores nucleares. A primeira estrutura cristalográfica foi obtida em 1995 para a forma apo * do receptor do ácido 9-cis retinóico (RXR). Desde então diversas estruturas foram resolvidas, revelando que, de forma geral, os LBDs são bastante similares (1). 


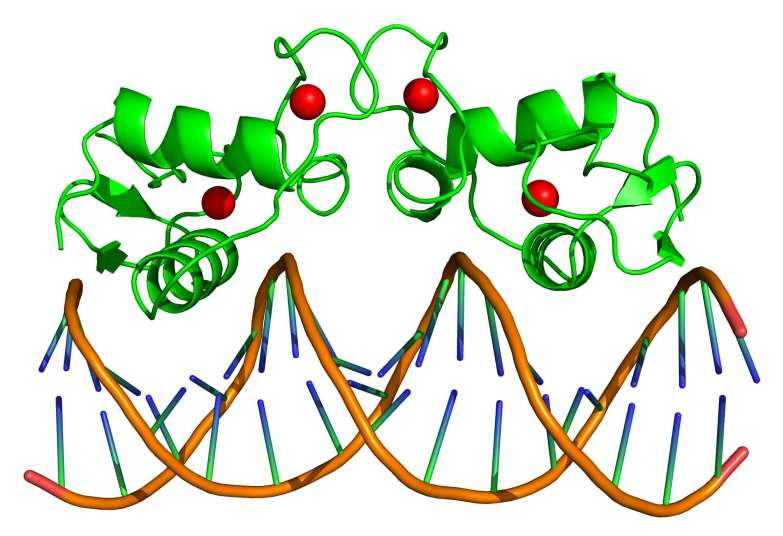

Figura 1.3 - Estrutura do domínio de ligação com o DNA do receptor de estrógeno. Os íons de zinco estão representados como esferas vermelhas (PDB: $1 H C Q)$ (6).

Os LBDs são domínios globulares formados, geralmente, por 12 hélices $\alpha$. Entretanto, existem algumas exceções, por exemplo, no $\operatorname{RAR} \gamma$ a hélice $\mathrm{H} 2$ não está presente, enquanto que no PPAR $\gamma$, uma hélice adicional, H2', é observada (2). No nível terciário, esse conjunto de hélices $\alpha$ está arranjado de modo a formar um "sanduíche" de hélices paralelas. As hélices H1, H3, H7, H10 e H11 formam os planos mais externos, já as hélices H4, H5, H6, H8, H9 compõem o plano intermediário do sanduíche. A hélice 12, responsável pela função de ativação dependente do ligante (AF-2) localiza-se perpendicularmente às outras hélices entre os planos externos, podendo adotar diferentes conformações dependendo da natureza do ligante que está associado ao LDB. A cavidade de ligação com ligante, LBP (Ligand Binding Pocket) está localizada no interior do LBD, geralmente atrás da hélice 3 e em frente às hélices 7 e 10 (3), 8). A figura 1.4 mostra a estrutura do LDB do RAR, destacando cada hélice e os 3 planos do sanduíche (13).

Além da função de ativação dependente do ligante, o LBD é responsável pela formação de dímeros, essencial para a atividade dos receptores. As superfícies de dimerização compreendem aproximadamente $11 \%$ da área superficial dos LBDs e corresponde a regiões próximas às hélices 10 e 11.

\subsubsection{Interação com proteínas correguladoras}

Receptores nucleares são fatores de transcrição que regulam a transcrição de determinados genes em resposta à ligação de hormônios ou metabólitos. A primeira etapa da regulação é iniciada com a ligação do ligante no LBP e, por isso, o mecanismo pelo qual os ligantes 


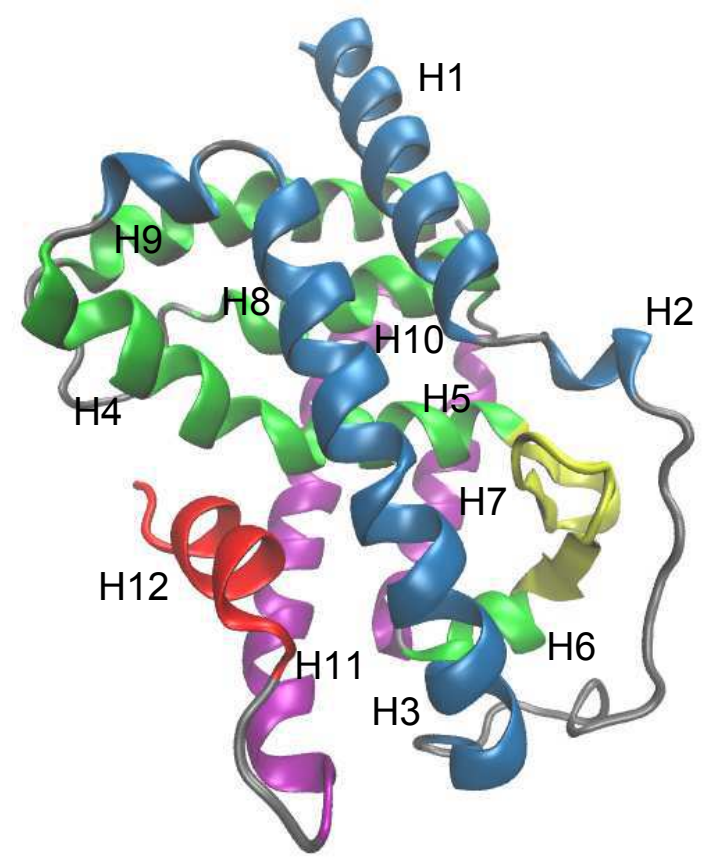

Figura 1.4 - Estrutura do $L D B$ do receptor do ácido retinóico. O $L B D$ forma um "sanduíche". Em azul, verde e roxo estão mostradas as hélices dos três planos. A hélice 12 está em vermelho (PDB: 2LBD) (13).

modulam a atividade dos receptores nucleares tem despertado grande interesse nos últimos anos. A segunda etapa da regulação da atividade dos receptores é a interação com proteínas correguladoras, as quais interagem diretamente com estes e possuem papel fundamental na mediação do efeito do ligante no processo da transcrição de genes $(3,9)$. Proteínas correguladoras podem ser coativadoras ou correpressoras, dependendo do efeito que provocam, podendo ativar ou inibir a transcrição. Correpressores se ligam aos receptores nucleares na ausência de ligante ou na presença de antagonistas, impedindo a transcrição. Na presença de um agonista, a proteína correpressora é liberada e um coativador é recrutado, possibilitando, assim, a transcrição do gene-alvo (10).

Após a identificação de proteínas correguladoras, o objetivo de diversos estudos foi a definição de como é dada a interação dessas proteínas com os receptores nucleares. Foi observado que proteínas coativadoras e correpressoras contêm múltiplas sequências conservadas de interação com os receptores. Essas curtas sequências podem ser generalizadas como LxxLL em coativadores e $L x x x \mid x x x[I / L] \dagger$ em correpressores. Estudos mutacionais foram realizados para mapear a superfície do LBD que interage com as proteínas correguladoras e mostraram que coativadores e correpressores compartilham a mesma superfície de interação, tornando a associação de coativadores e correpressores eventos mutuamente exclusivos. Dessa forma, o

†L e I são Leucina e Isoleucina, respectivamente. Os "x" são resíduos variáveis 
receptor deve selecionar qual tipo de corregulador será recrutado ao LBD, e isso é controlado pelo ligante (3).

Estudos estruturais de LBDs ligados a agonistas e a peptídeos com sequência LxxLL revelaram que o modo de ligação de proteínas coativadoras com LBD é conservado. A região do coativador que se liga ao receptor nuclear adota uma conformação helicoidal, que interage com uma região hidrofóbica na superfície do LBD. Essa superfície de interação é formada por duas partes: uma constante, composta pelas hélices 3 e 4 e outra variável formada pela hélice 12. A parte constante, adota a mesma conformação em diferentes estruturas de LBDs e não é afetado pela presença do ligante. Entretanto, a segunda parte, constituída pela H12 pode adotar diferentes conformações, dependendo do ligante. Uma importante interação entre o coativador e a superfície do LBD ocorre entre uma porção carregada formada por uma lisina e um ácido glutâmico das hélices 3 e 12, respectivamente, e o dipolo da hélice do coativador (10).

Observando as estruturas do complexo LBD-coativador, fica evidente que o posicionamento adequado da hélice 12 é essencial para suportar a presença do coativador (3, 10). A figura 1.5(a) mostra a estrutura do LBD de PPAR $\alpha$ ligado a um agonista e a uma proteína coativadora (11, 12). Embora a superfície de interação de coativadores e correpressores seja a mesma, são observadas diferenças estruturais no modo de ligação destes, principalmente no que diz respeito a posição da hélice 12. O motivo através do qual correpressores se ligam ao receptor é bastante similar ao dos coativadores, exceto pela sua extensão N-terminal. Enquanto o motivo LxxLL forma uma hélice $\alpha$ de duas voltas, o motivo Lxxxlxxx[I/L] dá origem a uma hélice $\alpha$ de 3 voltas. A volta extra da hélice dos correpressores ocupa a posição da hélice 12 na conformação ativa. Como consequência dessa volta adicional, a hélice C-terminal se desloca para uma posição alternativa para dar lugar ao correpressor, dando ao receptor uma conformação inativa, que geralmente é estabilizada pela presença de antagonistas, como mostrado na figura 1.5(b). Dessa forma, parece evidente que a interação com coativadores e correpressores é fortemente dependente da posição da hélice 12.

\subsection{Dinâmica da Hélice 12}

Em 1995 foram determinadas as primeiras estruturas cristalográficas dos LBDs dos receptores RAR e RXR, sendo a primeira associada ao ácido retinóico e a segunda sem ligante $(13,14)$. A determinação dessas estruturas despertou grande interesse na compreensão do 

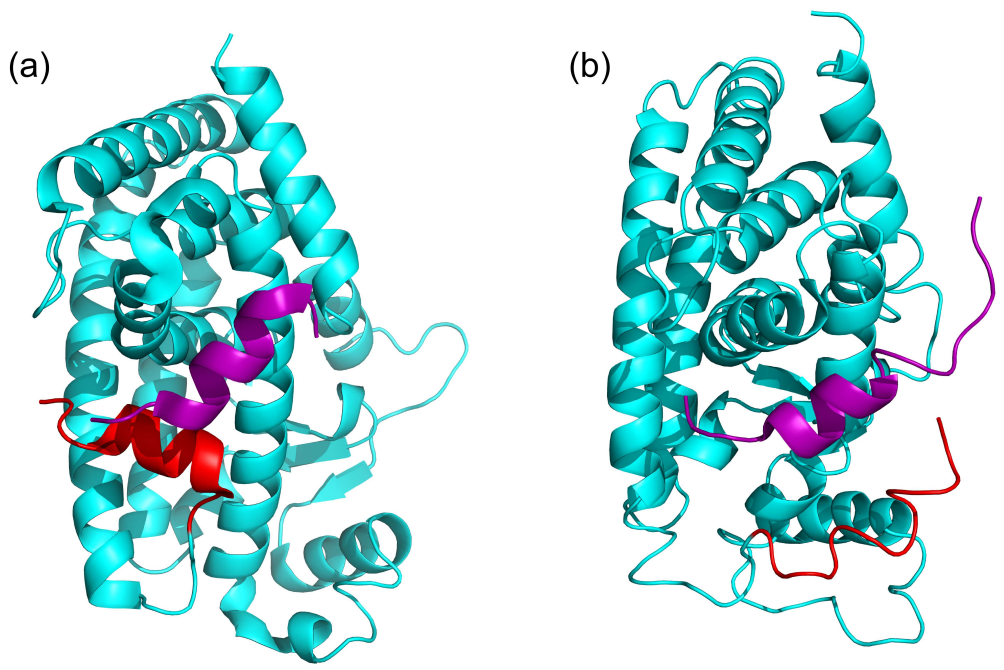

Figura 1.5 - Estrutura cristalográfica do PPAR ligado ao (a) coativador (PDB: $1 K 7 L$ ) e ao (b) correpressor (PDB: 1KKQ). A hélice 12 está representada em amarelo e os peptídeos correguladores em roxo. Destaque para a posição da H12 nas duas estruturas e para a extensão $N$-terminal do corregulador (11, 12).

papel funcional da dinâmica do LBD, em especial, na mobilidade da hélice 12. A principal diferença observada entre a estrutura holo e a estrutura apo foi a posição da hélice C-terminal. Na figura 1.6 nota-se que na ausência de ligante a H12 e o loop entre a H11 e a H12 projetamse para fora do corpo do LBD, deixando exposto o sítio de ligação com o ligante. Entretanto, na presença do ácido retinóico, a H12 posiciona-se sobre o corpo do LBD, fazendo com que o ligante fique completamente enterrado no sítio de ligação. Da comparação entre as duas estruturas foi proposto um mecanismo para a entrada e a saída do ligante, que ficou conhecido como mecanismo da "ratoeira". Segundo esse mecanismo, a hélice 12 permaneceria "aberta" na ausência de ligante e, a entrada do ligante induziria o fechamento da hélice 12 (figura [1.6) (13-14). Apesar desse mecanismo ter sido fortemente acreditado na literatura, apresenta algumas inconsistências, e tem sido abandonado, pelo menos da forma como foi proposto inicialmente. Estudos cristalográficos de LBDs de vários receptores nucleares sugerem a que a mobilidade da $\mathrm{H} 12$ parece ser menos dramática do que foi sugerido a partir da comparação entre as estruturas do RAR e do RXR. Além disso, estruturas de ER e PPAR na ausência de ligante e de receptores órfãos mostram uma posição para a hélice 12 mais similar à observada em estruturas holo que à estrutura apo do RXR (15-16). Por fim, experimentos de troca hidrogênio/deutério mostraram que em receptores de hormônio da tireoide, a H12 protege o LBD tanto na ausência, quanto na presença do ligante, evidenciando que essa hélice não se encontra estendida em relação ao corpo da proteína em ambos os casos (19)

O papel funcional da dinâmica da hélice 12 parece estar mais relacionado com a asso- 

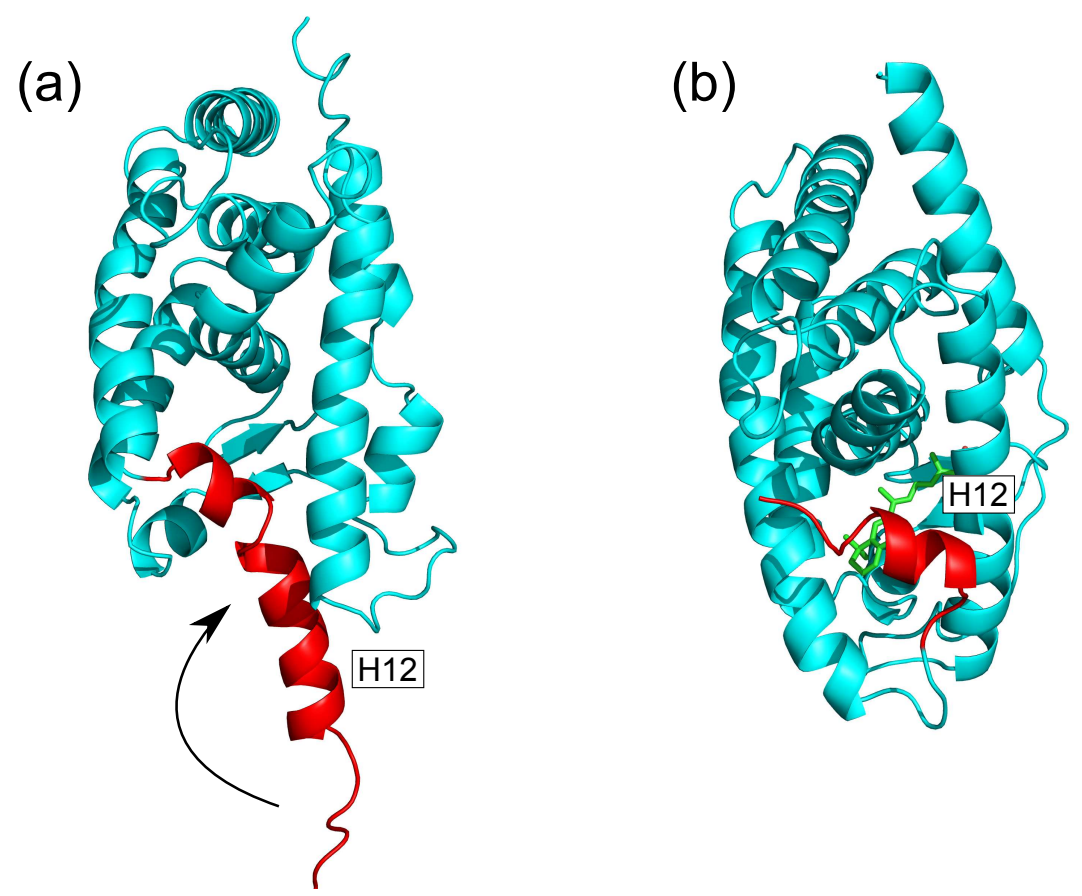

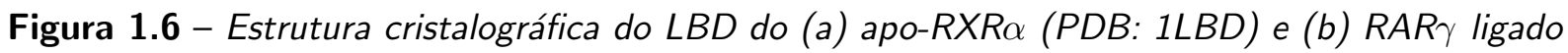
ao ácido retinóico (PDB: $2 L B D)$. Destaque para a mudança conformacional da hélice 12 observada entre as duas estruturas $(13,14)$.

ciação de coativadores e correpressores do que com a entrada e saída dos ligantes do LBD. Como discutido na sessão anterior, a ativação da transcrição é dependente da substituição de correpressores por coativadores, o que é controlada pelo posicionamento da H12. Dessa forma, a visão atual é que o LBD e em especial a H12, se encontra em um equilíbrio conformacional dinâmico, entre a conformação ativa e inativa. A ligação com agonistas deslocaria o equilíbrio no sentido de estabilizar a $\mathrm{H} 12$ na posição ativa, formando a superfície de interação com coativadores e, consequentemente, favorecendo a transcrição. Na ausência de ligante, o equilíbrio seria deslocado do sentido de favorecer a interação com correpressores.

Diversos estudos mostram que a presença de um ligante promove rearranjos na estrutura do LBD, no sentido de torná-lo mais estável. Entretanto, os mecanismos moleculares associados à esse processo ainda não são completamente compreendidos, principalmente devido à dificuldade da determinação de estruturas cristalográficas dos LBDs na sua forma apo $(10,20)$. Embora apenas estudos estruturais não sejam suficientes para elucidar o papel do ligante na dinâmica do LBD, estudos bioquímicos e biofísicos complementares tem auxiliado na compreensão das diferenças entre as estruturas apo e holo de LBDs dos receptores nucleares. Os resultados desses estudos mostram que receptores nucleares na ausência de ligante, são em geral, mais sensíveis a proteólise que os receptores na sua forma holo. Análises de gel filtração mostram uma redução do tamanho do LBD na presença do ligante. Adicionalmente, 

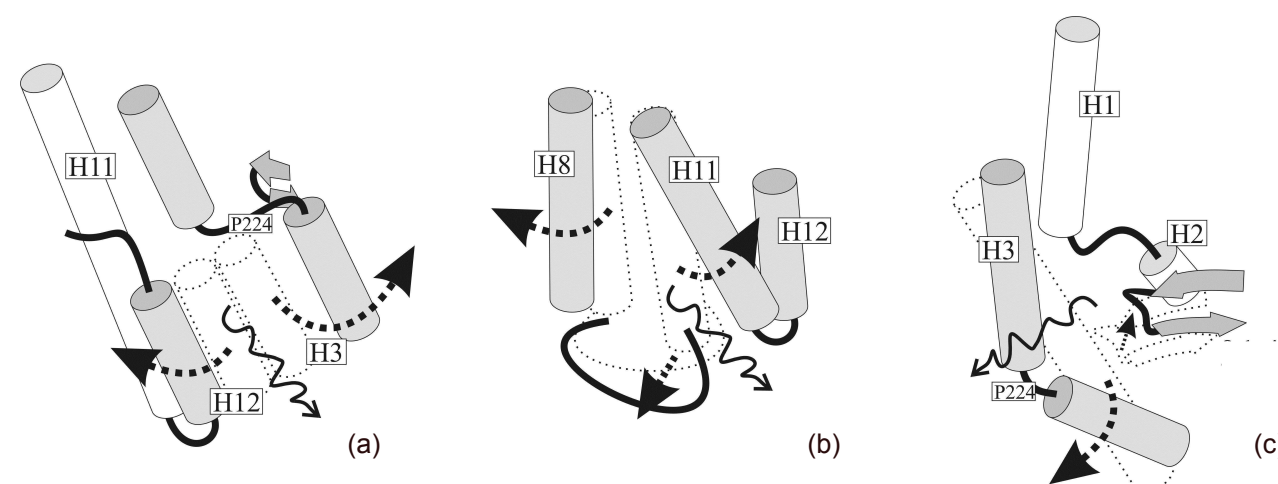

Figura 1.7 - Caminhos de dissociação do ligante em TR: (a) Caminho I: saída do ligante se dá através de uma abertura originada pelo deslocamento da H12. Esse caminho assemelha-se ao mecanismo da "ratoeira"(b) Caminho II: o ligante se dissocia através da separação formada entre a H8 e a H11. (c) Caminho III: a H3 é quebrada em duas partes e a movimentação da folha $\beta$ abre uma cavidade por onde o ligante escapa. Os dois últimos mecanismos não contradizem a associação com cofatores. Reproduzido de (21).

estudos de desnaturação térmica revelam que LBDs com ligantes apresentam um aumento na temperatura de desnaturação se comparados com apo-LBDs. Em conjunto, esses resultados sugerem que holo-LBDs são mais compactos, rígidos e estáveis que seu corresponde na forma apo, indicando que o ligante exerce um forte efeito estabilizador no LBD (10).

\subsubsection{Mecanismos de dissociação de ligantes}

O mecanismo da "ratoeira", baseado nas estruturas dos LBD de RAR e RXR com e sem ácido retinóico, propõe um modelo para a associação e dissociação do ligante com o LBD de receptores nucleares, através do deslocamento da hélice 12. Entretanto, esse modelo apresenta algumas incoerências e, por isso, tem sido questionado. A principal inconsistência vem do fato dos coativadores se ligarem sobrepondo-se à hélice 12. Como discutido na sessão 1.2.4, a ligação com um agonista promove um rearranjo na posição da H12, criando uma superfície de interação com proteínas coativadoras adequada. Porém, da forma como o modelo da "ratoeira" foi proposto, seria necessário, primeiramente que o coativador se dissociasse da superfície do LBD para permitir a liberação do ligante. Entretanto, isso é pouco provável, uma vez que o coativador é muito maior que a molécula de ligante e, dessa forma, sua saída deve ocorrer em uma escala de tempo maior. Além disso, espera-se que a associação e dissociação do ligante, e não do coativador, seja o fator regulador da atividade.

Diversos trabalhos, principalmente utilizando simulações computacionais, buscaram com- 
preender o mecanismo de dissociação de ligantes, tentando encontrar caminhos alternativos para a saída do ligante, de forma que este possa sair e induzir alterações conformacionais promovendo a liberação dos coativadores. Dois trabalhos utilizando técnicas diferentes de dinâmica molecular foram realizados para estudar os mecanismo de dissociação do ácido retinóico do LBD de RAR. Em ambos foi observada a dissociação do ligante através de um canal formado pela abertura da hélice 12 , entretanto, não foi verificada a abertura total da H12 como na estrutura de apo-RXR (1.6(a)). Em um desses trabalhos foi observado também um caminho alternativo, que não envolve a $\mathrm{H} 12$, no qual o ligante se dissociaria através de uma abertura na superfície da proteína, entre as hélices H1 e H3 (20-21).

Posterior a esses trabalhos, nosso grupo estudou a associação e dissociação de ligantes de receptores de hormônio da tireoide, onde foram observados caminhos alternativos para a dissociação. As simulações para TR, revelaram três possíveis caminhos de saída do ligante (figura 1.7). O caminho I envolvendo uma abertura entre a $\mathrm{H} 3$ e a $\mathrm{H} 11$ provocada pelo deslocamento da H12, similar ao observado nos trabalhos discutidos acima. O segundo caminho, nunca observado antes, sugeriu como rota de saída, a região entre a $\mathrm{H} 8$ e a $\mathrm{H} 11$, com a abertura do $\Omega$-loop. Por fim, o caminho III envolve uma cavidade formada pela movimentação da folha $\beta$, do loop entre a $\mathrm{H} 1$ e a $\mathrm{H} 2$ e da $\mathrm{H} 3$, sendo este o mais favorável. Além disso, foi demostrado que para a entrada do ligante até o LBP são requeridas apenas pequenas perturbações conformacionais na estrutura do LBD $(18-19,22)$. Em conjunto, esses resultados sugerem que grandes alterações estruturais como o proposto no modelo da "ratoeira" não são necessárias para a entrada e saída do ligante. 


\section{CAPÍTULO 2}

\section{Receptores ativados por proliferadores}

\section{de peroxissomos - O PPAR $\gamma$}

Os receptores ativados por proliferadores de peroxissomos (PPAR, peroxisome proliferator activated receptor) pertencem à classe II da superfamília dos receptores nucleares (1). 0 nome do receptor teve origem na observação de que, em roedores, esta proteína era ativada por proliferadores peroxissomais, tais como fibratos e ácidos graxos (25). Em humanos, são encontradas três isoformas de PPAR: $\alpha, \beta / \delta$ e $\gamma$. Essas isoformas são produtos de diferentes genes e diferem entre si em relação a sua distribuição nos tecidos, especificidade aos ligantes e funções biológicas (26).

O PPAR $\alpha$ é encontrado principalmente no fígado, rim e coração e é importante para a absorção e oxidação de ácidos graxos e para o metabolismo de lipoproteínas. A isoforma $\beta / \delta$ do PPAR é expresso em diversos tecidos, especialmente nos rins, pulmões, músculos esquelético e cardíaco. Agonistas desse receptor desempenham importante papel no tratamento de dislipidemia e de câncer, além de influenciar na diferenciação de células do sistema nervoso central. Por fim, o PPAR $\gamma$ é expresso predominantemente no tecido adiposo e em menores níveis é encontrado também na mucosa do duodeno e na retina. Desempenha papel fundamental na diferenciação de adipócitos e interage com uma classe bem conhecida de sensibilizadores de insulina, os fármacos anti-diabéticos da família das tiazolidinedionas (TZD) (26). Devido à sua importância como alvos farmacêuticos no tratamento de desordens envolvendo o metabolismo de lipídeos e no tratamento de diabetes, os LBDs de PPARs têm sido objeto de diversos estudos. Esse trabalho tem como foco a isoforma $\gamma$ do PPAR. Detalhes de seus aspectos funcionais, estruturais e dinâmicos serão discutidos nesse capitulo. 


\subsection{Funções biológicas do PPAR $\gamma$}

Desde a sua descoberta nos anos 90, até hoje, tem ficado claro o papel do receptor PPAR $\gamma$ na regulação de vias complexas do metabolismo de mamíferos, especialmente na regulação do metabolismo de lipídeos e carboidratos com implicações importantes na homeostase energética. Mais recentemente, o PPAR $\gamma$ foi também associado à processos inflamatórios, à arterosclerose e ao câncer. O PPAR $\gamma$ está intimamente envolvido no metabolismo de lipídeos, tendo importância central na diferenciação e manutenção das funções dos adipócitos. Vários estudos mostram o papel fundamental desse receptor na regulação da adipogênese. PPAR $\gamma$ é induzido durante a diferenciação de pré-adipócitos em adipócitos. Estudos posteriores suportaram essa idéia mostrando que na presença de PPAR $\gamma$ com mutações associadas à perda de função, não foi observada adipogênese em culturas de pré-adipócitos. Além da adipogênese, o PPAR $\gamma$ está envolvido na manutenção das funções dos adipócitos, como armazenamento de lipídeos e liberação de energia (25, 27).

A descoberta dos TZDs, moléculas com conhecida ação hiploglicêmica, usadas no tratamento de diabetes do tipo II, como ligantes de alta afinidade do PPAR $\gamma$, despertou interesse na compreensão do papel desse receptor na resistência à insulina. Estudos mutacionais em $\operatorname{PPAR} \gamma$ de roedores mostraram essa relação. Roedores nos quais o PPAR $\gamma$ exibia alto nível de atividade apresentaram sensibilidade à insulina. Por outro lado, roedores que não expressavam essa isoforma desenvolveram alta resistência à insulina, desenvolvendo diabetes do tipo II. O mecanismo pelo qual o PPAR $\gamma$ regula a sensibilidade à insulina está relacionado ao seu papel na adipogênese. A diabetes tipo II está associada com o aumento dos níveis de ácidos graxos livres (FFA, Free fatty acids) no plasma e à deposição e acúmulo de lipídeos em tecidos inapropriados, como o fígado e o músculo esquelético. O acúmulo de FFA e lipídeos nesses tecidos está intimamente associado com a resistência à insulina e compromete a disponibilidade de glicose. Quando ativo, o PPAR $\gamma$ induz a adipogênese, capturando os FFA e lipídeos presentes nos tecidos inapropriados e armazenando-os em adipócitos especializados.

\subsection{Estrutura do PPAR $\gamma$}

O PPAR $\gamma$, por pertencer a superfamília dos receptores nucleares, apresenta características estruturais similares ao demais membros dessa família. Nesse receptor, é possível observar os 


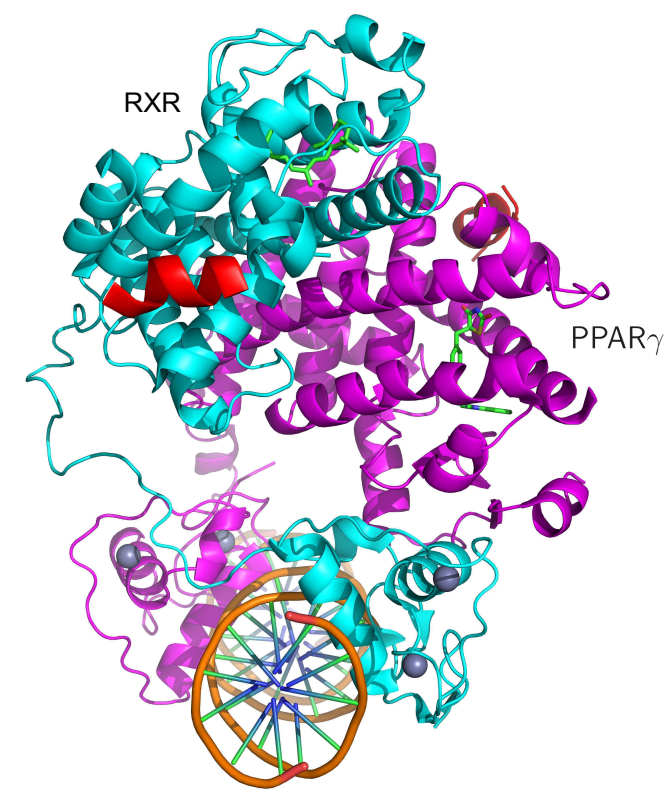

Figura 2.1 - Estrutura do heterodímero de PPPAR e RXR $\alpha$ sobre o DNA (PDB: $3 D Z Y)$. Em lilás está representada a estrutura do PPAR $\gamma$, em azul do $R X R \alpha$, em vermelho dos peptídeos coativadores e em cinza os íons de Zinco. Na parte superior, são observados os $L B D$ s e na inferior os $D B D s$ (28).

três domínios presentes nos demais receptores: o domínio N-terminal, o domínio central de ligação com o DNA, bastante conservado, e o domínio de ligação com o ligante, que apresenta algumas diferenças estruturais em relação aos demais receptores. A isoforma $\gamma$ do PPAR, como todos os membros da classe II dos receptores nucleares, atua na forma de heterodímeros com o RXR. Em 2008, foi determinado, através de difração de raios-X, a primeira estrutura de PPAR $\gamma$ contendo o DBD, o LBD e um peptídeo coativador em um complexo com o RXR. A figura 2.1 mostra a estrutura do heterodímero ligado ao DNA. Nessa estrutura é possível observar que além da interação com o DNA promovida pelos dedos de zinco, a extensão C-terminal (CTE) do DBD do PPAR $\gamma$ possui uma interação significativa com o DNA. A CTE é seguida por dois pequenos segmentos helicoidais que atingem o LBD, essa região é denominada hinge. Entretanto, essa interação do CTE com o DNA não é observada no RXR $\alpha$. Nesse receptor, essa região constitui um dos contatos diméricos com PPAR $\gamma$ (28). Essa estrutura revela que existem três regiões de dimerização entre os dois receptores, sendo a mais importante, a superfície de interação entre os LBDs. A interface formada entre os LBDs é constituída por uma rede de interações hidrofóbicas e polares, envolvendo as hélices $\mathrm{H} 7, \mathrm{H} 9, \mathrm{H} 10$ e o loop entre as hélices $\mathrm{H} 8$ e $\mathrm{H} 9$ de ambos os receptores, sendo que as principais interações envolvidas na dimerização ocorrem entre as hélices $\mathrm{H} 10$ do $\operatorname{PPAR} \gamma$ e do $\operatorname{RXR} \alpha$ (26-27). 


\subsubsection{O LBD do PPAR $\gamma$}

A estrutura do LBD do receptor PPAR $\gamma$ foi determinada em 1998, por cristalografia, e revelou uma estrutura tridimensional comum a todos os receptores nucleares: um sanduíche de hélices $\alpha$, formando três camadas paralelas entre si, e pequenas fitas- $\beta$. Porém, no nível secundário, esse receptor apresenta uma particularidade. Diferentemente das outras proteínas dessa família, que em geral possuem 12 hélices $\alpha$, o PPAR $\gamma$ possui uma hélice adicional, localizada entre a primeira fita da folha- $\beta$ e a H3, chamada de hélice H2' (18).

Uma segunda particularidade do LBD do PPAR $\gamma$, agora no nível terciário, é o volume do seu sítio de ligação. O sítio de ligação desse receptor é uma cavidade localizada na parte inferior do LBD, com um volume que varia entre $1300 \AA^{3}$ e $1400 \AA^{3}$, o que é consideravelmente maior que os LBPs dos demais receptores (26). Essa variação no volume do LBP entre os receptores está relacionada com a função biológica desempenhada por eles. A cavidade volumosa do $\operatorname{PPAR} \gamma$ permite que este se ligue a diversos metabólitos, com afinidades diferentes sendo, por isso, considerado um receptor promíscuo. Entretanto, receptores como o RXR e o TR, que possuem cavidades bem menos volumosas, ligam-se com alta afinidade ao ácido retinóico e ao hormônio tireoidiano, respectivamente (3).

O LBP do PPAR $\gamma$ é delimitado pelas hélices H2', H3, H4, H5, H7, H10, H11, H12 e pela folha- $\beta$. Essa cavidade é geralmente descrita como um bolsão em forma de " $Y$ ", com cada um dos três braços medindo entre 16 e $20 \AA$. Um dos braços apresenta propriedades físicoquímicas bastante distintas dos demais. Com cinco resíduos polares, o braço I forma uma região com grande potencial de formação de ligações de hidrogênio, já os braços II e III são essencialmente hidrofóbicos. Uma das prolongações do LBP situa-se entre a $\mathrm{H} 3$ e a folha- $\beta$, a segunda entre a $\mathrm{H} 3$ e a $\mathrm{H} 5$ e a terceira localiza-se entre a $\mathrm{H} 12$ e a $\mathrm{H} 3(18,26)$.

\subsection{O PPAR $\gamma$ e a hélice 12}

Como discutido no capitulo anterior, a posição da hélice 12 em relação ao corpo do LBD é importante para o recrutamento de proteínas correguladoras e, consequentemente, para a ativação e desativação do receptor. Estruturas cristalográficas de PPAR na presença de agonistas totais, revelam que a $\mathrm{H} 12$ adota uma conformação ativa, posicionando-se perpendicularmente às hélices externas do LBD e criando uma superfície de interação com proteínas 


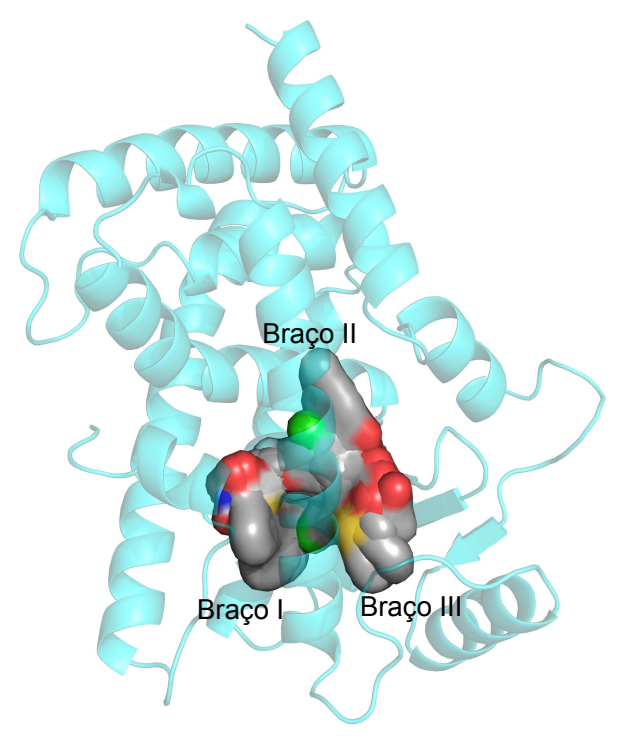

Figura 2.2 - Estrutura do $L B D$ do receptor PPARy (PDB: 2PRG). Destaque para a cavidade de ligação com o ligante na forma de $Y(18)$.

coativadoras (18). Por outro lado, na presença de antagonistas, a H12 adota uma conformação inativa, favorecendo a interação com correpressores. Essas informações revelam que o ligante exerce efeito no posicionamento da hélice 12 e, dessa forma, na seleção dos correguladores e na atividade transcricional.

\subsubsection{Mecanismos de ativação}

Tradicionalmente, os mecanismos propostos para a ativação induzida pelo ligante envolvem mudanças conformacionais ou estabilização da H12, que compõe o domínio de ativação AF-2. Entretanto, o PPAR $\gamma$ pode ser ativado, em menor proporção, por agonistas parciais que não interagem com a hélice 12. Agonistas totais, como a rosiglitazona, pertencente a classe dos TZDs, interagem diretamente com a hélice 12 do LBD através de ligações de hidrogênio com a Tyr473, estabilizando a hélice em uma posição ativa e, consequentemente, favorecendo o sítio de ligação com o coativador. Estudos de troca hidrogênio/deutério para PPAR $\gamma$ confirmam a estabilização da região da $\mathrm{H} 12$ na presença de agonistas totais (30).

Estruturas cristalográficas de PPAR $\gamma$ ligado a agonistas parciais mostram um sítio de interação diferente daquele observado para agonistas totais, podendo estar localizados entre as hélices $\mathrm{H} 11$ e $\mathrm{H} 3$ ou entre a $\mathrm{H} 3$ e a folha- $\beta$. Dessa forma, agonistas parciais não promovem a estabilização da hélice 12 a partir da interação com a Tyr473. Por outro lado, promovem 
uma forte estabilização da $\mathrm{H} 3$ e da folha- $\beta$, observada através de experimentos de troca hidrogênio/deutério. Na presença de agonistas totais, essas regiões são estabilizadas em menor proporção (30-32).

Estruturas de apo-PPAR $\gamma$ são escassas, além disso, não é garantido que se tratem realmente de estruturas apo, uma vez que o sítio de ligação com o ligante do PPAR $\gamma$ é bastante volumoso, podendo conter ligantes móveis, como ácidos graxos, difíceis de serem modelados. Nessas estruturas sugeridas como apo-PPAR $\gamma$ a H12 apresenta uma conformação próxima da sua conformação ativa, podendo inclusive recrutar proteínas coativadoras (14, 18, 35), corroborando a idéia de que a $\mathrm{H} 12$ não precisa sofrer alterações conformacionais tão dramáticas para promover a ativação do receptor nuclear.

\subsubsection{Aspectos dinâmicos do LDB de PPAR $\gamma$}

Estudos cristalográficos revelaram pequenas diferenças entre as estruturas de LBDs de $\operatorname{PPAR} \gamma$ na sua forma apo e ligado a agonistas. Essa grande similaridade entre as estruturas apo, ligado a agonistas totais e ligado a agonistas parciais levantam a hipótese de que o modo de ligação do ligante, além de controlar a atividade do receptor, interfere também, nas propriedades dinâmicas do LBD, em especial da H12 e da superfície AF-2. Dando suporte a ideia de que para a máxima ativação é necessário contato direto com a $\mathrm{H} 12$ e, consequentemente, sua estabilização. Estruturas de agonistas parciais ligados ao PPAR $\gamma$ não mostram interações entre os ligantes e a hélice 12 (2.3(d)). Dessa forma, o grau de estabilização da hélice 12 é proporcional ao grau de agonismo do ligante e a resposta transcricional (30).

O estudo das propriedades dinâmicas do LBD de PPAR $\gamma$ tem sido complementado através da utilização de diversas técnicas bioquímicas e biofísicas. Assim como para os receptores nucleares em geral, estudos mostram que na presença de um ligante, o LDB é mais rígido, mais compacto e mais estável que sua forma apo. Especificamente para o PPAR $\gamma$, a distribuição dos fatores de temperatura do seu LBD sugere que a parte inferior, que contém a cavidade de ligação, possui maior mobilidade conformacional que a parte superior, especialmente para a forma apo (10). Esse mesmo resultado é observado em estudos de ressonância magnética nuclear (36).

Concordando com a ideia de que a interação com um ligante afeta a dinâmica do LBD, estudos de anisotropia de fluorescência (que serão discutidos com mais detalhes posteriormente) mostraram que a hélice 12 exibe uma maior mobilidade na ausência de ligantes, com movi- 
(a)

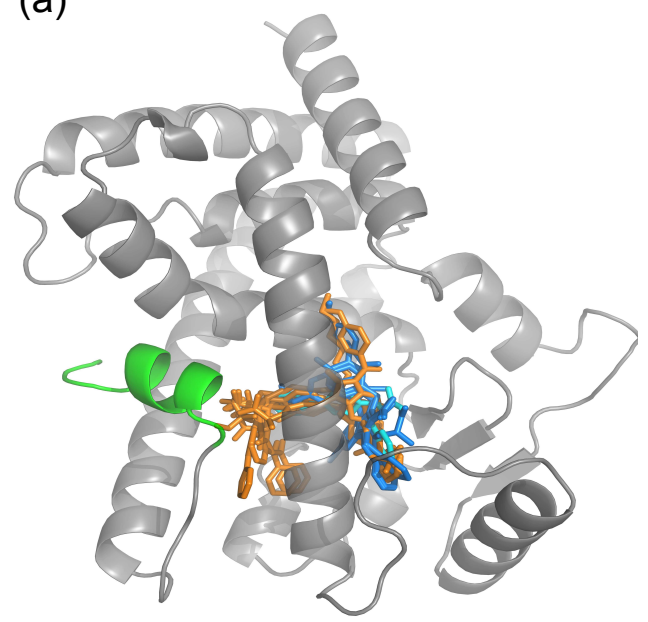

(c) PPARy + Rosigliotazona

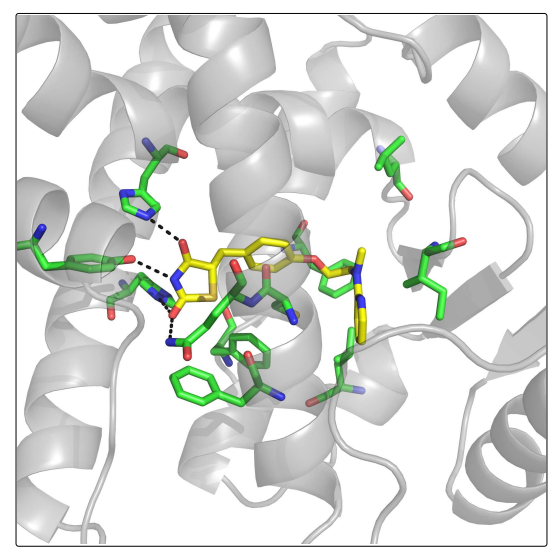

(b)

Agonistas totais

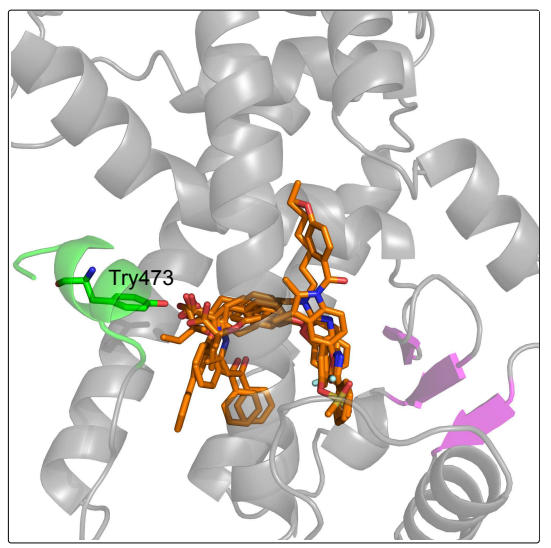

(d) Agonistas parciais

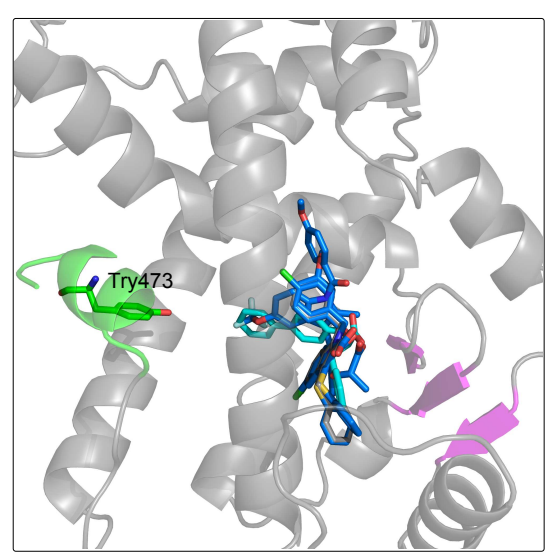

Figura 2.3 - (a) Superposição de agonistas de PPAR no seu LBD: em laranja estão representados os agonistas totais e em azul os agonistas parciais. (Agonistas totais: PBD 2PRG (18), 1FM9 (29), 2ATH, 2I4J (3C), $2 Q 59$ (30) e 3B3K (33). Agonistas parciais: 4PRG (34), 2Q5P (30), 2Q5S, 2Q6R (30), 2Q61 (30) e 3D6D (33))(b) Ampliação do sitio de ligação na presença de agonistas totais: é possível perceber a proximidade de todos ligantes com a Try473, formando interações de hidrogênio que estabilizam a H12 na sua conformação ativa. (c) Interação entre os resíduos da cavidade de ligação com o ligante e a rosiglitazona, um agonista total. (d) Ampliação do sitio de ligação com o ligante na presença de agonistas parciais: esses ligantes ocupam uma região alternativa, não interagindo diretamente com a hélice 12. Adaptado de (31). 
mentos na escala da nanossegundos. Entretanto, quando ligado a rosiglitazona, um agonista total, apresenta uma dinâmica mais lenta. Também foi observada uma maior mobilidade em estruturas mutadas, nas quais a hélice 12 estava impedida de adotar sua conformação ativa (37). O mesmo é observado em experimentos de troca hidrogênio/deutério (30, 38). Esses resultados evidenciam o efeito do ligante na dinâmica do LBD, em especial da hélice 12. Além disso, mostram que a atividade do PPAR $\gamma$ parece estar relacionada não só com a conformação adotada por essa hélice, mas, principalmente com as características dinâmicas que ela exibe, uma vez que níveis transcricionais mais elevados são atingidos na presença de agonistas totais, capazes de estabilizar a hélice 12 e diminuir sua mobilidade. 


\section{CAPÍTULO 3}

\section{Simulações de Dinâmica Molecular}

Para completa compreensão do modo de ação de uma macromolécula biológica é necessário conhecer não só sua estrutura tridimensional, que pode ser obtida experimentalmente através de difração de raio-X ou por RMN, mas também sua dinâmica. Algumas técnicas experimentais são capazes traduzir certas propriedades dinâmicas, porém simulações de dinâmica molecular (MD, Molecular Dynamics) destacam-se como uma importante ferramenta teórica capaz de fornecer informações sobre o comportamento dinâmico em escala molecular (39).

Resumidamente, simulações de dinâmica molecular baseiam-se na construção de um modelo capaz de reproduzir cada molécula e todas as interações intermoleculares. A partir desse modelo e de condições iniciais é possível resolver a equação de movimento de cada átomo, obtendo a evolução temporal do sistema. Uma vez que essa técnica consiste em um modelo teórico, a comparação com dados experimentais é fundamental para a validação dos resultados.

A primeira simulação de dinâmica molecular de proteínas foi publicada em 1977, onde foi realizado o estudo de uma pequena proteína em vácuo. Nesse primeiro trabalho foi gerada uma trajetória de apenas 9,2 ps (40). Como resultado desse trabalho, a antiga visão de proteínas como uma estrutura rígida foi substituída por uma visão onde proteínas são sistemas dinâmicos cujo movimento interno é essencial para sua função. Onze anos depois, devido o aumento da capacidade computacional, foi possível estudar essa mesma proteína em água, com trajetórias de mais de 200 ps. Atualmente, com o contínuo desenvolvimento de novas metodologias e com o aumento da capacidade de processamento, estudos através de dinâmica molecular podem ser aplicados para sistemas maiores e em grandes escalas de tempo. Isso torna possível a investigação de movimentos que possuem importância funcional e que não são acessíveis por técnicas experimentais (41)

Neste capítulo, serão apresentados alguns conceitos fundamentais de dinâmica molecular, principal técnica utilizada em nosso trabalho. 


\subsection{Potenciais de interação}

Nesse trabalho foram realizadas apenas simulações de dinâmica molecular clássicas, isso significa que nenhum efeito quântico foi explicitamente considerado. Entretanto, embora todos os átomos tenham sido tratados como partículas clássicas, os potenciais utilizados em simulações de dinâmica molecular clássica são aproximações de potenciais quânticos. Em princípio, a evolução temporal da posição de uma partícula pode ser obtida pela resolução da equação de Schroedinger dependente do tempo que fornece a probabilidade de encontrar a partícula em uma posição $x$ no instante de tempo $t$.

$$
\frac{-\hbar^{2}}{2 m} \nabla^{2} \Psi(\mathbf{x}, t)+V(\mathbf{x}, t) \Psi(\mathbf{x}, t)=i \hbar \frac{\partial \Psi(\mathbf{x}, t)}{\partial t}
$$

Entretanto a resolução dessa equação para sistemas com milhares de átomos é inviável. Dessa forma, para sistemas grandes, como sistemas biológicos, utiliza-se uma descrição das interações através de potenciais clássicos, os quais não são independentes das propriedades quânticas. Potenciais com diferentes formas podem ser usados para representar as interações entre as partículas do sistema (42). Esses potenciais foram desenvolvidos tentando reproduzir a dependência com a distância das energias quânticas. Para o estudo de muitas propriedades dinâmicas de macromoléculas biológicas, a temperatura ambiente, o uso de potencias clássicos são suficientemente precisos.

Diversos potenciais clássicos, também chamados de campos de força, foram desenvolvidos e aplicado com sucesso na área de simulações de proteínas. Dentre eles, destacam-se os campos de força CHARMM (40-41), OPLS (44), AMBER (45) e GROMOS (46). Estes campos de força descrevem as interações entre diferentes átomos pela soma de interações de curto alcance do tipo Lennard-Jones, termos de interação eletrostática coulombianos e potenciais internos de estiramento e distorção de ligações e torções de diedros. Assim, o campo de força tem a forma

$$
V^{\text {Total }}=V^{\text {Intra }}+V^{\text {Inter }}
$$

Nesse trabalho foi utilizado o campo de força CHARMM. Este campo de força pode utilizar até cinco termos para modelar as interações entre átomos ligados covalentemente. Os três principais termos representam o estiramento das ligações químicas, a deformação angular e as torções diedrais. A figura 3.1 ilustra esses termos. 
(a)

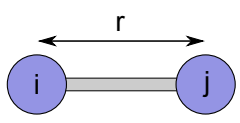

(b)

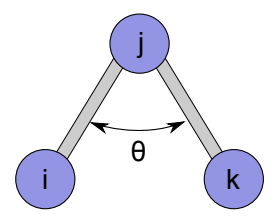

(c)

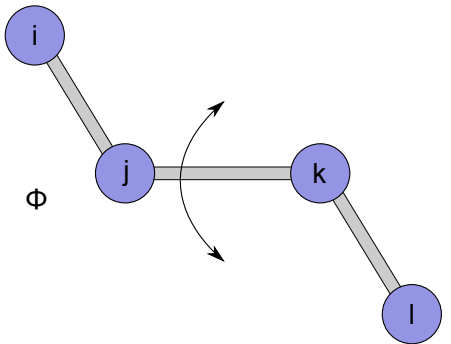

Figura 3.1 - Esquema mostrando os termos utilizados para modelar as interações entre átomos ligados covalentemente: (a) estiramento das ligações químicas, (b) deformação angular entre átomos ligados sucessivamente e (c) torções diedrais associadas a quatro átomos ligados sucessivamente.

O termo que representa o estiramento das ligações é descrito por um potencial harmônico e tem a seguinte forma:

$$
V_{b}(r)=k_{b}\left(r-r_{0}\right)^{2}
$$

onde $k_{b}$ é a constante de força, $r$ é a separação entre os átomos $i$ e $j$ e $r_{0}$ é a distância de equilíbrio entre esses átomos.

Para moléculas com pelo menos três átomos, a deformação do ângulo entre ligações formadas entre os pares de átomos $i$ e $j$ e $j$ e $k$ também é considerado no campo de força. Esse potencial também é harmônico e é dado por:

$$
V_{a}(\theta)=k_{\theta}\left(\theta-\theta_{0}\right)^{2}
$$

sendo $k_{\theta}$ a constante de força associada a deformação angular, $\theta$ o angulo formado entre os átomos $i, j$ e $k(\underline{3.1}(\mathrm{~b}))$ e $\theta_{0}$ o ângulo de equilíbrio entre esses átomos.

Tipicamente, simulações com moléculas biológicas são conduzidas a temperatura ambiente e não há formação ou quebra de ligações químicas. Nessas condições, os comprimentos e ângulos de ligações permanecem próximos de seus valores de equilíbrio, assim, o uso de potencias harmônicos para o estiramento e deformação angular de ligações é uma aproximação válida.

Na figura 3.1(c) estão representadas as torções diedrais. As torções envolvem 4 átomos ligados sucessivamente e são modeladas por uma soma de cossenos com a forma

$$
V_{t}(\phi)=\sum_{n} k_{\phi_{n}}\left[1+\cos \left(n \phi-\delta_{n}\right)\right]
$$

onde $k_{\phi_{n}}$ é a constante relacionada à altura da barreira potencial, $\mathrm{n}$ é a multiplicidade, que 
determina o número de pontos mínimos na curva ao rotacionar a ligação completamente, $\phi$ é o valor do ângulo diedro e $\delta_{n}$ é o valor do ângulo de fase, que determina quando o ângulo torsional passa por uma ponto de mínimo.

Além desses três principais termos, estão inclusos no campo de força CHARMM outros dois termos: o potencial de Urey-Bredley e as torções impróprias. O potencial de Urey-Bredley é um termo cruzado entre dois átomos separados por duas ligações, utilizado para restringir o movimento dos átomos que formam tais ligações. Já as torções impróprias são usadas para tratar distorções fora do plano, como as que ocorrem nos hidrogênios aromáticos, por exemplo. Os dois termos são harmônicos e têm a forma:

$$
\begin{gathered}
V_{U} B=k_{U B}\left(u-u_{0}\right)^{2} \\
V_{I}=k_{I}\left(\phi-\phi_{0}\right)^{2}
\end{gathered}
$$

onde $u$ é a distância entre os átomos $i$ e $k$ (3.1(b)), $u_{0}$ a distância de equilibrio, $\phi$ o ângulo diedro impróprio formado pelos quatro átomos ligados entre si e $\phi_{0} \circ$ angulo de equilibrio. Dessa forma, o potencial que traduz as interações intramoleculares, $V^{\text {Intra }}$ é dado por:

$$
\begin{aligned}
V^{\text {Intra }}=\sum_{\text {lig }} k_{b}\left(r-r_{0}\right)^{2} & +\sum_{a n g} k_{\theta}\left(\theta-\theta_{0}\right)^{2}+\sum_{\text {died }} \sum_{n}\left[1+\cos \left(n \phi-\delta_{n}\right)\right]+ \\
& +\sum_{U B} k_{U B}\left(u-u_{0}\right)^{2}+\sum_{I} k_{I}\left(\phi-\phi_{0}\right)^{2}
\end{aligned}
$$

Além dos potenciais envolvendo átomos ligados covalentemente, os campos de força tratam também das interações entre átomos não ligados. Essa interação é descrita pela soma dos potenciais de Coulomb e de Lennard-Jones:

$$
V^{\text {Inter }}=\sum_{i, j} 4 \epsilon_{i, j}\left[\left(\frac{\sigma_{i, j}}{r_{i, j}}\right)^{-12}-\left(\frac{\sigma_{i, j}}{r_{i, j}}\right)^{-6}\right]+\sum_{i, j} \frac{q_{i} q_{j}}{4 \pi \epsilon_{0} r_{i, j}}
$$

O primeiro termo da equação 3.1.9 é o potencial de Lennard-Jones e descreve as interações de van der Waals entre dois átomos $i$ e $j$ separados por uma distancia $r_{i, j}$. O termo dependente de $r_{i, j}^{-12}$ representa a repulsão de curto alcance provocada pela sobreposição das nuvens eletrônicas dos dois átomos. Já o termo proporcional a $r_{i, j}^{-6}$ está associado com as intereções de London. Assim, o potencial de Lennard-Jones é uma combinação de um termo repulsivo com um termo atrativo. A parte repulsiva, por ser dependente de $r^{-12}$, é relevante 


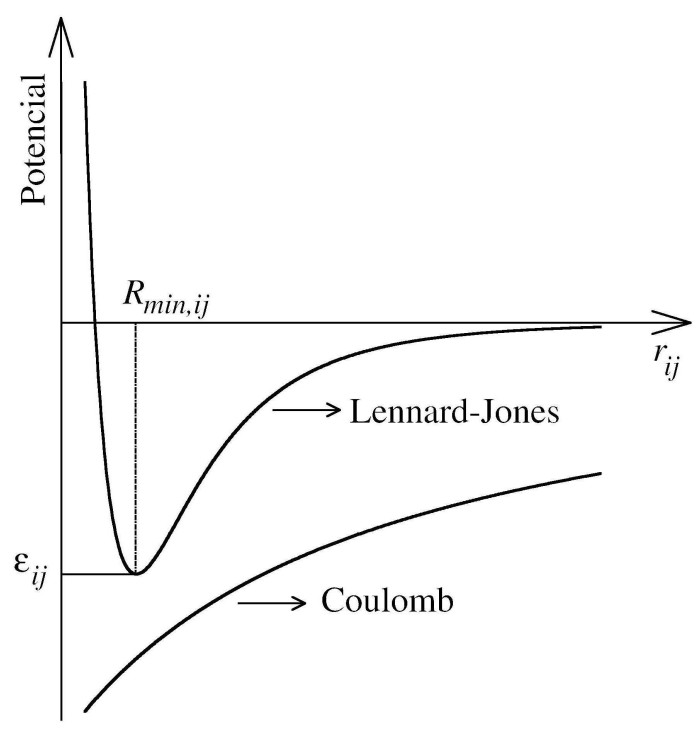

Figura 3.2 - Representação gráfica dos potenciais de Lennard-Jones e de Coulomb. Enquanto o potencial de Coulomb decai lentamente, o potencial de Lennard-Jonnes é de curto alcance e tem a forma de um poço de potecial, por ser formado pela combinação de $u$ termo repulsivo com outro atrativo.

apenas para pequenas separações interatômicas, entretanto, o termo atrativo, dependente de $r^{-6}$, domina o potencial em distâncias maiores. Essa combinação faz com que o potencial de Lennard-Jones tenha a forma de um poço de potencial, como mostrado na figura 3.2.

O segundo termo da equação 3.1 .9 descreve as interações eletrostáticas entre o par de átomos $i$ e $j$, com cargas parciais $q_{i}$ e $q_{j}$, respectivamente, e separados por uma distância $r_{i, j}$. Na figura 3.2, observa-se que o potencial de Lennard-Jones decai muito mais rapidamente que o potencial de Coulomb, com o aumento da separação interatômica. Por isso, as interações de Lennard-Jones são consideradas de curto alcance e as interações eletrostáticas de longo alcance.

\subsection{Configurações e velocidades iniciais}

Antes de começar uma simulação de dinâmica molecular é necessário definir uma configuração inicial para o sistema. Essa etapa deve ser feita de forma cuidadosa, uma vez que o arranjo inicial pode determinar o sucesso de uma simulação. Para sistemas complexos, como soluções proteicas, a configuração inicial pode ser obtida a partir de técnicas experimentais como difração de raio- $X$ ou ressonância magnética, ou a partir de modelos teóricos, como 
modelos gerados por estudos por homologia (47). No banco de dados Protein Data Bank (PDB) é possível encontrar as coordenadas atômicas da estrutura tridimensional de diversas moléculas biológicas. Entretanto, muitas vezes, as estruturas depositadas apresentam algumas falhas, como a falta de loops ou de partes de cadeia laterais de aminoácidos, e é necessário complementa-las. Além disso, as coordenadas dos átomos de hidrogênios não podem ser obtidas por difração de raio-X, devido sua baixa densidade eletrônica, assim, esses devem ser adicionados de acordo com a geometria de cada resíduo (comprimento de ligação, ângulos e diedros). Por fim, para completar a caixa de simulação, adicionam-se moléculas de água e íons, de modo a tentar reproduzir a concentração fisiológica e a neutralidade de cargas do sistema.

As simulações de MD, requerem, além das posições iniciais, as velocidades iniciais para cada átomo do sistema. As velocidades iniciais são geradas aleatoriamente segundo a distribuição de Maxwell-Boltzmann para a temperatura de interesse:

$$
p\left(v_{i x}\right)=\left(\frac{m_{i}}{2 \pi k_{B} T}\right)^{1 / 2} \exp \left[-\frac{1}{2} \frac{m_{i} v_{i x}^{2}}{k_{B} T}\right]
$$

A equação de Maxwell-Boltzmann fornece a probabilidade de um átomo $i$ de massa $m_{i}$ ter a velocidade $v_{i x}$ na direção $x$ a uma temperatura $T$.

\subsection{Equações de movimento}

Conhecendo como todas as partículas de um sistema interagem entre si e as posições e velocidades iniciais de cada átomo, é possivel obter a trajetória das partículas ao longo do tempo. O mecanismo necessário é simples, em princípio. A resolução do movimento ao longo do tempo de um sistema sob influência de um campo de força clássico específico é dada pela equação de movimento de Newton. Assim, a equação de movimento para cada átomo é dada por:

$$
m \ddot{\mathbf{r}}(t)=\mathbf{F}(t)
$$

onde $m$ é a massa do átomo e a força $\mathbf{F}$ é dada por: 


$$
\mathbf{F}(t)=-\nabla V^{\text {Total }}(t)
$$

Conhecendo a força que atua em cada átomo e sua equação de movimento, a integração pode ser realizada em pequenos estágio intermediários, separados por um intervalo de tempo fixo $\delta t$. A partir da força, é possivel calcular a aceleração de cada partícula no instante $t$, que é então combinada com a posição e velocidade da partícula no mesmo instante para calcular a posição e a velocidade no instante seguinte $t+\delta t$. A força sobre a partícula na nova posição é então determinada, fornecendo as novas coordenadas no instante $t+2 \delta t$, e assim sucessivamente (48).

Existem vários algoritmos para integração da equação de movimento utilizando esse principio. Em especial, destaca-se o algoritmo Verlet. Esse algoritmo utiliza a posição e a aceleração em um instante de tempo $t$ e a posição em um instante anterior, $\mathbf{r}(t-\delta t)$ para calcular a nova posição no instante $t+\delta t$. Para isso, as posições nos instantes $t+\delta t$ e $t-\delta t$ são descritas como uma expansão da série de Taylor:

$$
\begin{aligned}
& \mathbf{r}(t+\delta t)=\mathbf{r}(t)+\frac{d \mathbf{r}(t)}{d t} \delta t+\frac{1}{2} \frac{d^{2} \mathbf{r}}{d t^{2}} \delta t^{2}+\frac{1}{6} \frac{d^{3} \mathbf{r}}{d t^{3}} \delta t^{3}+O\left(\delta t^{4}\right) \\
& \mathbf{r}(t-\delta t)=\mathbf{r}(t)-\frac{d \mathbf{r}(t)}{d t} \delta t+\frac{1}{2} \frac{d^{2} \mathbf{r}}{d t^{2}} \delta t^{2}-\frac{1}{6} \frac{d^{3} \mathbf{r}}{d t^{3}} \delta t^{3}+O\left(\delta t^{4}\right)
\end{aligned}
$$

Somando as equações 3.3 .3 e 3.3.4 temos:

$$
\mathbf{r}(t+\delta t)=2 \mathbf{r}(t)+\frac{d^{2} \mathbf{r}}{d t^{2}} \delta t^{2}-\mathbf{r}(t-\delta t)+O\left(\delta t^{4}\right)
$$

A equação 3.3 .5 mostra como é possivel obter a posição no instante $t+\delta t$ conhecendo apenas as posições nos dois instantes anteriores $(t$ e $t-\delta t)$ e a aceleração em $t$. A velocidade em $t$ pode ser obtida subtraindo as equações 3.3 .3 e 3.3 .4

$$
\mathbf{v}(t)=\frac{\mathbf{r}(t+\delta t)-\mathbf{r}(t-\delta t)}{2 \delta t}+O\left(\delta t^{2}\right)
$$

Embora o algoritmo Verlet forneça a posição no tempo $t+\delta t$ com um erro da ordem de $\delta t^{4}$, o erro associado às velocidades é da ordem de $\delta t^{2}$, o que não é muito satisfatório. Além disso, segundo a equação 3.3.6, para determinar a velocidade em um instante $t$ é necessário conhecer anteriormente a posição em $t+\delta t$ (45-46). 
Por essas desvantagens, uma variante do algoritmo Verlet foi desenvolvida. Esse novo algoritmo, chamado Velocity-Verlet, fornece posições, velocidades e acelerações para o mesmo instante, sem comprometer a precisão. O algoritmo consiste no calculo das posições usando expansões de Taylor de segunda ordem. Já as velocidades no instante $t+\delta t$ são obtidas pela velocidade no instante $t$ e pela média das acelerações nos instantes $t$ e $t+\delta t$ (47):

$$
\begin{gathered}
\mathbf{r}(t+\delta t)=\mathbf{r}(t)+\delta t \mathbf{v}(t)+\frac{1}{2} \delta t^{2} \mathbf{a}(t) \\
\mathbf{v}(t+\delta t)=\mathbf{v}(t)+\frac{1}{2} \delta t[\mathbf{a}(t)+\mathbf{a}(t+\delta t)]
\end{gathered}
$$

A propagação das posições no algoritmo Velocity-Verlet é equivalente a propagação no algoritmo Verlet, no entanto, as velocidades são calculadas com uma precisão maior. Devido essas vantagens, o algoritmo Velocity-Verlet é um dos mais utilizados em simulações de dinâmica molecular

\subsection{Ensembles}

Um ensemble é um grande conjunto de réplicas de um sistemas cuja diferença entre as réplicas se encontra nos valores das coordenadas e dos momentos das partículas. Dessa forma cada réplica ocupa uma região no espaço de fases. Para um sistema ergótico, ou seja, um sistema para o qual a evolução no tempo faz qualquer réplica percorrer todas as configurações no espaço de fase com igual propabilidade, a média temporal, pode ser substituída pela média do ensemble.

A escolha do ensemble deve ser efetuada de acordo com as propriedades que se deseja calcular. Durante uma simulação é possivel manter constantes alguns parâmetros macroscópicos, como o número de partículas $(N)$, a temperatura $(T)$, a energia $(E)$, a pressão $(P)$ e o volume (V) . Estes parâmetros, quando fixados em conjunto, irão originar diferentes ensembles. Os ensembles mais comuns são o micro-canônico (NVE), que corresponde a um sistema isolado, o ensemble canônico (NVT), correspondente a um sistema fechado, mas não isolado e o ensemble isotérmico-isobárico (NPT), que corresponde a um sistema fechado, mas que pode realizar trabalho mecânico e trocar calor com o ambiente.

As equações de movimentos para cada partícula do sistema, como descritas na seção ante- 
rior são completas apenas para o ensemble micro-canônico. Para descrever o movimentos das partículas nos demais ensembles as equações de movimento devem ser modificadas de forma a gerar trajetórias correspondentes ao ensemble de interesse. Existem diversos algoritmos capazes de modificar as equações de movimento para reproduzir um determinado ensemble. A seguir serão descritos brevemente os algoritmos utilizados neste trabalho para manter a temperatura e a pressão constantes.

\subsubsection{Controle da Temperatura}

Todas as simulações realizadas nesse trabalho, foram realizadas no ensemble NPT. Para o controle de temperatura foi utilizada a dinâmica de Langevin, implementada no software NAMD (49). Este método consiste em adicionar forças de fricção e forças randômicas à equação de movimento de cada partícula. Assim, a equação de movimento para cada átomo assume a seguinte forma:

$$
m_{i} \ddot{\mathbf{r}}_{i}=-\nabla_{r_{i}} V(\mathbf{r})-m_{i} \gamma \dot{\mathbf{r}}_{i}+R_{i}(t)
$$

onde $\gamma$ é o coeficiente de fricção e $R(t)$ é a força aleatória. A força aleatória possui média nula e é descorrelacionada em tempos diferentes, ou seja:

$$
\begin{gathered}
\langle R(t)\rangle=0 \\
\left\langle R(t) R\left(t^{\prime}\right)\right\rangle=2 \gamma k_{B} T m \delta\left(t-t^{\prime}\right)
\end{gathered}
$$

onde $K_{B}$ é a constante de Boltzmann.

Essas forças adicionais representam um banho térmico ao qual o sistema é acoplado. A intensidade do acoplamento é proporcional ao coeficiente de fricção $\gamma$ (48).

\subsubsection{Controle da Pressão}

Em simulações realizadas no ensemble NPT, o volume é tido como uma variável dinâmica, capaz de flutuar, enquanto a pressão é mantida fixa. Para o controle da pressão, está im- 
plementado no NAMD um método que é uma combinação do método de Nosé-Hoover (49) com a dinâmica de Langevin. Essencialmente, é adicionado ao conjunto coordenada, massa e coeficiente de fricção, associado com o controle de temperatura, $\left(x_{t}, m_{t}, \gamma_{t}\right)$ um novo conjunto de variáveis associadas ao controle da pressão, $\left(x_{p}, m_{p}, \gamma_{p}\right)$.

O métode Hoover é baseado na adição de grau de liberdade extra que realiza o papel de um pistão externo acoplado ao sistema. O volume, que pode variar durante a simulação, atua como esse grau de liberdade adicional. A dinâmica de Langevin é utilizada para controlar as flutuações no barostato, ou seja, à equação de movimento do pistão são adicionados um termo de fricção e uma força aleatória. Esses termos têm o efeito de amortecer o movimento do pistão, que, no método de Hoover, está completamente livre para oscilar.

\subsection{Etapas envolvidas na simulação}

\subsubsection{Minimização}

Antes de se iniciar uma simulação de dinâmica molecular, o sistema deve ser minimizado para eliminar maus contatos entre os átomos ou torsões locais que tornam a simulação instável por gerar enormes potenciais repulsivos. Assim, a etapa de minimização de energia consiste em variar as coordenadas de cada partícula do sistema caminhando na direção onde a energia decresce. Através do ajuste nas posições atômicas, distorções nas ligações entre átomos e angulos entre ligações são corrigidos. Vários algoritmos de minimização estão disponíveis, entretanto os mais utilizados em simulações envolvendo sistemas biológicos são o Steepest Descent e o Método dos Gradientes Conjugados (47).

\subsubsection{Simulação}

As condições iniciais, geralmente, estão distantes das condições termodinâmicas desejadas. Assim, os primeiros passos de uma simulação de dinâmica molecular constituem a etapa de "equilibração", onde propriedades como temperatura, pressão e energia interna oscilam em valores distantes dos valores médios termodinâmicos. Quando as condições termodinâmicas 
são atingidas, iniciam-se as simulações de produção. As análises são realizadas em relação a essa última etapa. A etapa de produção será tão extensa quanto for necessário para estudar as propriedades de interesse. 


\section{CAPÍTULO 4}

\section{Dinâmica de hélice 12 do PPAR $\gamma$}

As estruturas cristalográficas de LBDs de PPAR $\gamma$ na sua forma apo, ligado a agonistas totais ou parciais e a antagonistas, revelam diferenças estruturais que estão associadas ao seu mecanismo de ativação e desativação. Entretanto, dados cristalográficos ocultam propriedades dinâmicas do sistema, importantes para função dos receptores nucleares. Dessa forma, estudos complementares, como experimentos de anisotropia de fluorescência e troca hidrogênio/deutério, buscam compreender o papel desse caráter dinâmico dos receptores na sua função.

Embora tenha sido possível obter informações que relacionam a dinâmica da hélice 12 do PPAR $\gamma$ com a presença de ligantes através de estudos experimentais, a análise desses dados não são suficientes para propor um modelo detalhado desse movimento. Nesse contexto, simulações computacionais, em especial, simulações de dinâmica molecular, apresentam-se como uma importante ferramenta, fornecendo informações dinâmicas do sistema, difíceis de investigar experimentalmente. Os estudos apresentados nesse capítulo tiveram como objetivo utilizar simulações de dinâmica molecular, juntamente com resultados experimentais existentes, para construir um modelo microscópico para os movimentos da hélice 12.

\subsection{Anisotropia de fluorescência}

O conhecimento da mobilidade de proteínas, principalmente da sua dinâmica conformacional, é importante para a compreensão das propriedades físicas e biológicas dessas moléculas. Por esse motivo, diversas técnicas, tanto experimentais quanto teóricas são utilizadas para estudar esses movimentos, em especial, aquelas capazes de descrever movimentos nas escalas de tempo de picossegundos a microssegundos. Técnicas como ressonância magnética nuclear, ressonância paramagnética eletrônica e anisotropia de fluorescência têm sido usadas com esse 
objetivo (48-49).

Espectroscopia de fluorescência, utilizando a fluorescência de aminoácidos naturais ou, principalmente, utilizando marcadores fluorescentes em regiões específicas tornou-se uma ferramenta bem estabelecida para investigar a dinâmica de proteínas. Em especial, experimentos de anisotropia de fluorescência resolvida no tempo são usados para estudar a dinâmica de um fluoróforo acoplado a uma proteína. Uma vez que a dinâmica desse marcador é afetada pelo movimento do fragmento proteico ao qual ele foi ligado, é possível obter informações sobre estrutura e mudanças conformacionais locais, assim como sobre a flexibilidade da proteína (50).

A anisotropia de fluorescência baseia-se no fato de que quando pequenas moléculas fluorescentes são excitadas com luz plano-polarizada emitem luz também polarizada. A polarização diminui a medida que os fluoróforos se reorientam em solução antes da emissão por fluorescência. Experimentalmente, um conjunto de moléculas fluorescentes, usadas como sonda, é excitado utilizando um curto pulso de luz polarizada. Após um intervalo de tempo, $t$, durante o qual os fluoróforos difundem-se rotacionalmente, a polarização da luz emitida é medida. A luz emita por cada molécula apresenta polarização diferente da luz original, devido à reorientação espacial do fluoróforo. A anisotropia de fluorescência $r(t)$ em um tempo $t$ é definida como:

$$
r(t)=\frac{I_{\|}(t)-I_{\perp}(t)}{I_{\|}(t)+2 I_{\perp}(t)}
$$

onde $I_{\|}$e $I_{\perp}$ são as intensidades medidas paralela e perpendicular, respectivamente, em relação à polarização da luz incidente. É possível reescrever a expressão para a anisotropia de fluorescência em termos dos momentos de dipolo de absorção e emissão da molécula fluorescente. Assumindo um conjunto de fluoróforos com orientação inicial isotrópica, $r(t)$ é dada pela função de correlação:

$$
r(t)=\frac{2}{5}\left\langle P_{2}\left[\mu_{a}(0) \cdot \mu_{e}(t)\right]\right\rangle
$$

sendo $\mu_{a}$ e $\mu_{e}$ vetores normalizados orientados nas direções dos momentos de dipolo de absorção e de emissão, respectivamente e $P_{2}(x)=\frac{1}{2}\left(3 x^{2}-1\right)$ é o polinômio de Legendre de segunda ordem (51).

A equação 4.1.2 mostra que a anisotropia de fluorescência depende exclusivamente da 
relação entre a orientação do dipolo de absorção na incidência e o dipolo de emissão no instante $t$. Dessa forma, é possível reproduzir experimentos de anisotropia de fluorescência utilizando simulações de dinâmica molecular. Através de trajetórias geradas a partir das simulações é obtida a orientação do momento de dipolo de absorção e emissão da sonda em função do tempo. A média que aparece na expressão da anisotropia $\left(\left\langle P_{2}\left[\mu_{a}(0) \cdot \mu_{e}(t)\right]\right\rangle\right)$ para um instante $t_{m}$ é estimada a partir da média temporal calculada ao longo de toda simulação:

$$
\left\langle P_{2}\left[\mu_{a}(0) \cdot \mu_{e}(t)\right]\right\rangle_{s} \cong(N-m)^{-1} \sum_{n=1}^{N-m} P_{2}\left[\mu_{a}\left(t_{n}\right) \cdot \mu_{e}\left(t_{n}+t_{m}\right)\right]
$$

onde $\mu_{a}$ e $\mu_{e}$ para os instantes $t_{n}$ e $t_{n}+t_{m}$, respectivamente, são calculados a partir da trajetória.

O momento de dipolo de absorção do fluoróforo utilizado nesse trabalho, está orientado parelelamente aos três aneis da sonda, como mostrado da figura 4.1(b). A diferença entre os momentos de dipolo de absorção e de emissão é dada pelo angulo $\lambda$ formando entre estes, e que leva a uma redução na anisotropia, $r(t)$, por um fator $P_{2}(\cos \lambda)$. Para $t=0$, a anisotropia inicial, é dada por $r_{0}=0,4 P_{2}(\cos \lambda)$. A partir de dados experimentais, é possivel obtemos $r_{0}$ e o angulo $\lambda$, entretanto, como buscamos apenas o comportamento da anisotropia $r(t)$ em função do tempo, e não a anisotropia inicial $r_{0}$, o cálculo da função de correlação foi feito apenas para um único vetor, $\mu(t)=\mu_{a}(t)$ e foi construído o gráfico de $r(t) / r_{0}$, de forma que as curvas de anisotropia estejam normalizadas para 1.

\subsubsection{Estudos de anisotropia de fluorescência para o PPAR $\gamma$}

Para investigar a mobilidade da hélice 12 do LBD de PPAR $\gamma$ e o efeito de duas mutações associadas à resistência severa à insulina, em 2003, Schwabe e colaboradores realizaram experimentos utilizando anisotropia de fluorescência estacionária e resolvida no tempo, para medir a mobilidade de um fluoróforo chamado Cysteína-fluoresceína (cys-fluor) ligado covalentemente à extremidade C-terminal da hélice 12. Este estudo destaca-se por ser o único experimento com medidas diretas da dinâmica dos LBDs de qualquer receptor nuclear (37).

Para uma sonda acoplada a uma proteína, como no experimento de Schwabe, o decaimento da anisotropia carrega informações que vão além da dinâmica da sonda. Tipicamente, uma curva de decaimento para uma sonda ligada a uma macromolécula possui três componentes 


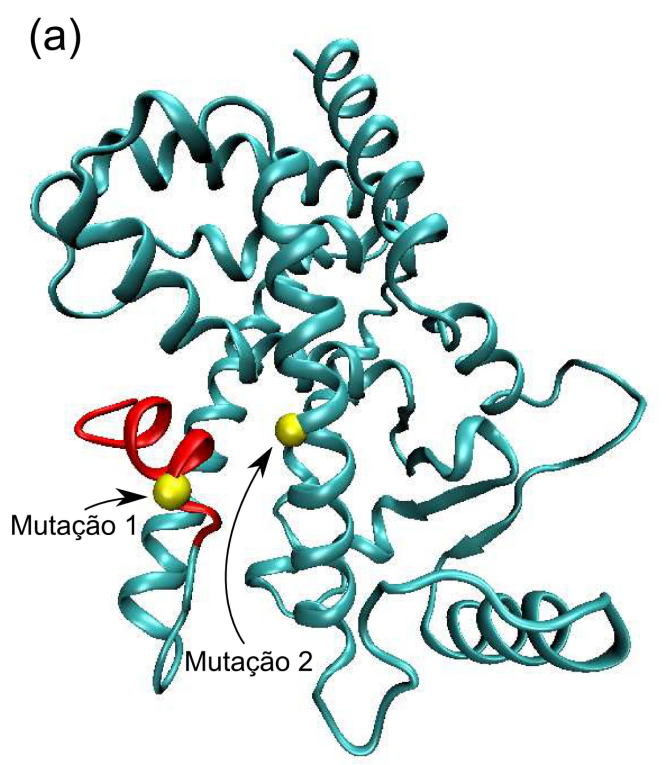

(b)

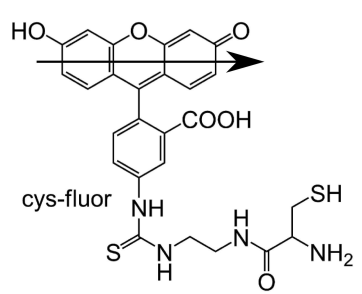

(c)

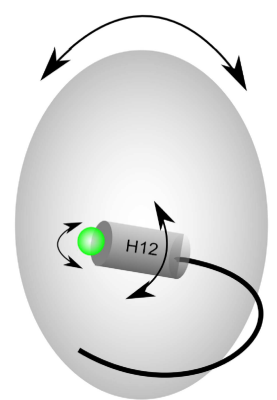

Figura 4.1 - (a) Estrutura do LBD de PPAR . As mutações localizadas em Val290 e Pro467 estão destacadas em amarelo; em vermelho está mostrada a hélice 12. (b) Estrutura da molécula fluorescente, cys-fluor, utilizada nos experimentos de anisotropia de fluorescência. (c) Visão esquemática do domínio de ligação com o ligante ilustrando os movimentos que podem ser observados através de medidas de anisotropia de fluorescência resolvida no tempo. Adaptado de (37).

com diferentes tempos de correlação, $\tau$ : uma componente rápida, associada às flutuações de curta escala espacial do fluoróforo, uma componente intermediária, relacionada com a mobilidade da região da proteína na qual a sonda foi acoplada, no caso, a hélice 12, e uma componente lenta, que carrega informações sobre a rotação da proteína como um todo (Figura 4.1(c)).

Nesse trabalho, três sistemas foram estudados para investigar o efeito do ligante: PPAR $\gamma$ na sua forma nativa e duas formas mutadas, que ocorrem naturalmente em PPAR humano e que estão associadas a uma forte desestabilização da hélice 12. A primeira mutação está localizada na região $\mathrm{N}$-terminal da $\mathrm{H} 12$, já a segunda mutação se encontra na hélice 3 e contribui para a formação da superfície que estabiliza a hélice 12 na sua posição agonista (Figura 4.1(a)). Ambas as mutações impedem a H12 de adotar sua conformação ativa.

Schwabe e colaboradores observaram que o decaimento da anisotropia foi afetado pela presença do ligante. Na ausência de ligante, tanto para o PPAR $\gamma$ nativo, quanto para os mutantes, foi verificado um decaimento mais rápido (menor tempo de correlação) que o observado na presença de ligante, confirmando, experimentalmente, a visão anterior de que o ligante estabiliza a hélice 12 na superfície do LBD.

Os tempos de correlação para o PPAR $\gamma$ nativo e mutado na posição 2 apresentaram um 
aumento significativo na presença de ligante, indicando uma redução da mobilidade. Para a estrutura mutada na posição 1, não foi demonstrado o mesmo efeito. Essa diferença observada para a segunda mutação decorre do fato de que essa mutação está localizada no início da H12 e, portanto, impede a formação uma estrutura helicoidal, conferindo uma dinâmica mais rápida para essa região C-terminal do LBD mesmo na presença do ligante.

A mobilidade da sonda acoplada a hélice 12 do PPAR $\gamma$ pode ser explicitamente simulada, através da construção do modelo completo usado por Schwabe. A dependência temporal da anisotropia de fluorescência da sonda pode ser calculada através de simulações de dinâmica molecular e ser usada para fornecer uma interpretação estrutural microscópica dos resultados experimentais. No restante do capítulo, serão descritos os detalhes das simulações realizadas e os resultados obtidos para as simulações de anisotropia de fluorescência para a sonda cys-fluor livre em água e acoplada à hélice 12 do LDB de holo-PPAR $\gamma$.

\subsection{Anisotropia de fluorescência para o cys-fluor livre em água}

A anisotropia de fluorescência está relacionada com a difusão rotacional da sonda em solução. Uma vez que simulações de dinâmica molecular são capazes de reproduzir essa difusão, é possível obter a anisotropia a partir das simulações. Entretanto, a difusão rotacional de uma molécula em solução é dependente das propriedades do solvente no qual ela se encontra. Dessa forma, é essencial utilizar uma representação da água capaz de reproduzir corretamente suas propriedades dinâmicas. Com esse propósito, foram utilizados dados experimentais da difusão da água para corrigir as propriedades dinâmicas descritas pelo modelo TIP3P. Essas correções foram utilizadas nas simulações de PPAR $\gamma$ marcado com cys-fluor.

\subsubsection{Simulações de dinâmica molecular}

Estudo anteriores comparando a anisotropia de fluorescência calculada a partir de simulações de dinâmica molecular e medida experimentalmente revelaram uma discordâncias entre os resultados. É observado que a curva de decaimento calculada tende a ser mais rápida que a medida, ou seja, pequenas moléculas em solução, quando simuladas, tendem a apresen- 
tar uma difusão rotacional mais rápida do que a observada experimentalmente. Esse efeito é bem conhecido e pode estar associado a diversos fatores, como a descrição inapropriada dos campos de força do solvente e da sonda, artefatos provocados pelas condições periódicas de contorno, tratamento inadequado das interações eletrostáticas, entre outros (48, 55-56).

A descrição inapropriada do solvente, em especial, da sua viscosidade, destaca-se como o principal fator que afeta a difusão rotacional de pequenas moléculas em solução (50). Diferentes modelos para água foram construídos nos últimos anos, sendo os mais populares os modelos TIP3P, SPC e SPC/E. Estes modelos são bastante similares, entretanto, os coeficientes para as interações de Lennard-Jones e de Coulomb apresentam pequenas divergências, resultando em diferenças nas propriedades estruturais e dinâmicas da água (52).

Nesse trabalho, o modelo TIP3P foi utilizado. Esse modelo superestima a dinâmica da água, fornecendo um coeficiente de auto-difusão superior ao experimental. Assim, foram realizadas correções, no sentido de "frear" as moléculas do solvente. O modelo TIP3P foi escolhido porque é o modelo para o qual o campo de força CHARMM foi parametrizado. Para corrigir a dinâmica difusiva da água, foi utilizado o controle de temperatura de Langevin. Como discutido no capítulo 3, esse método consiste em adicionar forças de fricção e randômicas à equação de movimento de cada átomo, sendo que o acoplamento com essas forças externas é dado pelo coeficiente de friç̧ão, $\gamma$. O coeficiente $\gamma$ afeta a viscosidade do solvente, assim, é possível escolher um valor apropriado para esse parâmetro de forma que se reproduza o coeficiente de auto-difusão da água, $D$, observado experimentalmente (48).

Para verificar o efeito de $\gamma$ na difusão da água foram realizadas cinco simulações: uma sem controle de temperatura (ensemble NVE) e as demais utilizando a dinâmica de Langevin para manter a temperatura constante (ensemble NPT), usando $\gamma=1,5,7$ e $10 \mathrm{ps}^{-1}$. Todas as simulações foram realizadas a $T=298 K$, utilizando uma caixa cúbica com lado de 30 Å contendo 826 moléculas de água e com condições periódicas de contorno. Para cada sistema, foram realizados 2000 passos de minimização, 200 ps de simulação de equilíbrio e 3 ns de simulação de produção. O coeficiente de autodifusão da água foi calculado a partir do deslocamento quadrático médio dos oxigênios, utilizando a relação de Einstein:

$$
\lim _{t \rightarrow \infty}\left\langle\left|r\left(t^{\prime}+t\right)-r\left(t^{\prime}\right)\right|^{2}\right\rangle=6 D t
$$

onde $\mathbf{r}(t)$ é a posição do átomo de oxigênio da água em um instante de tempo $t, D$ é o coeficiente de difusão da água e o símbolo $\langle\cdots\rangle$ denota a média sobre todas as moléculas.

Após a correção da dinâmica do solvente, foram realizadas simulações para o estudo 
da dinâmica da molécula de cys-fluor livre em solução. Para isso, foi simulada a difusão da sonda em água a $T=298 K$, utilizando $\gamma=10 \mathrm{ps}^{-1}$ e acoplando o banho térmico a todo o sistema (água + cys-fluor). Nessas simulações, o cys-fluor estava livre para difundir tanto translacionalmente, quanto rotacionalmente dentro de uma caixa cúbica de lado igual a 30 Å com condições periódicas de contorno (Figura 4.2(a)). Foram realizados 2000 passos de minimização, seguidos por 200 ps de simulação de equilíbrio. Posteriormente, foram realizados 20 simulações produtivas de 10 ns cada, a partir das quais foram calculadas as curvas de anisotropia de fluorescência. A anisotropia de fluorescência em função do tempo foi calculada utilizando a equação 4.1.2. Para calcular o segundo polinômio de Legendre da função de correlação foi utilizado um programa de cálculo de tempo correlação, TCF (time correlation function), desenvolvido no nosso grupo (http://Im-mdanalysis.googlecode.com).

Todas as simulações foram realizadas com o software NAMD. Os comprimentos das ligações envolvendo átomos de hidrogênio foram mantidos fixos utilizando o algoritmo RATTLE. O algoritmo Velocity-Verlet foi utilizado na resolução das equações de movimento com $\delta t=2$ fs. Para interações de curto alcance (potencial de Lennard-Jones) foi utilizado um raio de 12 Å. As interações de longo alcance (potencial de Coulomb) foram computadas via PME (Particle Mesh Ewald). Nas simulações com pressão constante, a pressão foi mantida a $1 \mathrm{~atm}$ através o algoritmo Nosé-Hoover. O período de oscilação e o tempo de decaimento foram de $200 \mathrm{fs}$ e $100 \mathrm{fs}$, respectivamente.

\subsubsection{Resultados}

A partir das simulações de água, foi calculado o coeficiente de auto difusão da água para cada sistema. A tabela 4.1 mostra os valores obtidos para cada simulação. Nota-se que para o ensemble NVE (sem controle de temperatura) e para $\gamma=1 \mathrm{ps}^{-1}$, o coeficiente de difusão da água é muito superior ao valor experimental, mostrando que para o modelo TIP3P, as moléculas de água difundem-se mais rapidamente do que o esperado. Para $\gamma=10 \mathrm{ps}^{-1}$ foi obtida a melhor concordância com o resultado experimental. A mesma estratégia de correção da dinâmica do modelo TIP3P foi utilizado com sucesso para a descrição da cinética de isomerização cis-trans de ligações peptídicas (53).

Na figura 4.2(b) estão mostradas as 20 curvas de anisotropia calculadas para o cys-fluor difundindo livremente em água utilizando $\gamma=10 \mathrm{ps}^{-1}$ (cinza) e a curva média de anisotropia (vermelho). Observa-se que as curvas de anisotropia tendem rapidamente a zero, devido a 
Tabela 4.1 - Sistemas simulados

\begin{tabular}{cccc}
\hline Sistema & Ensemble & Coeficiente de Frição, $\gamma\left(\mathrm{ps}^{-1}\right)$ & $D\left(10^{-9} \mathrm{~m}^{2} \mathrm{~s}^{-1}\right)$ \\
\hline 1 & NVE & sem controle de temperatura & 5,68 \\
2 & NPT & 1 & 4,73 \\
3 & $N P T$ & 5 & 2,82 \\
4 & $N P T$ & 7 & 2,48 \\
5 & $N P T$ & 10 & 2,32 \\
Experimental & & & 2,30 \\
\hline
\end{tabular}

rápida reoerientação do momento de dipolo da sonda em solução.

(a)

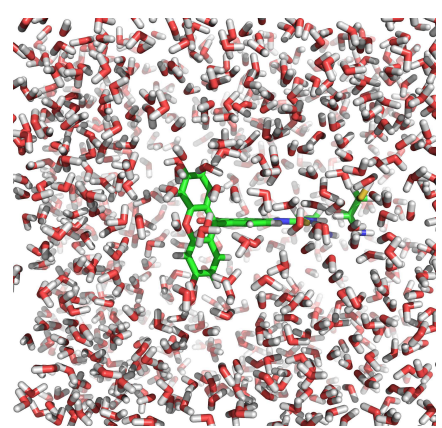

(b)

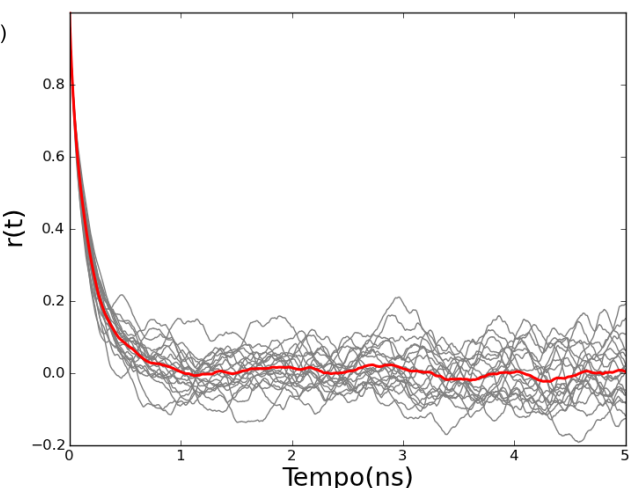

Figura 4.2 - (a) Sistema utilizado para estudar a difusão rotacional da sonda fluorescente cys-fluor.

(b) Curvas de decaimento da anisotropia de fluorescência: em cinza estão representadas as curvas obtidas para cada simulação, usando $\gamma=10 \mathrm{ps}^{-1}$ e acoplando o banho térmico a todo sistema, e em vermelho, a curva de anisotropia média.

\subsection{Anisotropia de fluorescência do complexo holo-PPAR $\gamma$ - cysfluor}

A mobilidade e a dinâmica da sonda acoplada a hélice 12 é influenciada pela presença de todo LBD. A variação da dinâmica do cysfluor na presença do PPAR $\gamma$ é governada pela estrutura e dinâmica da proteína e pode ser medida através da curva de decaimento da anisotropia. Dessa forma, é possível, entender a mobilidade do LDB, especialmente da hélice 12, através da dinâmica do cys-fluor. Nessa seção, buscou-se modelar através das simulações de MD a curva de anisotropia obtida por Schwabe para o PPAR $\gamma$ na presença de ligante. O experimento de anisotropia descrito por Schwabe foi reproduzido computacionalmente e partir desse sistema, foram calculadas diversas curvas de anisotropia, as quais foram comparadas 
com a curva experimental.

\subsubsection{Detalhes das simulações}

Todas as simulações foram realizadas usando o software NAMD. Os detalhes da construção dos sistemas, configurações iniciais, condições e etapas de simulações são descritos a seguir.

\subsubsection{Configurações iniciais}

Para o estudo da mobilidade da dinâmica de hélice 12 do LBD de PPAR $\gamma$ na presença de ligante foi utilizada a estrutura cristalográfica depositada no PDB (18), com o código 2PRG. Essa estrutura contém, além do complexo PPAR $\gamma$-Rosiglitazona (BRL), um peptídeo coativador ligado ao complexo. Entretanto, para a construção do modelo utilizado para calcular as curvas de decaimento da anisotropia, o coativador foi removido, de forma a reproduzir as condições do experimento.

Um molécula de cys-fluor foi posicionada na proximidade da hélice C-terminal do LDB e utilizando o programa psfgen, incluso no pacote NAMD, foram adicionados os átomos de hidrogênio na estrutura inicial e foi construída a ligação covalente entre o cys-fluor e o resíduo C-terminal do LBD do PPAR $\gamma$. Dessa forma, foi gerada a estruturada do PPAR $\gamma$ marcado com a sonda fluorescente na extremidade C-terminal da H12.

Para gerar diferentes configurações iniciais, foi realizada uma simulação em alta temperatura $(T=800 \mathrm{~K})$ em vácuo, mantendo todos os átomos fixos, exceto os átomos do cys-fluor. Dessa simulação foram coletadas as coordenadas de 35 frames, as quais foram submetidas a 5000 passos de minimização de energia em vácuo através do algoritmo de Gradientes Conjugados (CG) (figura 4.3). As estruturas minimizadas foram solvatadas utilizando o software Packmol (55). Cada estrutura foi colocada em uma caixa cúbica contendo 23.000 moléculas de água, e íons de sódio e cloro, para neutralizar a caixa de simulação. No total, foram adicionados 28 íons de sódio e 22 de cloro. As dimensões das caixas de simulação foram definidas de forma que a menor distância entre a proteína e o limite da caixa fosse de $15 \AA$. 


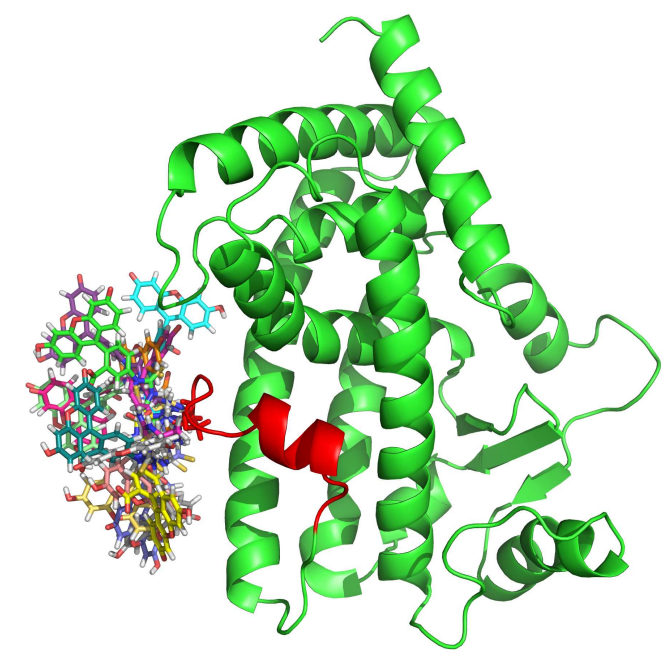

Figura 4.3 - Sobreposição de algumas configurações iniciais utilizadas nas simulações de dinâmica molecular.

\subsubsection{Preparação dos sistemas e simulações produtivas}

Cada configuração inicial passou por uma sequência de simulações de minimização de energia e dinâmica para preparar o sistema para as simulações produtivas. As etapas de preparação foram:

1. Minimização: 1000 passos mantendo a proteína, o ligante e o cys-fluor fixos;

2. Dinâmica: 200 ps mantendo a proteína, o ligante e o cys-fluor fixos;

3. Minimização: 500 passos mantendo os carbonos $\alpha$ fixos;

4. Dinâmica: 200 ps mantendo os carbonos $\alpha$ fixos;

5. Dinâmica: 2.0 ns com todo o sistema livre.

As duas primeiras etapas foram realizadas para permitir a relaxação do solvente ao redor do LBD. Já as etapas 3 e 4 foram realizadas para permitir a relaxação das cadeias laterais da proteína, sem alterar a estrutura global do LBD. Na etapa 5, foi permitida a relaxação do sistema todo.

Em seguida, para cada sistema, foram realizados 20 ns de simulação produtiva. Todas as simulações foram realizadas no ensemble NPT com $T=298 K$, utilizando dinâmica de Langevin para controle de temperatura com coeficiente de fricção igual a $10 \mathrm{ps}^{-1}$. As demais condições de simulação foram idênticas às descritas para o cys-fluor livre em água. 


\subsubsection{Resultados}

Os resultados experimentais descritos por Schwabe, revelam uma estabilização da hélice 12 na presença de agonistas. Foi observado que os tempos de decaimento da anisotropia foram menores sem ligante do que com ligante, indicando uma mobilidade mais acentuada. Embora esteja claro o efeito estabilizador do ligante na dinâmica da H12, não há uma descrição da natureza dos movimentos envolvidos. Nessa seção, através da comparação entre as curvas de anisotropia calculadas e obtidas experimentalmente, procuramos associar propriedades estruturais com diferentes níveis de mobilidade.

Como descrito na seção anterior, foram construídas 35 configurações iniciais de cys-fluor ligado ao holo-PPAR $\gamma$. A anisotropia de fluorescência em função do tempo foi calculada a partir da equação 4.1.2. Cada configuração inicial gerou uma curva de decaimento, como mostrado na figura 4.4. As curvas em cinza representam o decaimento calculado a partir de cada configuração inicial, em azul e vermelho estão mostradas as curvas experimentais normalizadas para PPAR $\gamma$ na presença e na ausência de ligante, respectivamente.

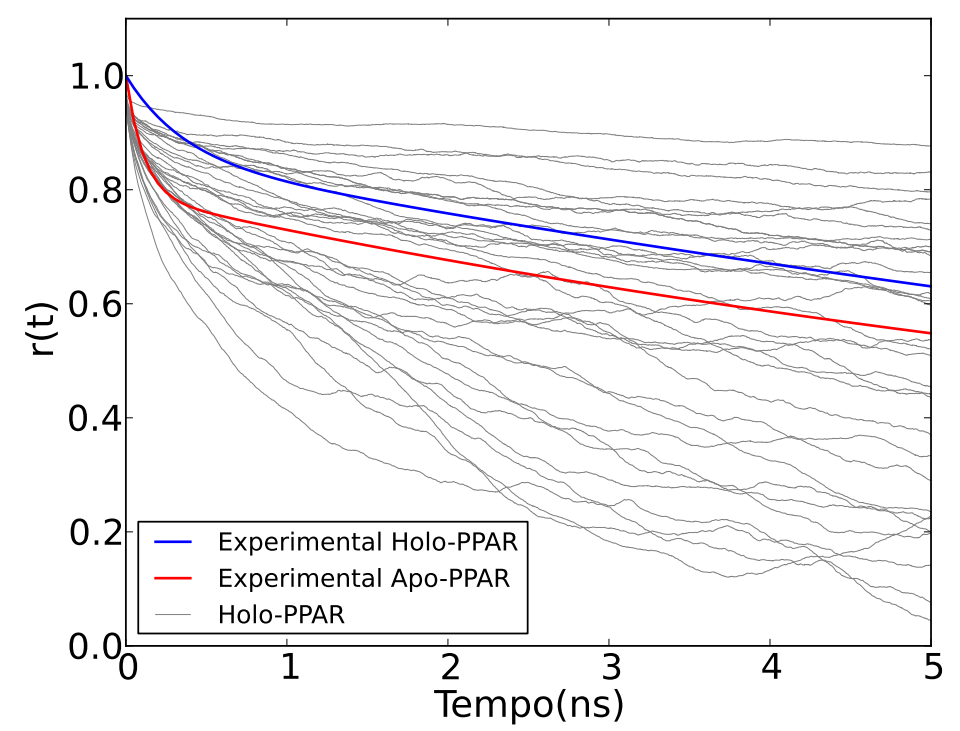

Figura 4.4 - Dependência temporal da anisotropia. Em cinza estão representadas as curvas de decaimento da anisotropria obtidas a partir de cada configuração inicial. Os decaimentos obtidos experimentalmente para holo-PPAR $\gamma$ e apo-PPAR $\gamma$ estão representados em azul e vermelho, respectivamente (37).

Na figura 4.4 é possível observar uma grande variação no comportamento da dinâmica do cys-fluor ligado ao PPAR $\gamma$ dependendo da configuração inicial adotada. É interessante observar que mesmo partindo de uma estrutura com ligante, supostamente mais rígida, foram 
obtidos comportamentos dinâmicos mais rápidos que o observado para a estrutura na ausência de ligante.

Os decaimentos obtidos experimentalmente aproximam-se das curvas teóricas com decaimento mais lento. Dessa forma, procuramos averiguar detalhadamente as estruturas contidas nas trajetórias correspondentes a cada curva de anisotropia para tentar compreender o comportamento mostrado na curva experimental.

Para isso, começamos observando as trajetórias correspondentes às curvas mais externas, ou seja, às trajetórias nas quais o cys-fluor apresenta maior e menor mobilidade. Fazendo a superposição das conformações assumidas pelo cys-fluor ao longo das trajetórias, observa-se que para a simulação correspondente à curva com decaimento mais lento, a sonda permanece presa na superfície do LBD, percorrendo uma pequena região entre as hélices 11 e 12, como mostrado na figura 4.6(a). Porém, ao observar a trajetória percorrida pelo cysfluor na simulação associada à curva com decaimento mais rápido, nota-se que a molécula de cysfluor, encontra-se "descolada" da superfície do PPAR $\gamma$, assumindo, na maior parte do tempo, uma conformação estendida em relação ao LBD (figura 4.6(d)). Para as demais curvas, é observado um comportamento intermediário, ou seja, a molécula de cysfluor flutua entre uma conformação estendida e uma conformação mais fechada em relação ao corpo do LBD. O tempo de permanência em cada conformação determina o perfil da curva de anisotropia, assim, curvas associadas a trajetórias onde o cys-fluor permanece a maior parte do tempo interagindo com a superfície do PPAR $\gamma$, apresentam um tempo de decaimento mais lento.

Para verificar o efeito da mobilidade do cys-fluor no decaimento das curvas apresentadas na figura 4.4, foram calculadas as distâncias entre o átomo de oxigênio localizado no anel central do cys-fluor e a superfície do LBD para cada simulação (figura 4.5(a)). Para facilitar a visualização, na figura 4.5(b) estão mostradas as distribuições das distâncias apenas para quatro simulações. As simulações foram escolhidas de forma a amostrar diferentes tempos de decaimento e foram nomeadas de 1 a 4 . Nota-se que curvas que apresentam um decaimento mais lento estão associadas com distribuições que apresentam picos bem definidos e localizados em menores distâncias (simulações 1 e 2). Já distribuições alargadas estão relacionadas com curvas de anisotropia que apresentam decaimentos mais rápidos (simulações 3 e 4). 
(a)

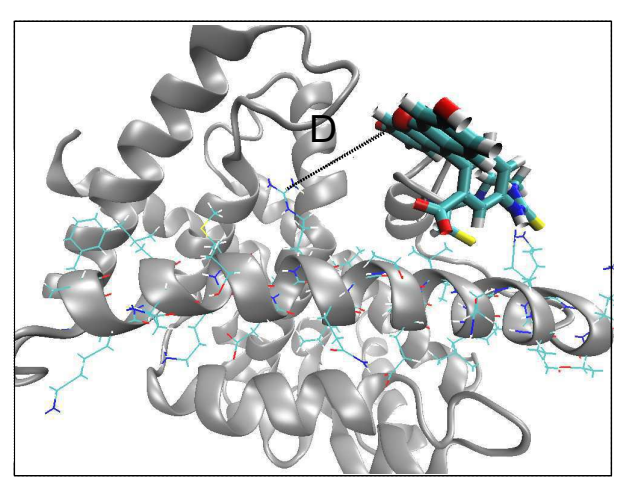

(b)

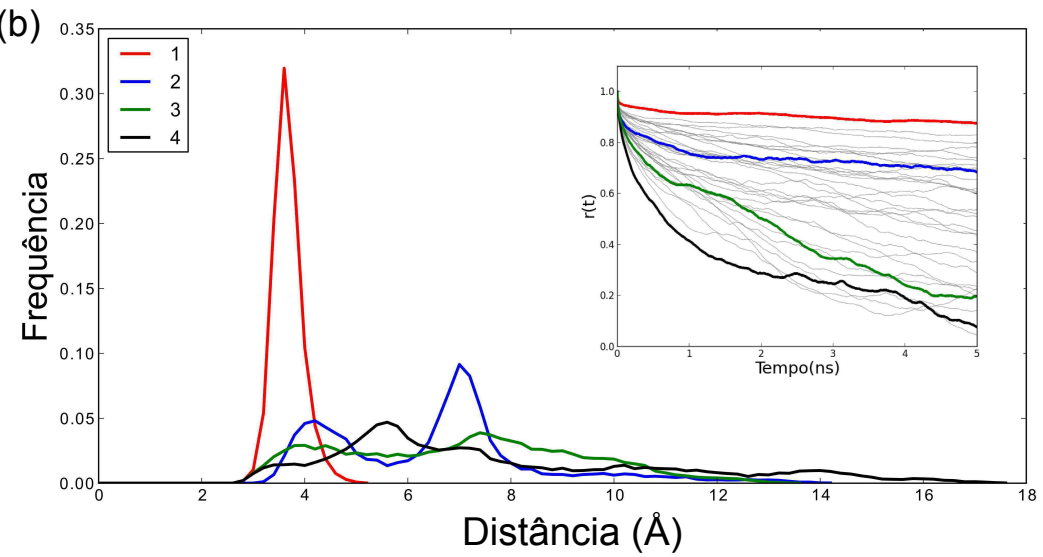

Figura 4.5 - (a) Esquema mostrando a menor distância entre o oxigênio do anel central do cys-fluor e a superfície do $L B D$. (b) Distribuição da menor distância entre o oxigênio central do cysfluor e a superfície do LBD para quatro simulações. As quatro simulações escolhidas correspondem às curvas de anisotropia destacadas em cores no gráfico interno.

A figura 4.6 mostra a superposição das conformações adotadas pelo cys-fluor nas simulações correspondentes ao decaimento mais rápido, mais lento e dois decaimentos intermediários. Nas figuras 4.6(a) e (b) (simulações 1 e 2) vemos a sonda interagindo persistentemente com a superfície do LBD. Na simulação 1, a sonda permanece durante toda simulação na região formada entre as hélices $\mathrm{H} 11$ e H12, resultando em uma curva de anisotropia com decaimento bastante lento. Efeito similar é observado na simulação 5. Nessa simulação, a sonda não está presa na região entre as hélices, mas continua interagindo fortemente com a superfície da proteína, especialmente com a hélice 11. Por não estar localizada na cavidade entre as hélices, o cys-fluor apresenta maior liberdade para se mover e, por isso, é observado um decaimento mais acentuado para a curva de anisotropia.

Por outro lado, na simulação 3 (figura 4.6(d)) a sonda exibe uma maior mobilidade se comparada com as anteriores, porém ainda mantêm a mesma orientação relativa à superfície do LBD ao longo de toda simulação. O rápido decaimento da anisotropia observado para a simulação 4 (figura 4.6(d)) ocorre uma vez que a sonda não apresenta restrições para sua 
mobilidade, exibindo flutuações com grande amplitude.

As simulações de holo-PPAR $\gamma$ indicam que as curvas de anisotropia de fluorescência em função do tempo para o cys-fluor acoplado a hélice 12 apresentam uma grande variação no tempo de decaimento, dependendo da forma como a sonda interage com a superfície do LBD. As curvas experimentais, por localizarem-se na parte superior do espectro, devem ser interpretadas como resultado da mobilidade local da sonda, sempre mantendo a interação superficial com o LBD, com os movimentos com dimensão similar ao mostrado para a simulação 2. Nossos resultados não excluem a existência de conformações onde o cys-fluor pode estar rigidamente acoplado à superfície, como na simulação 1 , ou completamente desprendido do corpo do LBD, exibindo uma mobilidade bastante intensa, como na simulação 4. Entretanto, a conformação mais frequente adotada pela sonda deve ser tal que permita interações com a superfície do LBD na mesma escala que a exibida pelo cys-fluor na simulação 2.

\subsubsection{Variação conformacional da hélice 12}

As curvas de decaimento da anisotropia para um marcador acoplado a uma região proteica refletem as propriedades dinâmicas da sonda, da porção da proteína onde a sonda foi ligada e da proteína como um todo, porém o efeito da rotação do LBD como um todo pode ser considerado o mesmo para todos os sistemas (37). O comportamento dinâmico observado para os cys-fluor pode ser estendido também para a hélice 12, ou seja, decaimentos da anisotropia mais rápidos, estão associados não só a uma dinâmica mais rápida da molécula de cys-fluor, mas também a uma maior mobilidade da hélice 12 .

A mobilidade conformacional da $\mathrm{H} 12$ foi analisada via RMSD (root mean square deviation). Primeiramente foi realizado o alinhamento de todos os frames de uma simulação, a fim de retirar desvios da posição atômica relativos à translação e a rotação da proteína. O alinhamento foi realizado utilizando os átomos da cadeia principal do LBD. O RMSD foi calculado através da seguinte equação:

$$
R M S D(t)=\left[\frac{1}{N} \sum_{i=1}^{N}\left[\mathbf{r}_{i}(t)-\mathbf{r}_{i}(0)\right]^{2}\right]^{1 / 2}
$$

onde $\mathrm{N}$ é o número de átomos considerados, $r_{i}$ é a posição do átomo $i$ no instante $t$ e $r_{j}(0)$ é a posição inicial do átomo $i$. Para o calculo de RMSD, a hélice 12 foi considerada como sendo formada pelo resíduos 465 a 477 . Na figura 4.7 estão mostrados os valores de RMSD 
Simulação 1

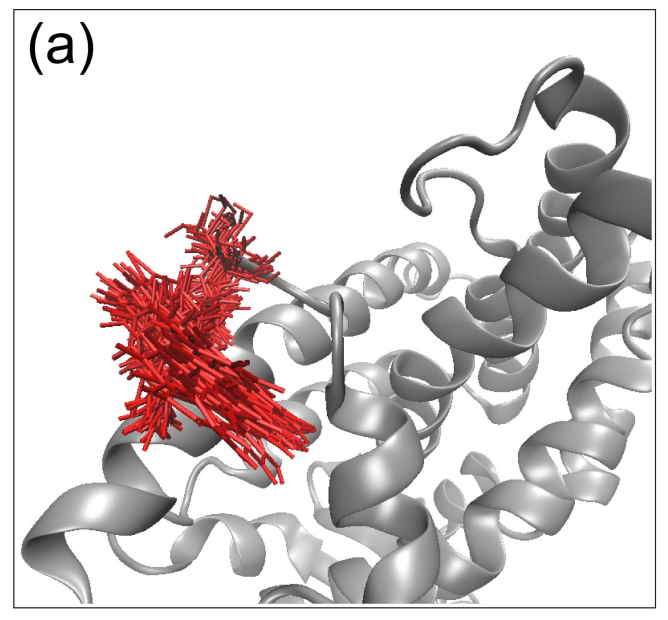

Simulação 3

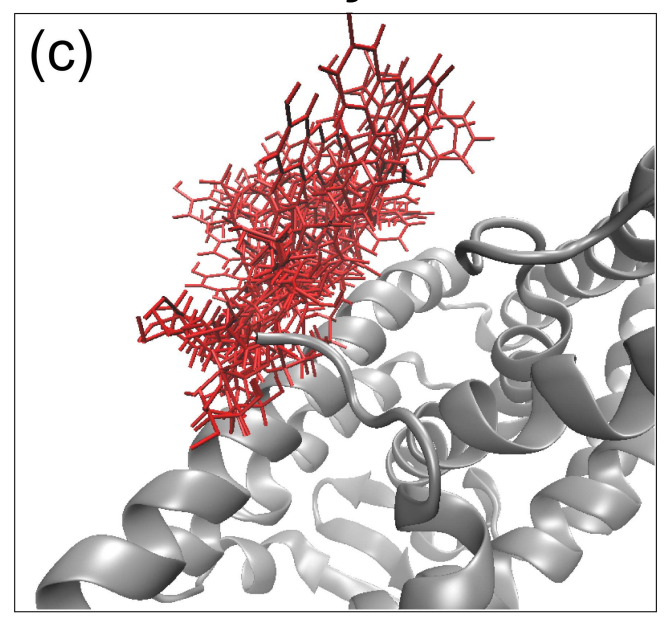

Simulação 2

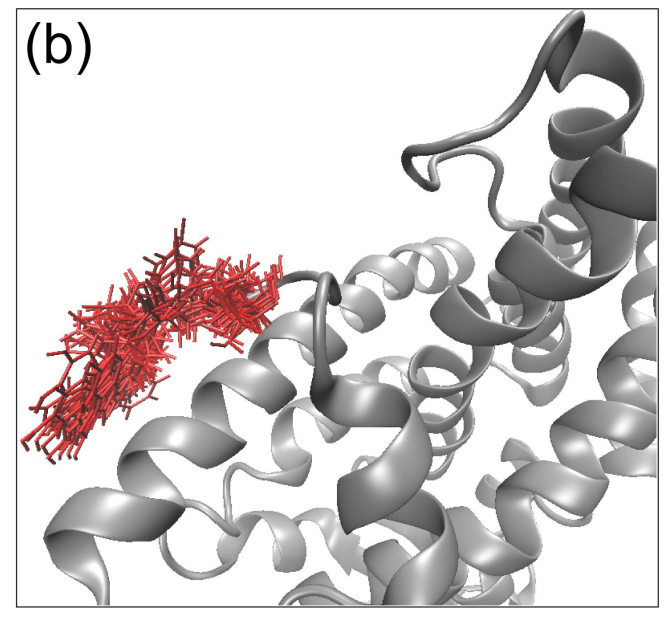

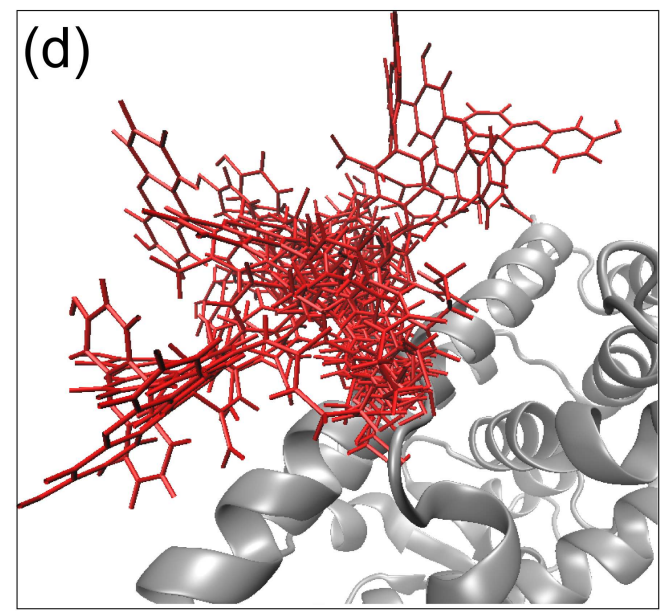

Figura 4.6 - Superposição das conformações adotadas pelo cys-fluor nas simulações 1 (a), 2 (b), 3 (c) e 4 (d). 
apenas para as simulações 1 e 4, que apresentam comportamentos extremos. Nota-se que para a simulação 1 (vermelho) não são observados grandes desvios em relação ao valor médio, ou seja, a hélice 12 apresenta uma pequena mobilidade. Já para a simulação 4 (preto), são observados dois intervalos de grande variação, onde a hélice 12 assume conformações que divergem cerca de $3 \AA$ da estrutura inicial.

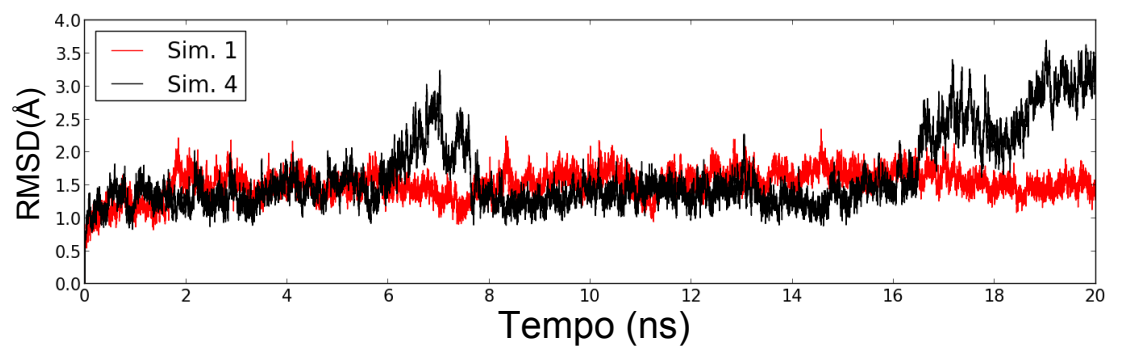

Figura 4.7 - Evolução temporal do RMSD da hélice 12 em relação à posição inicial.

Para compreender o comportamento das curvas de RMSD, observamos as trajetórias geradas para as duas simulações. Para a simulação 1 foi observado que a hélice 12 encontra-se durante toda a simulação muito próxima da conformação inicial. Essa pequena variação na posição da H12 é mostrada na figura 4.8(a). Entretanto, para a simulação 4, foi observado que a hélice 12 assume diferentes conformações, sendo que a conformação mais divergente está mostrada na figura 4.8(b). Esses resultados fornecem indícios da dimensão da mobilidade da hélice 12 do LDB do PPAR $\gamma$ na presença de um agonista total. A maior variação na conformação adotada pela hélice 12 está mostrada na figura 4.8(b). Essa estrutura está associada a uma curva de anisotropia que apresenta um decaimento muito mais rápido que o observado experimentalmente e, por isso, espera-se que a variação conformacional da $\mathrm{H} 12 \mathrm{em}$ solução seja menos intensa que a mostrada na figura 4.8(b).
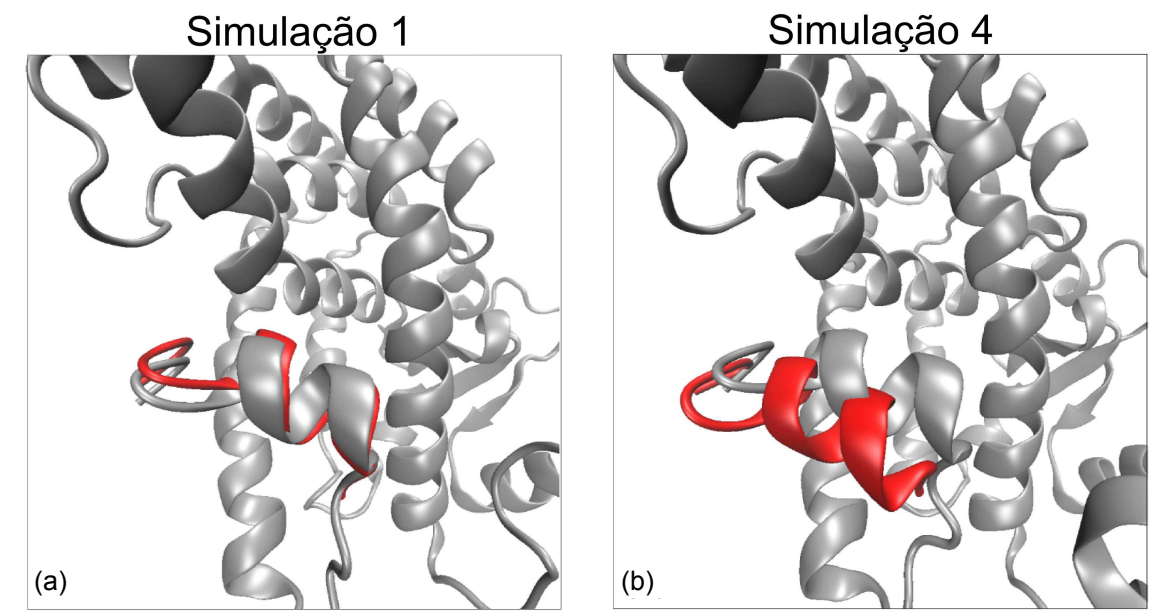

Figura 4.8 - Comparação entre a conformação inicial e a conformação associada ao maior valor de RMSD para as simulações 1 (a) e 4 (b). 
A estabilização da hélice 12 na presença de Rosiglitazona ocorre, principalmente, através de interações eletrostáticas entre o ligante e o resíduo Tyr473 da H12. Conhecendo esse mecanismo, verificamos o efeito dessa estabilização nas duas simulações com comportamentos extremos. Na tabela 4.2 estão mostradas as energias de interação entre a Tyr473 e a Rosiglitazona. Observa-se que a interação é predominantemente eletrostática, porém na simulação 1 a energia de interação é mais intensa (em módulo) que para a simulação 4. Esse resultado está de acordo com a variação conformacional observada nas duas simulações: uma interação mais fraca entre a Rosiglitazona e a Tyr473 e que oscila no tempo é resultado da maior mobilidade da $\mathrm{H} 12$.

Tabela 4.2 - Energia de interação entre o resíduo Tyr473 e a Rosiglitazona

\begin{tabular}{ccc}
\hline & Simulação 1 & Simulação 4 \\
\hline Eletrostática $(\mathrm{kcal} / \mathrm{mol})$ & $-7,01$ & $-3,75$ \\
VDW $(\mathrm{kcal} / \mathrm{mol})$ & $-0,53$ & $-1,1$ \\
Total $(\mathrm{kcal} / \mathrm{mol})$ & $-7,54$ & $-4,86$ \\
\hline
\end{tabular}

Para melhor compreensão da dimensão da mobilidade da hélice 12 em solução, foram selecionadas as oito simulações que forneceram curvas de anisotropia mais similares à curva experimental para holo-PPAR $\gamma$ e observada as conformações adotadas pela H12 nessas simulações (figura 4.9). Para todas as simulações selecionadas são observadas configurações pouco divergentes da conformação inicial, porém com variações superiores à observada para a simulação 1 e, principalmente, inferiores à observada na simulação 4. Observa-se também que não existe um sentido preferencial, ou seja, a variação conformacional da H12 ocorre tanto do sentido de aumentar ou diminuir a interação com a superfície do LBD.

(a)
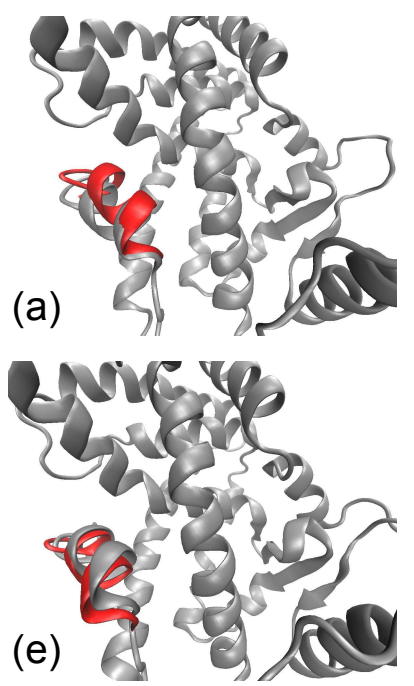
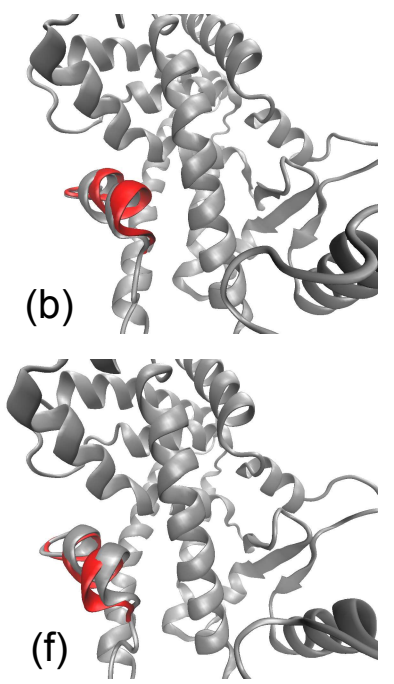
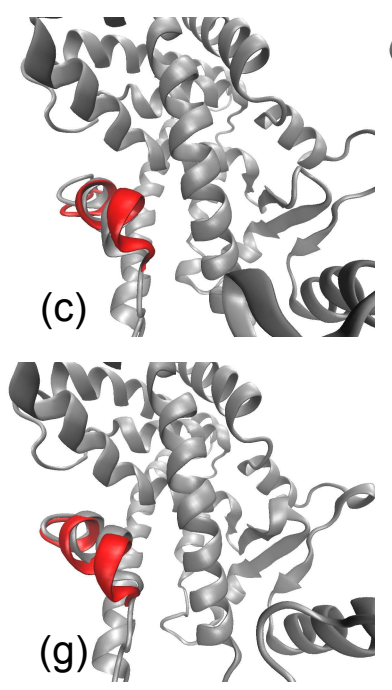
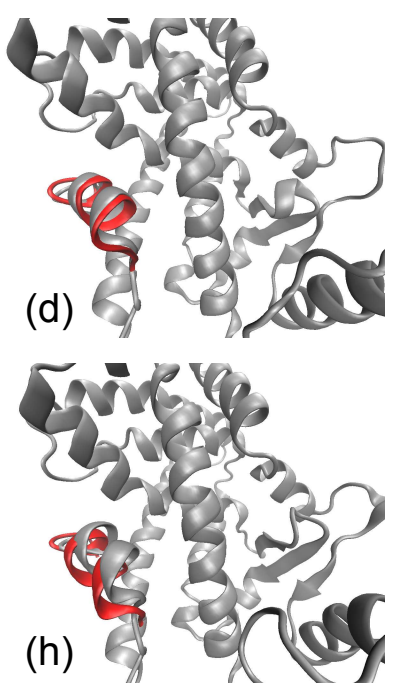

Figura 4.9 - Máxima variação conformacional adotada pela hélice 12 para as oito simulações com curvas de anisotropia mais similares à experimental. 
Embora as simulações tenham sido realizadas somente para o holo-PPAR $\gamma$, é possível dimensionar também a amplitude da hélice 12 para o $\operatorname{PPAR} \gamma$ na ausência de ligante. Uma vez que a curva de anisotropia para o apo-PPAR $\gamma$ apresenta um decaimento mais lento que o observado para a simulação 4, espera-se que a variação da H12 nessas condições não seja superior ao observado na figura 4.8(b). A maior flexibilidade da hélice 12 para receptores nucleares na ausência de ligante, deve ser, portanto, devido uma variação conformacional mais frequente que em holo receptores, porém não de maior amplitude.

Ao contrário do sugerido no mecanismo da ratoeira, nossos resultados mostram que mesmo na ausência de ligante a hélice 12 deve interagir com a superfície do LDB, já que, somente dessa forma, é possível explicar a curva de anisotropia experimental. Caso a hélice 12 adotasse uma conformação estendida, o cys-fluor estaria completamente exposto ao solvente, sem interagir com o LBD e dessa forma, a curva de anisotropia apresentaria um decaimento muito mais rápido que o observado experimentalmente. No próximo capítulo mostraremos que conformações onde a hélice 12 encontra-se aberta, e consequentemente o cys-fluor apresenta menor interação com a superfície do LDB, exibem comportamentos que não são capazes de explicar as curvas de anisotropia experimentais e, dessa forma, devem ser conformações inexistentes.

\subsection{Conclusões}

Nesse capitulo foram mostradas simulações para o estudo da dinâmica reorientacional do cys-fluor livre em solução e acoplado à hélice 12 de holo-PPAR $\gamma$. Primeiramente, foi realizada uma correção cuidadosa da dinâmica do solvente, já que esta propriedade influencia diretamente o comportamento da sonda fluorescente. Através da comparação com a curva experimental do cys-fluor difundindo livremente em água, realizamos a correção aplicando um banho de Langevin com coeficiente de fricção $\gamma=10 \mathrm{ps}^{-1}$. Esse valor de $\gamma$ mostrou-se o mais adequado para reproduzir a constante de auto-difusão da água.

As simulações de cys-fluor acoplado ao holo-PPAR $\gamma$ mostraram comportamentos distintos para a curva de anisotropia em função do tempo, dependendo da configuração inicial adotada. Entretanto, os comportamentos observados experimentalmente são similares apenas àqueles onde a sonda apresenta uma dinâmica mais lenta, devido a interação com a superfície do LDB. Simulações onde o cys-fluor apresenta liberdade de se mover sem impedimentos apresentam curvas de anisotropia com decaimento muito mais rápido que os experimentais. Assim, as 
taxas de decaimento observadas experimentalmente devem ser interpretadas como resultado de flutuações locais da sonda, sempre mantendo contado com a superfície do LBD, especialmente com a hélice 11 .

Nesse capítulo foi estudada também a dimensão da variação conformacional da hélice 12. As simulações que mais se assemelham às observações experimentais revelam uma baixíssima mobilidade da hélice 12 , permanecendo muita próxima da conformação ativa durante toda a simulação. Mesmo para simulações associadas à curvas de anisotropia com rápido decaimento, a hélice 12 não apresenta uma variação conformacional de grande amplitude. Para essas simulações, embora a H12 apresente uma maior flexibilidade, encontra-se, durante toda simulação, em conformações próximas à conformação inicial. Dessa forma, a mobilidade da hélice 12 em solução não deve ser tão intensa como a proposta pelo modelo da ratoeira, sendo resultado apenas de pequenas flutuações em torno da conformação ativa, tanto para o holo-PPAR $\gamma$ quanto para o apo-PPAR $\gamma$. 
CAPÍTULO 5

\section{Receptores Nucleares com a hélice 12}

\section{aberta}

\subsection{Modelos de PPAR $\gamma$ com a hélice 12 aberta}

O modelo da ratoeira sugere um mecanismo de entrada e saída do ligante no sítio do LBD. Nesse modelo, a hélice 12 encontra-se estendida em relação à superfície do LBD na ausência do ligante, permitindo a entrada deste. Entretanto, não existem estruturas cristalográficas de PPAR $\gamma$ com a H12 adotando tal conformação. Desse forma, para verificar o comportamento da curva de anisotropia em função do tempo para essa configuração construímos um modelo para apo-PPAR $\gamma$ com a hélice 12 em uma conformação aberta, como proposto pelo modelo da ratoeira. Esse modelo foi construído a partir da estrutura de holo-PPAR $\gamma$ (PDB: 2PRG) e utilizando simulações de SMD (Steered Molecular Dynamics).

\subsubsection{Steered Molecular Dynamics}

Importantes eventos biológicos, como a associação e dissociação de ligantes envolvem a transição de um estado de equilíbrio para outro. Entretanto eventos que envolvem o cruzamento de grandes barreiras de potencial ainda são difíceis de serem reproduzidos em simulações convencionais de dinâmica molecular, uma vez que envolvem escalas de tempo muito longas. Dessa forma, o uso de forças externas pode ser utilizado para guiar o sistema de sistema de equilíbrio para outro, acelerando o processo de transição. Nesse contexto, simulação de SMD são uma importante ferramenta no estudo de eventos que envolvem transições.

Basicamente, simulações de SMD baseiam-se em aplicar um força externa a um ou mais 
(a)

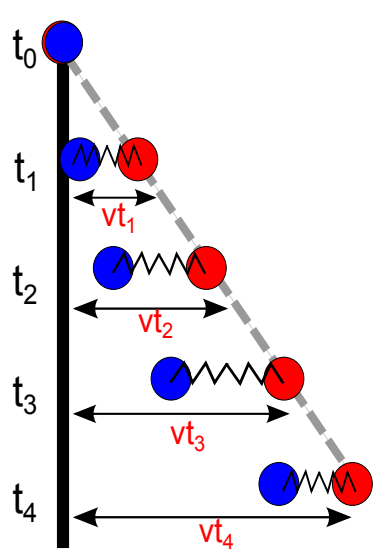

(b)

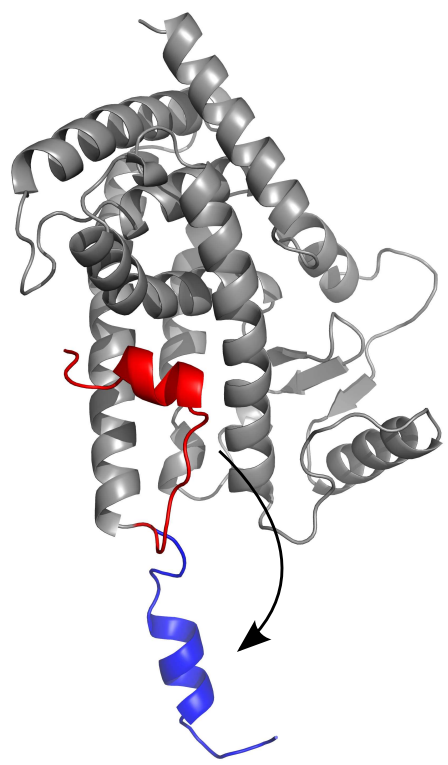

Figura 5.1 - (a) SMD com velocidade constante em uma dimensão. Em vermelho está representado o átomo virtual e em azul o átomo SMD. A medida que o átomo virtual se move com velocidade constante, o átomo SMD experimenta uma força que depende linearmente da separação entre os dois átomos. (b) Sobreposição da conformação adotada pela H12 no inicio (vermelho) e no final (azul) da simulação de SMD.

átomos, chamados de átomos SMD e manter fixos outro conjunto de átomos para estudar o comportamento da proteína em diferentes condições. Neste trabalho foram realizadas simulações de SMD com velocidade constante. Nesse tipo de simulação, aos átomos SMD é aplicada uma força que corresponde ao deslocamento de uma mola no espaço na direção desejada, com velocidade constante (figura 5.1(a) ). A força externa que atua sobre os átomos SMD á dada por:

$$
\vec{F}=k\left[\vec{v} t-\left(\vec{r}-\vec{r}_{0}\right) \cdot \vec{n}\right]
$$

onde $k$ é a constante de mola, $v$ a velocidade com que os átomos são puxados, $\vec{r}$ a posição dos átomos SMD no instante $t, \vec{r}_{0}$ a posição inicial dos átomos SMD e $\vec{n}$ a direção da força aplicada (49).

Para construir o modelo de PPAR $\gamma$ com a hélice 12 aberta, os átomos da hélice 12 foram selecionado como átomos SMD e foram puxados para fora, no sentido de formar uma conformação com a hélice 12 aberta (figura 5.1(b)). Duas simulações de SMD foram realizadas utilizando diferentes direções para a força. Cada simulação foi realizada durante 10 ns, utilizando a velocidade de puxamento igual a $3 \AA /$ ns e com uma constante de mola igual a 4 kcal mol ${ }^{-1} \AA^{-1}$.

Ao final da simulação de SMD foram obtidos dois modelos de PPAR $\gamma$ com a hélice 12 

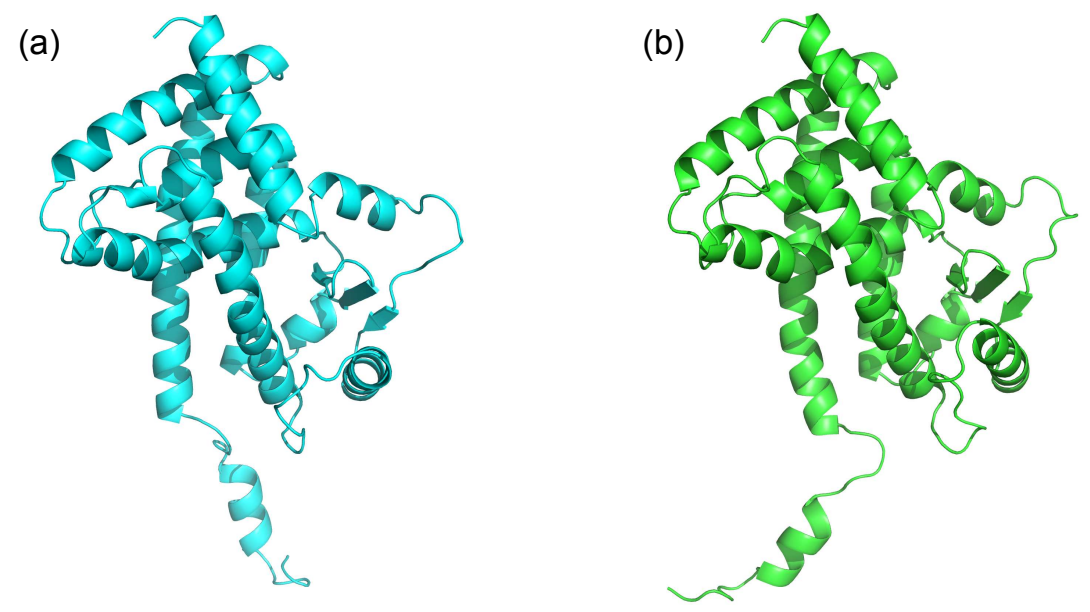

Figura 5.2 - Estruturas para apo-PPAR com a H12 aberta obtidas a partir de simulações de SMD.

aberta (5.2). A molécula de cys-fluor foi então acoplada às estruturas finais. O complexo foi submetido a uma simulação em vácuo e a alta temperatura para gerar diferentes configurações iniciais para as simulações de cálculo da função de correlação, assim como descrito na seção anterior. Das simulações a temperatura elevada foram obtidas 10 configurações iniciais que passaram pelo mesmo procedimento descrito na seção 4.3.2.1.

\subsubsection{Anisotropia de fluorescência para o apo-PPAR $\gamma$ com a $\mathrm{H} 12$ aberta}

A partir das estruturas geradas por SMD calculamos as curvas de anisotropia para as 10 configurações iniciais construídas. Na figura 5.3 estão mostradas as 10 curvas obtidas (laranja). Assim como para as simulações de PPAR $\gamma$ nativo, nota-se um comportamento diversificado para a dinâmica reorientacional do cys-fluor nesse modelo. Entretanto, de forma geral, são observadas curvas com decaimentos mais rápido que os obtidos nas simulações anteriores e, principalmente, que os experimentais.

O objetivo dessas simulações foi mostrar que uma estrutura para apo-PPAR $\gamma$ como proposto pelo modelo da ratoeira, ou seja, com a H12 desprendida da superfície do LBD, não é capaz de reproduzir os resultados experimentais. Dessa forma, nossos resultados sugerem que mesmo na ausência de ligantes, a hélice 12 deve interagir com a superfície do domínio. Esses resultados não contradizem o fato de que para apo receptores a H12 é mais móvel que para 
holo receptores, porém indicam que a variação conformacional da hélice 12 deve ocorrer em torno em de uma estrutura onde a hélice permanece interagindo com a superfície do LBD. Se existentes, estruturas que apresentam a $\mathrm{H} 12$ aberta devem ser fracamente populadas e não devem apresentar nenhuma função no associação ou dissociação de ligantes ou no recrutamento de correguladores.

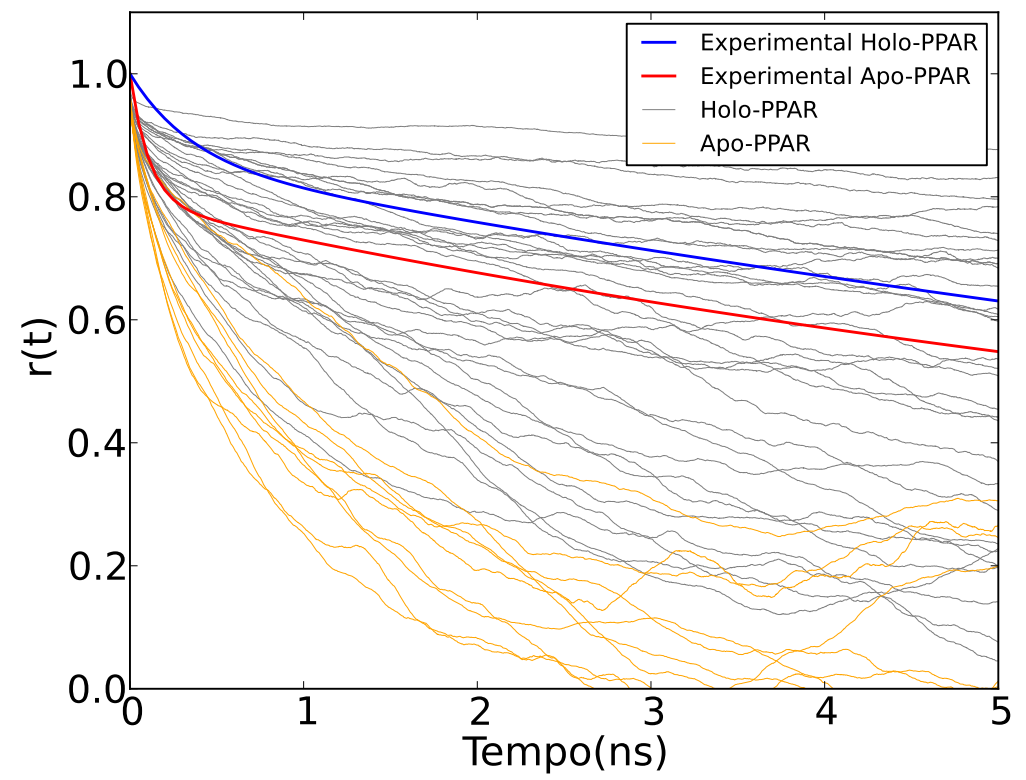

Figura 5.3 - Comparação entre as curvas de anisotropia para o PPAR : em cinza estão representadas as 35 curvas obtidas para o holo-PPAR $\gamma$ nativo, em laranja as 10 curvas para os modelos de apo-PPAR com a H12 aberta; em azul e vermelho as curvas experimentais para o PPAR na presença e na ausência de ligante, respectivamente.

Na figura 5.3 é observada a existência de uma curva de anisotropia para o modelo de PPAR $\gamma$ com a hélice 12 aberta com um decaimento mais lento que as demais curvas obtidas para esse modelo. Ao observar o comportamento da sonda nota-se que esta se encontra durante toda simulação dobrada sobre a hélice 12, como mostrado na figura 5.4(a), sofrendo apenas pequenas alterações conformacionais em torno dessa estrutura e justificando o decaimento observado. Em geral, para as demais simulações, o cys-fluor percorre diferentes conformações em torno da H12, resultando em curvas de anisotropia com decaimentos rápidos (figura 5.4(b)). Essa curva com decaimento mais lento poderia sugerir que com uma maior amostragem, ou seja, um número maior de simulações, seria possivel observar outras configurações que apresentem decaimentos similares, entretanto, ao avaliar a posição adotada pela sonda durante a simulação, ve-se que esse é um caso extremo, onde a sonda possui uma dinâmica reorientacional bastante limitada. Dessa forma, mesmo com um número maior de simulações não devem ser obtidas curvas com decaimentos mais lentos e, principalmente, não 

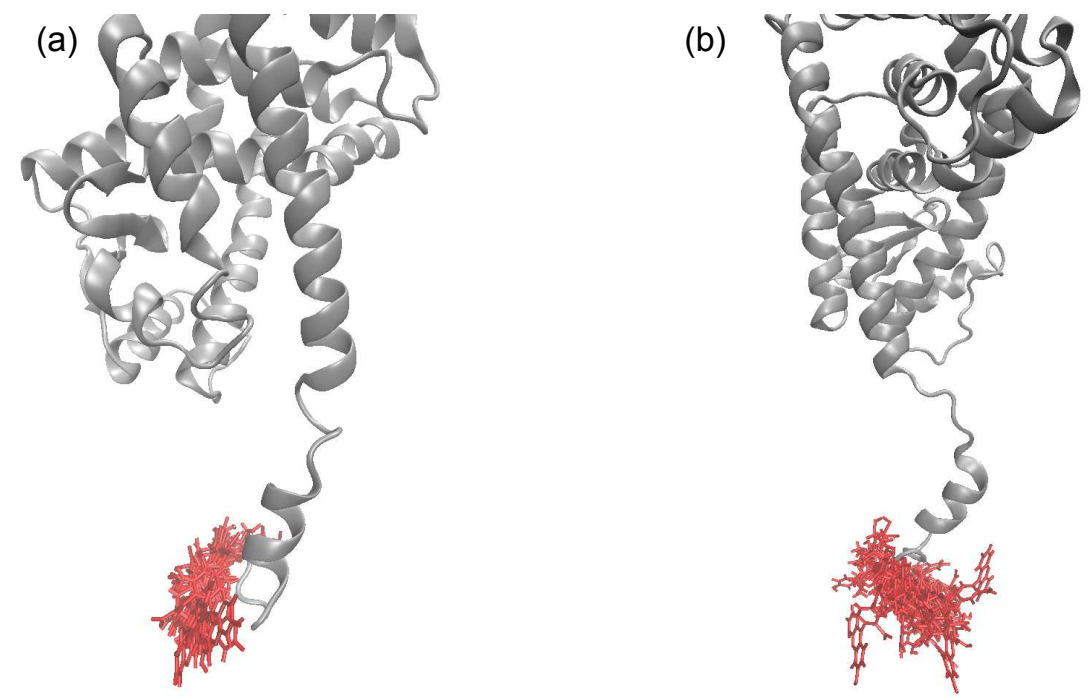

Figura 5.4 - Sobreposição de algumas conformações adotadas pela molécula de cys-fluor na simulação correspondente a curva de anisotropia com o decaimento mais lento (a) e com decaimento mais rápido (b) para o modelo de PPAR com a H12 aberta.

devem ser obtidas curvas com decaimentos que justifiquem as observações experimentais.

Embora o cys-fluor adote uma conformação mais rígida, conferindo um tempo de decaimento maior para a curva de anisotropia dessa simulação, a hélice 12 apresenta um comportamento bastante similar ao observado para as demais simulações para esse modelo. Ao comparar a evolução temporal do RMSD para essa simulação (Simulação 1 da figura [5.5) e para outra associada a uma curva de anisotropia com decaimento mais rápido (Simulação 2 da figura (5.5), observa-se que ambas apresentam desvios significativos em relação a estrutura inicial, mostrando que a hélice 12 é bastante móvel nos dois casos. Portanto, não é a mobilidade da $\mathrm{H} 12$ que afeta o decaimento da anisotropia, mas principalmente a capacidade da sonda de interagir com a proteína. O decaimento mais rápido experimental em apo-PPAR não pode, portanto, ser diretamente interpretado como um reflexo da maior mobilidade da $\mathrm{H} 12$.

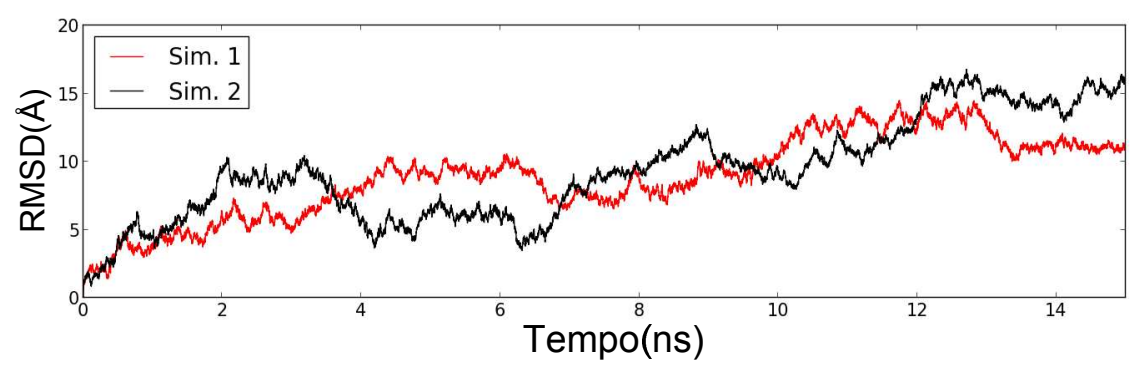

Figura 5.5 - Evolução temporal do RMSD da hélice 12 para as simulações com decaimento mais rápido (vermelho) e mais lento (preto). 


\subsection{Outros modelos de receptores nucleares com hélice 12 aberta}

O modelo de PPAR $\gamma$ com a hélice 12 aberta foi gerado a partir de uma modificação da estrutura cristalográfica. Para complementar o estudo da mobilidade do cys-fluor acoplado a um receptor nuclear que apresenta a hélice 12 estendida em relação ao corpo do LBD, utilizamos também outras duas estruturas obtidas por difração de raios-X. Foram utilizadas as estruturas do Receptor de ácido Retinóico na sua forma apo (1LBD) (14) e do Receptor de Estrógeno (1A52) (56).

(a)

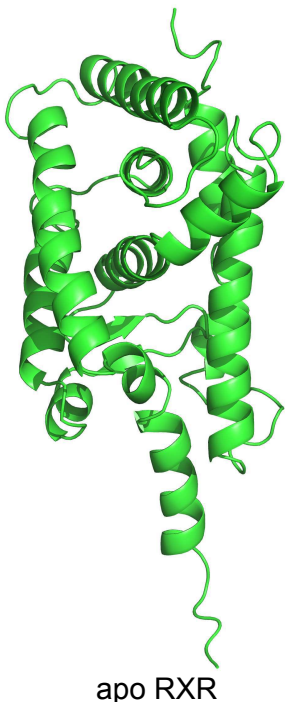

(b)

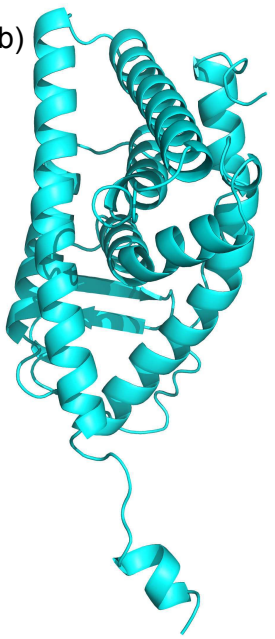

apo ER

Figura 5.6 - Estruturas cristalográficas de receptores nucleares com a hélice 12 aberta utilizados para estudar o decaimento da anisotropia de fluorescência: (a) estrutura do Receptor do Ácido Retinóico (PDB: 1LBD) e (b) estrutura do Receptor de Estrógeno (PDB: 1A52).

A estrutura do Receptor de Ácido Retinóico sem ligante foi a primeira estrutura cristalográfica de receptores nucleares a ser resolvida, juntamente com a estrutura do LBD do holo-RAR. Juntas, essas estruturas motivaram o modelo da ratoeira. A estrutura de ER utilizada também teve sua estrutura cristalográfica determinada em um arranjo simular ao do RXR (H12 aberta). É importante ressaltar que em cristais usados para difração de raios-X, as proteínas estão sujeitas a diversas interações associadas a estabilização do cristal que podem ser diferentes das interações existentes para a proteína em solução. Além disso, o efeito do empacotamento cristalino é ainda mais pronunciado em regiões de maior mobilidade da proteína, como a hélice 12, podendo gerar estruturas diferentes das estruturas nativas. Para a estrutura de ER, foi sugerido que a estrutura obtida com a hélice 12 aberta era um artefato 
do empacotamento cristalino.

Para cada receptor foram construídas 10 configurações inicias e foram realizados os mesmos procedimentos descritos anteriormente, gerando 10 simulações de produção de 20 ns para cada estrutura. A partir dessas simulações, o comportamento do cys-fluor e da hélice 12 foram estudados.

Na figura 5.7 estão mostradas as curvas de anisotropia obtidas para o ER (figura 5.7 (a)) e para o RXR (figura 5.7 (b)). Assim como para o PPAR $\gamma$ com a hélice 12 aberta, as curvas de anisotropia obtidas para as simulações com RXR e ER mostraram curvas com decaimentos rápidos, resultado da rápida dinâmica reorientacional do cys-fluor, que nesses sistemas, se move sem impedimentos estéricos e sem interações persistentes com a superfície do LBD, como ocorre para o holo-PPAR $\gamma$.

(a)

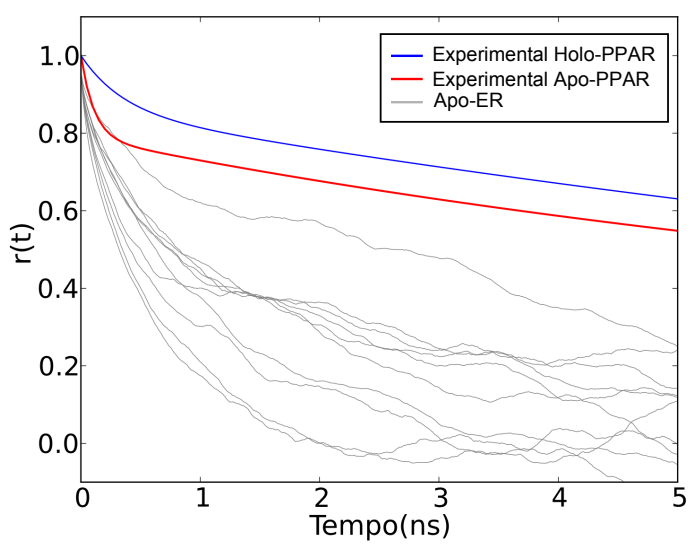

(b)

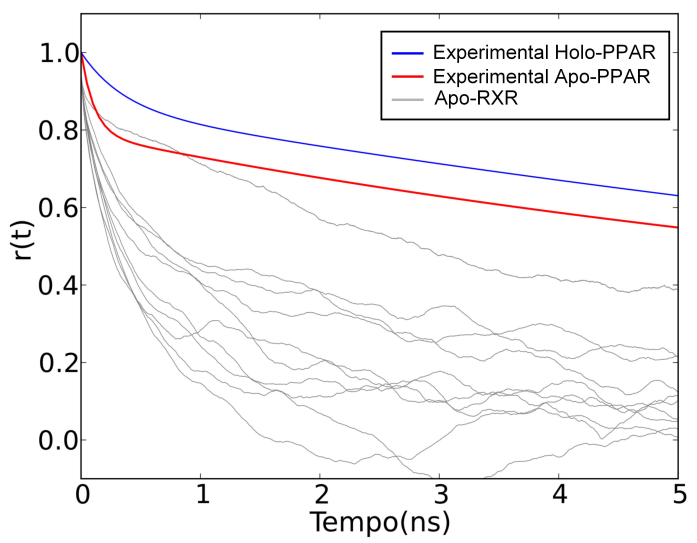

Figura 5.7 - Curvas de anisotropia para o cysfluor acoplado a H12 do ER (a) e do RXR (b).

Na figura 5.7 (b) observa-se a existencia de um curva de anisotropia que apresenta um decaimento significativamente mais lento que as demais. Esse tipo de comportamento não foi observado para as outras estruturas com a H12 aberta. Isso ocorre porque a estrutura do RXR permite que o cys-fluor tenha uma maior interação com o LDB, especialmente com a hélice 12. Na figura 5.8 está mostrada a conformação adotada pela sonda na simulação corresponde à curva de anisotropia com decaimento mais lento. Observa-se que nessa estrutura a sonda é capaz de interagir com a superfície do LBD, conferindo uma dinâmica mais lenta à sonda, o que explica o comportamento da curva de anisotropia. Interações desta forma, foram observadas apenas para essa simulação de RXR, não sendo observada para os demais modelos de receptores nucleares com a H12 aberta. 


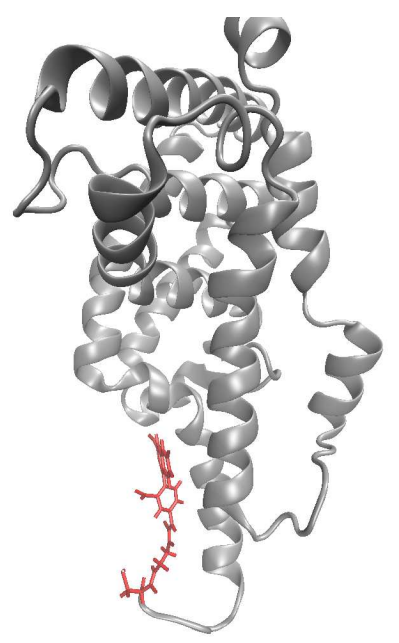

Figura 5.8 - Conformação adotada pelo cys-fluor em uma simulação para RXR onde é possivel a interação da sonda com a superfície do $L B D$, resultando em uma curva de anisotropia com decaimento lento.

\subsection{Mobilidade da hélice 12}

A mobilidade da hélice 12 para as três estruturas com a H12 aberta também foi estudada. Na figura 5.9 estão mostradas os RMSDs médios para cada receptor. Assim como para o PPAR $\gamma$ com a $\mathrm{H} 12$ fechada, foi realizado primeiramente o alinhamento de todos os frames e calculado o RMSD apenas para a hélice 12. Para o PPAR $\gamma$ a hélice 12 foi definida como sendo formada pelos resíduos 465 a 477, para o ER formada pelos resíduos 536 a 544 e para o RXR pelos resíduos 444 a 456. Observa-se que a mobilidade da H12 para os três modelos, como esperado, é mais intensa que para o PPAR $\gamma$ nativo, principalmente para o PPAR $\gamma$ e para o ER, cujas hélices 12 adotam conformações que distam até cerca de $15 \AA$ da conformação inicial. Entretanto, nota-se também que para o RXR, seu RMSD apresenta uma menor flutuação no tempo, indicando que a hélice 12 desse receptor é a menos móvel dentre os três modelos de receptores com a hélice 12 aberta. Provavelmente, essa menor mobilidade, também observada na curva de anisotropia, é devido o fato das hélices $\mathrm{H} 11$ e $\mathrm{H} 12$ serem unidas, resultando em uma estrutura mais rígida que as demais. Porém, mesmo sendo mais rígida, as flutuações estruturais são mais intensas que as obtidas para o holo-PPAR $\gamma$

Na figura 5.10 estão mostradas as conformações mais divergentes adotas pela $\mathrm{H} 12$ de cada modelo. Nota-se para o PPAR $\gamma$ e para o ER a variação conformacional sofrida pela hélice 12 é bastante intensa se comparada com as variações observadas para o PPAR $\gamma$ nativo. Já para o RXR a alteração na conformação é menos dramática, porém, ainda assim, o decaimento da anisotropia é, para o cys-fluor ligado à $\mathrm{H} 12$ do apo-RXR, muito mais rápido que as curvas 


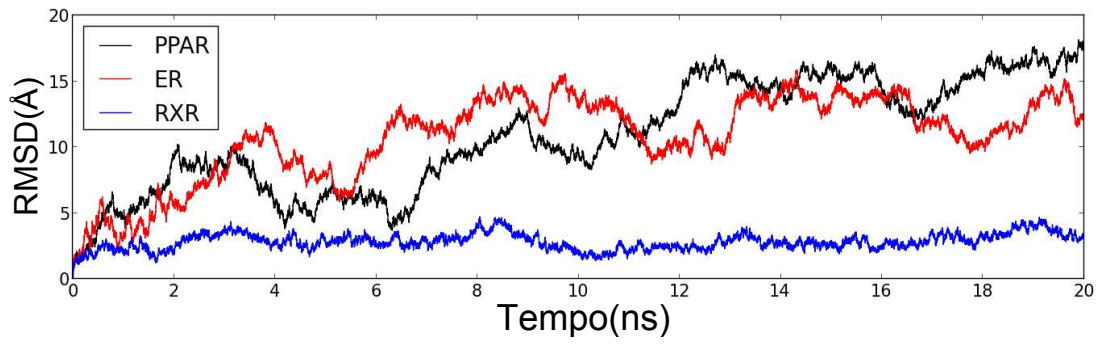

Figura 5.9 - Evolução temporal do RMSD da hélice 12 em relação a posição inicial para os modelos com a H12 aberta.

experimentais de apo-PPAR $\gamma$. Isto reforça o fato de que o decaimento rápido da anisotropia está associado à liberdade conformacional da sonda e sua capacidade de interagir com a proteína. Portanto, o decaimento experimental relativamente lento de apo-PPAR $\gamma$ depende necessariamente da interação da sonda com o corpo da proteína implicando em uma estrutura com a H12 fechada.

(a)

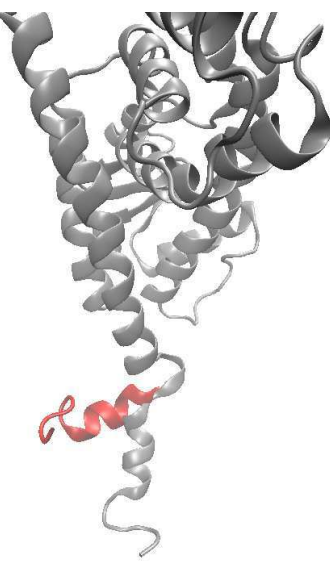

PPAR $\gamma$ (b)

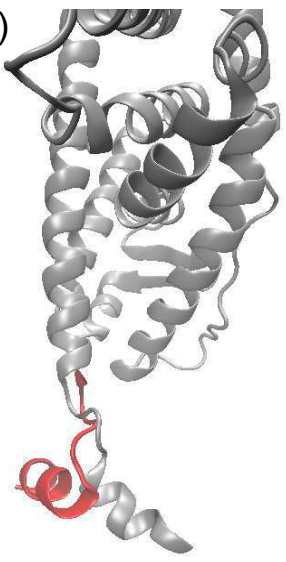

ER (c)

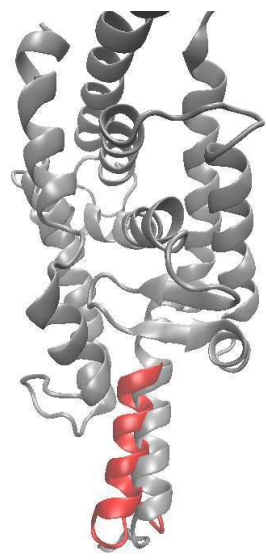

RXR

Figura 5.10 - Máxima variação conformacional sofrida pela hélice 12 do PPAR (a), ER (b) e RXR (c).

Embora acredita-se que a estrutura do RXR com a H12 estendida possa ser interpretada como resultado de artefatos cristalográficos, é importante lembrar é possível que o LBD desse receptor exiba um equilíbrio conformacional diferente dos demais receptores. Por possuir as hélices $\mathrm{H} 11$ e H12 separadas por um número menor de aminoácidos em comparação com os demais receptores, a H12 do RXR pode apresentar uma flexibilidade conformacional limitada, resultando na estrutura com a hélice aberta. Experimentos de anisotropia de fluorescência com comparação direta com nossos resultados forneceriam uma resposta definitiva para a mobilidade do LBD do RXR. 


\subsection{Conclusões}

Com o objetivo de verificar o comportamento da dinâmica reorientacional do cys-fluor acoplado à estruturas onde a hélice 12 adota uma conformação estendida em relação ao corpo do LBD, realizamos simulações para o calculo da anisotropia em função do tempo para quatro modelos de receptores nucleares com a H12 aberta. Para todos os casos, as taxas de decaimento se mostraram muito maiores que as observadas experimentalmente. Assim, as observações experimentais não podem ser explicadas pela dinâmica reorientacional do cys-fluor acoplado às estruturas com a $\mathrm{H} 12$ aberta.

Esses resultados mostram que as observações experimentais estão associadas a pequenas variações conformacionais da hélice 12 , sem envolver o deslocamento desta da superfície do LBD, já que estruturas com a H12 aberta geraram curvas de anisotropia incapazes de explicar o comportamento experimental. Além disso, sugerem que para a regulação dos receptores nucleares, ou seja, para a entrada e saída de ligantes e para a interação com proteínas coativadoras, são requeridas pequenas flutuações da hélice 12 em torno a conformação ativa. Dessa forma, esse trabalho vem reforçar a imagem de um domínio de ligação com o ligante assumindo uma conformação "empacotada", ou seja, com a H12 sempre interagindo com a superfície do LBD além de fornecer evidências da amplitude das mudanças conformacionais que a $\mathrm{H} 12$ pode sofrer. 


\section{CAPÍTULO 6}

\section{Conclusões finais}

Receptores nucleares formam uma superfamília de proteínas responsável pela regulação da expressão gênica em eucariotos, cuja atividade é controlada pela interação de pequenas moléculas com o domínio de ligação com o ligante. As primeiras estruturas cristalográficas de receptores nucleares (apo-RXR e holo-RAR) sugeriram que a associação de um ligante ao LBD seria responsável por uma mudança conformacional bastante dramática, principalmente na hélice 12. Esta, na ausência de ligante adotaria uma conformação estendida em relação ao corpo do LBD, deixando o sítio de ligação exposto e permitindo a entrada do ligante, enquanto que na presença do ligante, adotaria uma conformação ativa, presa a superfície do LDB. Dessa forma, a conformação e mobilidade da hélice 12 foram tidas como determinantes para a ativação e desativação do mecanismo de transcrição. Embora estudos anteriores mostrem a estabilização da hélice 12 na presença de agonista, ainda não havia sido construído um modelo molecular capaz de dimensionar o tamanho da variação conformacional sofrida pela hélice C-terminal tanto na presença quanto na ausência de ligantes.

Os resultados presentes nesse trabalho fornecem um modelo para a dimensão dessa variação conformacional. As simulações de cys-fluor acoplado à hélice 12 do holo-PPAR $\gamma$ mostraram que o comportamento da sonda em solução é bastante variado, dando como resposta tempos de decaimento para anisotropia variáveis de acordo com a conformação inicial adotada pela sonda. Entretanto, ao comparar os resultados experimentais obtidos por Schwabe, observa-se tanto para PPAR $\gamma$ na presença ou na ausência de ligante, as curvas experimentais assemelham-se apenas às curvas teóricas com decaimentos lentos. Isso significa que apenas simulações nas quais a sonda e a hélice 12 apresentam mobilidades reduzidas são capazes de explicar os resultados obtidos experimentalmente.

Ao observar o comportamento da hélice 12 nas simulações correspondentes às curvas de anisotropia com maior e menor decaimento, notou-se que mesmo para a simulação onde a hélice 12 apresenta maior alteração conformacional, essa variação não ultrapassa 3,5 $\mathrm{da}$ estrutura inicial. Já para a simulação associada ao maior tempo de decaimento, a variação 
conformacional é mínima. Uma vez que os resultados experimentais apresentam comportamentos intermediários, espera-se que em solução a mobilidade da hélice 12 , tanto na presença quanto na ausência de ligantes, seja também bastante reduzida.

Uma vez que não existem estruturas cristalográficas de apo-PPAR $\gamma$ com a hélice 12 estendida (conformação sugerida pelo modelo da ratoeira), utilizamos simulações de SMD para construir tal modelo. As curvas de anisotropia obtidas para esse modelo revelaram tempos de decaimentos muito menores que os observados experimentalmente. Outros dois modelos de receptores nucleares com a $\mathrm{H} 12$ aberta mostraram o mesmo comportamento: curva de anisotropia com decaimentos acentuados. Uma vez que os resultados experimentais não podem ser explicados pela dinâmica conformacional do cys-fluor acoplado ao PPAR $\gamma$ com a H12 aberta, é possível concluir que a hélice 12 deve permanecer acoplada a superfície do LBD em solução e que se existentes, conformações com a H12 estendidas devem ser raras.

Acreditamos que esse trabalho tenha fornecido um modelo definitivo capaz de dimensionar a mobilidade da hélice 12 em solução. Esses resultados não contradizem o conceito, bem estabelecido, de que na ausência de ligante a hélice 12 é mais móvel, mas revelam que tanto na presença quanto na ausência de ligante a H12 sofre apenas pequenas alterações locais, não envolvendo o total deslocamento em relação ao corpo do LBD. Este modelo está de acordo com resultados anteriores de simulações de dinâmica molecular e experimentos de troca hidrogênio/deutério e, além disso, são consistentes com os mecanismos de associação e dissociação de ligantes e recrutamento de proteínas correguladoras.

Embora nesse trabalho apenas simulações de holo-PPAR $\gamma$ e de receptores com a hélice 12 aberta tenham sido realizadas, a comparação dessas simulações com a curva experimental de apo-PPAR $\gamma$ ajudou na construção de um modelo para a mobilidade desse receptor na ausência de ligantes. Posteriormente, para complementar o trabalho já realizado, pretende-se a realização de simulações de apo-PPAR $\gamma$ para construção de um modelo mais detalhado da mobilidade da H12 nessas condições e o cálculo da energia livre associada às possíveis conformações de hélice 12. Porém, desde já, espera-se que a variação conformacional seja reduzida, como sugerido pelos nossos resultados. 


\section{REFERÊNCIAS}

1 BAIN, D. L.; HENEGHAN, A. F.; JONES, K. D. C.; MIURA, M. T. Nuclear receptor strcuture: implications for functions. Annual Review of Physiology, v. 67, p. 201 - 219, 2007. DOI: 10.1146/annurev.physiol.69.031905.160308

2 GRONEMEYER, H.; GUSTAFSSON, J. A.; LAUDET, V. Principles for the modulation of the nuclear receptor superfamily. Nature Reviews Drug Discovery, v. 3 , n. 11, p. 950 - 964 , 2004.

3 LI, Y.; LAMBERT, M. H.; XU, H. E. Activation of nuclear receptors: a perspective from structural genomics. Structure, v. 11, n. 7, p. 741 - 746, 2003.

4 ARANDA, A.; PASCUAL, A. Nuclear hormone receptor and gene expression. Physiological Reviews, v. 81, n. 3, p. 1269 - 1304, 2001.

5 RIBEIRO, R. C. J.; KUSHNER, P. J.; BAXTER, J. D. The nuclear hormone receptor gene superfamily. Annual Review of Medicine, v. 46, p. 443 - 453, 1995. DOI: 10.1146/annurev.med.46.1.443

6 SCHWABE, J. W. R.; CHAPMAN, L.; FINCH, J. T.; RHODES, D. The crystal structure of the estrogen receptor DNA-binding domain bound to DNA: how receptors discriminate between their response elements. Cell, v. 75, n. 3, p. $567-578,1993$.

7 KHORASANIZADEH, S.; RASTINEJAD, F. Nuclear-receptor interactions on DNAresponse elements. Trends in Biochemical Sciences, v. 26, n. 6, p. 384 - 390, 2001.

8 EGEA, P. F.; MITSCHLER, A.; ROCHEL, N.; RUFF, M.; CHAMBON, P.; MORAS, D. Crystal structure of the human $\operatorname{RXR} \alpha$ ligand-binding domain bound to its natural ligand: 9-cis retinoic acid. The EMBO Journal, v. 19, n. 11, p. 2592 - 2601, 2000.

9 MICHALIK, L. et al. International union of pharmacology. LXI. Peroxisome proliferatoractived receptors. Phamacological Reviews, v. 58, n. 4, p. 726 - 741, 2006.

10 NAGY, L.; SCHWABE, J. W. R. Mechanism of the nuclear receptor molecular switch. Trends in Biochemical Sciences, v. 29, n. 6, p. 317 - 324, 2004. 
$11 \mathrm{XU}, \mathrm{H}$. E. et al. Structural determinants of ligand binding selectivity between the peroxisome proliferator-activated receptors. Proceedings of the National Academy of Sciences, v. 98, n. 24, p. 13919 - 13924, 2001.

$12 \mathrm{XU}, \mathrm{H}$. E. et al. Structural basis for antagonist-mediated recruitment of nuclear corepressors by PPAR $\alpha$. Nature, v. 415, n. 6873, p. 813 - 817, 2002.

13 RENAUD, J. P; ROCHEL, N.; RUFF, M.; VIVAT, V.; CHAMBON, P.; GRONEMEYER, $\mathrm{H}$.; MORAS, D. Crystal structure of the RAR $\gamma$ ligand-binding domain bound to all-trans retinoic acid. Nature, v. 378, p. 681 - 689, 1995. DOI:10.1038/378681a0

14 BOURGUET, W.; RUFF, M.; CHAMBON, P.; GRONEMEYER, H.; MORAS, D. Crystal structure of the ligand-binding domain of the human nuclear receptor RXR $\alpha$. Nature, v. 375, p. 377 - 382, 1995. DOI:10.1038/375377a0

15 NETTLES, K. W.; GREENE, G. L. Ligand control of coregulator recruitment to nuclear receptors. Annual Review of Physiology, v. 67, p. 309 - 333, 2005. DOI: 10.1146/annurev.physiol.66.032802.154710

16 MORAS, D.; GRONEMEYER, H. The nuclear receptor ligand-binding domain:structure and function. Current Opinion in Cell Biology, v. 10, n.3, p. 384 - 391, 1998.

17 WANG, Y.; CHIRGADZE, N. Y.; BRIGGS, S. L.; KHAN, S.; JENSEN, E. V.; BURRIS, T.P. A second binding site for the hydroxytamoxifen within the coactivator-binding groove of estrogen receptor $\beta$. Proceedings of the National Academy of Science of the United States of America, v. 103 , n. 26, p. 9908 - 9911, 2006.

18 NOLTE, R. T.; WISELY, G. B.; WESTIN, S.; COBB, J. E.; LAMBERT, M. H.; KUROKAWA, R.; ROSENFELD, M.; WILLSON, T. M.; GLASS, C. K.; MILBURN, M. Ligand binding and co-activator assembly of the peroxisome proliferator-actived receptor- $\gamma$. Nature, v. 395 , p. $137-143,1998$. DOI:10.1038/25931

19 FIGUEIRA, A. C. M.; SAIDEMBERG, D. M.; SOUZA, P. C. T.; MARTÍNEZ, L.; SCANLAN, T. S.; BAXTER, J. D.; SKAF, M. S.; PALMA, M. S.; WEBB, P.; POLIKARPOV, I. Analysis of agonist and antagonist effects on thyroid hormone receptor conformation by hydrogen/deuterium exchange. Molecular Endocrinology, v. 25, n. 1, p. 15 - 31, 2011.

20 MARTINEZ, L.; POLIKARPOV, I.; SKAF, M. S. Only subtle protein conformational adaptations are require for ligand binding to thyroid hormone receptors: simulations using a novel multipoint steered molecular dynamics approach. The Journal of Physical Chemistry B, v. 112 , n. 34, p. $10741-10751,2008$.

21 MARTINEZ, L.; WEBB, P.; POLIKARPOV, I.; SKAF, M. S. Molecular dynamics simulations of ligand dissociation fron thyroid hormone receptors: evidence of the likeliest escape pathway and its implications for the design of novel ligands. Journal of Medicinal Chemistry, v. 49, n. 1, p. $23-26,2006$. 
22 BLONDEL, A.; RENAUD, J. P.; FISCHER, S.; MORAS, D.; KARPLUS, M. Retinoic acid receptor: a simulation analysis of retinoic acid binding and the resulting conformational changes. Journal of Molecular Biology, v. 291, n. 1, p. 101-115, 1999.

23 KOSZTIN, D.; IZRAILEV, S.; SCHULTEN, K. Unbinding of retinoic acid from its receptor studied by steered molecular dynamics. Biophysical Journal, v. 76, p. 188-197, 1999. DOI: 10.1016/S0006-3495(99)77188-2

24 MARTINEZ, L.; SONODA, M. T.; WEBB, P.; BAXTER, J. D.; SKAF, M. S.; POLIKARPOV, I. Molecular dynamics simulations reveal multiple pathways of ligand dissociation from thyroid hormone receptors. Biophysical Journal, v. 89 , n. 3, p. $2011-$ 2023, 2005.

25 TONTONOZ, P.; SPIEGELMAN, M. Fat and beyond: the diverse biology of PPAR $\gamma$. Annual Review of Biochemistry, v. 77 , p. 289 - 312, 2008. DOI: 10.1146/annurev.biochem.77.061307.091829

26 ZOETE, V.; GROSDIDIER, A.; MICHIELIN, O. Peroxisome proliferator-actived receptor structures: ligand specificity, molecular switch and interactions with regulators. Biochimica et Biophysica Acta, v. 1771 , n. 8, p. 915 - 925, 2007.

27 LEHRKE, M.; LAZAR, M. The many faces of PPAR $\gamma$. Cell, v. 123 , n. 6, p. 993 - 999, 2005.

28 CHANDRA, V.; HUANG, P.; HAMURO, Y.; RAGHURAM, S.; WANG, Y.; BURRIS, T.; RASTINEJAD, F. Structure of the intact PPAR- $\gamma$-RXR- $\alpha$ nuclear receptor complex on DNA. Nature, v. 456 , n. 7220, p. $350-356,2008$.

29 GAMPE, R. T. et al. Assymetry in the PPAR $\gamma / \mathrm{RXR} \alpha$ crystal structure reveals the molecular basis of heterodimerization among nuclear receptors. Molecular Cell, v. 5, n. 3, p. 545 $555,2000$.

30 BRUNNING, J. B.; CHALMERS, M. J.; PRASAD, S.; BUSBY, S. A.; KAMENECKA, T. M.; HE, Y.; NETTLES, K. W.; GRIFFIN, P. R. Partial agonists activate PPAR $\gamma$ using a helix 12 independent mechanism. Structure, v. 15, p. 1258-1271, 2007. DOI 10.1016/j.str.2007.07.014

31 WAKU, T.; SHIRAKI, T.; OYAMA, T.; MAEBARA, K.; NAKAMORI, R.; MORIKAWA, $\mathrm{K}$. The nuclear receptor PPAR $\gamma$ individually responds to serotonin and fatty acid-metabolites. The EMBO Journal, v. 29, n. 19, p. 3395 - 3407, 2010.

$32 \mathrm{CHOI}, \mathrm{J}$. H. et al. Anti-diabetic drugs inhibit obesity-linked phosphorylation of PPAR $\gamma$ by Cdk5. Nature, v. 466, n. 7305, p. 451 - 456, 2010.

33 MONTANARI, R. et al. Crystal structure of the peroxisome proliferator-actived receptor $\gamma(\operatorname{PPAR} \gamma)$ ligand binding domain complexed with a novel partial agonist: a new region of the hydrophobic pocket could be exploited for drug design. Journal of Medicinal Chemistry, v. 51, n. 24, p. $7768-7776,2008$. 
34 OBERFIELD, J. L. et al. A peroxisome proliferator-actived receptor $\gamma$ ligand inhibits adipocyte differentiation. Proceedings of the National Academy of Sciences of the United States of America, v. 96, n. 11, p. 6102 - 6106, 1999.

35 MOLNÁR, F.; MATILAINEN, M.; CARLBERG, C. Structural determinants of the agonistindependent association of human peroxisome proliferator-actived receptors with coactivators. The Journal of Biological Chemistry, v. 280, n. 28, p. 26543 - 26556, 2005.

36 JOHNSON, B. A.; WILSON, E. M.; LI, Y.; MOLLER, D. E.; SMITH, R. G.; ZHOU, G. Ligand-induced stabilization of PPAR $\gamma$ monitored by NMR spectroscopy: implications for nuclear receptor activation. Journal of Molecular Biology, v. 298 , n. 2, p. 187 - 194, 2000.

37 KAllenberger, B. C.; LOVE, J. D.; ChATTERJEE, V. K. K.; SCHWABE, J. W. R. A dynamic mechanism of nuclear receptor activation and its perturbation in human disease. Nature Structural Biology, v. 10 , n. 2, p. 136 - 140, 2003.

38 HAMURO, Y. et al. Hydrogen/deuterium-exchange (H/D-Ex) of PPAR $\gamma$ LBD in the presence of various modulators. Protein Science, v. 15, n. 8, p. 1883 - 1892, 2006.

39 KARPLUS, M.; KURIYAN, J. Molecular dynamics and protein function. Proceedings of the National Academy of Science, v. 102, n. 19, p. 6679 - 6685, 2005.

40 MCCAMMON, J. A.; GELIN, B. R.; KARPLUS, M. Dynamics of folded proteins. Nature, v. 267, n. 7220 , p. $585-590,1997$.

41 KARPLUS, M.; MCCAMMON, J. A. Molecular dynamics simulations of biomolecules. Nature Structural biology, v. 9, n. 9, p. 646 - 652, 2002.

42 MACKERELL, A. D et al. All-atom empirical potential for molecular modeling and dynamics studies of proteins. Journal of Physical Chemistry B, v. 102 , n. 18 , p. $3586-3616$, 1997.

43 BROOKS, B. R. et al. CHARMM:A program for macromolecular energy, minimization and dynamics calculations. Journal of Computational Chemistry, v. 4, n. 2, p. 187- 217, 1983.

44 JORGENSEN, W. L.; MAXWELL, D. S.; TIRADO-RIVES, J. Development and testing of the OPLS all-atom force field on conformational energetics and propoerties of organic liquids. Journal of the American Chemical Society, v. 118 , n. 45, p. 11225 - 11236, 1996.

45 WEINER, S. J. et al. A new force field for molecular mechanical simulation of nucleic acids and proteins. Journal of the American Chemical Society, v. 106 , n. 3, p. $765-784,1984$.

46 HeRmans, J.; BerendSen, H. J. C.; VAN GUNSTEREN, W. F.; POSTNA, J. P. M. A consistent empirical potential for water-protein interactions. Biopolymers, v. 23 , n. 8 , p. 1513 - 1518, 1984. 
47 LEACH, A. R. Molecular modelling: principles and applications. 2nd. ed. Harlow: Prentice Hall, 2001.

48 SCHLICK, T. Molecular modelling and simulations: an interdisciplinary guide. New York: Springer, 2002.

49 PHILLIPS, J. C. et al. Scalable molecular dynamics with NAMD. Journal of Computational Chemistry, v. 26 , n. 16 , p. $1781-1802,2005$.

50 SCHRODER, G. F.; ALEXIEV, U.; GRUBMULLER, H. Simulation of fluorescence anisotropy experiments: probing protein dynamics. Biophysical Journal, v. 89 , n. 6 , p. 3757 3770, 2005.

51 ICHIYE, T.; KARPLUS, M. Fluorescence depolarization of tryptophan residues in proteins: a molecular dynamics study. American Chemical Society, v. 22 , n. 12 , p. 2884 - 2893, 1983.

52 MARK, P.; NILSSON, L. Structure and dynamics of the TIP3P, SPC and SPC/E water models at 298 K. The Journal of Physical Chemistry A, v. 105 , n. 43 , p. 9954 - 9960, 2001.

53 DOSHI, U.; HAMELBERG, D. Extracting realistic kinetics of rare activated processes from accelerated molecular dynamics using Kramers' theory. Journal of Chemical Theory and Computation, v. 7, n.3, p. 575 - 581, 2011.

54 MILLS, R. Self-diffusion in normal and heavy water in the range 1-45.deg. Journal of Physical Chemistry, v. 77 , n. 5, p. 685 - 688, 1973.

55 MARTÍNEZ, L.; ANDRADE, R.; BIRGIN, E. G.; MARTÍNEZ, J. M. Packmol: a package for building initial configurations for molecular dynamics simulations. Journal of Computational Chemistry, v. 30, n.13 p. 2157 - 2164, 2009.

56 TANEMBAUM, D. M.; WANG, Y.; WILLIAMS, S. P.; SIGLER, P. B. Crystallographic comparison of the estrogen and progesterone receptor's ligand binding domains. Proceedings of the National Academy of Science, v. 95, n. 11 , p. 5998 - 6003, 1998.

57 MARK, P.; NILSSON, L. A molecular dynamics study of tryptophan in water. The Journal of Physical Chemistry B, v. 106 , n. 36 , p. 9440 - 9445, 2002.

58 DAURA, X.; SUTER, R.; VAN GUNSTEREN, W. F. Validation of molecular simulation by comparison with experiment: rotarional reorientation of tryptophan in water. The Journal of Chemical Physics, v. 110 , n. 6 , p. $3049-3055,1999$. 